\title{
AVALIAÇÃO DA PRESENÇA DE CIANOBACTÉRIAS EM EFLUENTES DE SISTEMA DE TRATAMENTO DE ESGOTOS SANITÁRIOS POR LAGOAS DE ESTABILIZAÇÃO ASSOCIADAS A TRATAMENTO FÍSICO-QUÍMICO
}

\author{
Dissertação apresentada à Escola \\ Politécnica de Engenharia da \\ Universidade de São Paulo para obtenção \\ do título de mestre em Engenharia \\ Hidráulica e Sanitária.
}




\title{
AVALIAÇÃO DA PRESENÇA DE CIANOBACTÉRIAS EM EFLUENTES DE SISTEMA DE TRATAMENTO DE ESGOTOS SANITÁRIOS POR LAGOAS DE ESTABILIZAÇÃO ASSOCIADAS A TRATAMENTO FÍSICO-QUÍMICO
}

\author{
Dissertação apresentada à Escola \\ Politécnica de Engenharia da \\ Universidade de São Paulo para obtenção \\ do título de mestre em Engenharia \\ Hidráulica e Sanitária. \\ Área de concentração: \\ Saneamento Básico \\ Orientador: Prof. Dr. Roque Passos Pivelli
}


Este exemplar foi revisado e alterado em relação à versão original, sob responsabilidade única do autor e com a anuência de seu orientador.

São Paulo, 26 de outubro de 2007.

Assinatura do autor

Assinatura do orientador

Godoy, Osvaldo Americano

Avaliação da presença de cianobactérias em efluentes de sistema de tratamento de esgotos sanitários por lagoas de estabilização associadas a tratamento físico-químico / O.A. Godoy. -São Paulo, 2007.

131 p. FICHA CATALOGRÁFICA

Dissertação (Mestrado) - Escola Politécnica da Universidade de São Paulo. Departamento de Engenharia Hidráulica e Sanitária.

1.Tratamento de esgotos sanitários 2.Cyanophyta 3.Lagoas de estabilização I.Universidade de São Paulo. Escola

Politécnica. Departamento de Engenharia Hidráulica e Sanitária II.t. 
Aos meu amado pai, Osvaldb Godoy Ventaja e minha amada mãeZZul ekkeAmericano Godoy, quesempreforam meus maicres em hores exemplos comon pessoes, a minha arada esposa Lucia que sempre demenstrou apcio e paciênia nesta jomada de estudb e durante tocba a nossa vidajuntos eminha anada filha Mariana queéa luz do meu caminho e que entre tantos autros é meu grandeamor edegia navida. 


\section{AGRADECIMENTOS}

A Deus e ao nosso Senhor Jesus Cristo, que nos guia e nos dá força nesta vida.

Ao Profo Dr. Roque Passos Pivelli, pela confiança, paciência, ensinamentos e contribuições para este trabalho.

Aos meus amigos pessoais e também colegas de trabalho Daniel Ribeiro e Luizmar, pelo incentivo, sugestões, conselhos, colaboração e parceria no dia a dia.

Aos especiais colegas e funcionários do Laboratório de Controle Ambiental da Riviera de são Lourenço, Denise, Daniela, Flavia, Elisângela, Anílton e Eduardo, sem ajuda deles este trabalho não seria possível.

Aos colegas da turma de mestrandos de 2004 da Poli, Luciano, Ruy, Lucia, Aline, Érika, Manuel, Hilton, Carlos, Max, Gilberto e Ari, pelo companheirismo ao longo do curso.

A meus amigos de trabalho Daniel Silveira, Fernando, Zenilde e Camilo, pelo incentivo e companheirismo no dia a dia.

A Associação Amigos da Riviera de São Lourenço, SOBLOCO construtora S/A, Cia. Fazendas Acaraú e Praias Paulistas S/A, em permitir a realização deste trabalho.

Aos Amigos de trabalho Paulo Nobre e Luis Nobre pelas sugestões e colaboração.

A minha amada irmã Christiane meu cunhado Edson e meus amados sobrinhos Arthur, Victor e Heitor, pelo carinho, incentivo e momentos de felicidade.

Ao meu sogro Anacleto, meus cunhados Ana Claudia e Paulo Sergio e minha querida sobrinha Maria Clara, pela consideração e carinho ao longo dos anos.

Aos meus grandes amigos André Massa, Roberto, Jorge, Aaron, Thiago e Fabio, pela prazerosa convivência, apoio nos momentos difíceis e muitas risadas.

A todos os meus tios e primos, pelo carinho que sempre demonstraram e que mesmo a distancia não apaga. 


\section{RESUMO}

GODOY, O. A. Avaliação da presença de Cianobactérias em efluentes de sistemas de tratamento de esgotos sanitários por lagoas de estabilização associadas a tratamento físico-químico. 2007. 166f. Dissertação (Mestrado) Escola Politécnica, Universidade de São Paulo,2007.

A presente pesquisa propôs avaliar a presença de cianobactérias, tanto quantitativamente como qualitativamente e clorofila-a quantitativamente, em relação à legislação CONAMA № 357/05, em um sistema de tratamento de lagoas de estabilização com pré e pós-tratamento físico-químico, além de avaliar o comportamento de parâmetros convencionais, como Demanda Bioquímica de Oxigênio (DBO), Demanda Química de Oxigênio (DQO), Nitrogênio amoniacal (N$\mathrm{NH}_{3}$ ), Fósforo (P), Sólidos Suspensos Totais (SST), Potencial Hidrogeniônico $(\mathrm{pH})$. Para tanto, utilizou-se a Estação de Tratamento de Efluentes da Riviera de São Lourenço - Bertioga - SP, para o estudo em questão, onde o sistema é composto de Tratamento primário quimicamente assistido (TPQA) com aplicação de produtos químicos (polímero como coagulante), seguido de duas lagoas facultativas, lagoa de maturação, Decantador de algas (decantador) com aplicação de produtos químicos (polímero e cal hidratada) e tanque de contato de cloro.

Utilizou-se um período de estudo de nove meses (Outubro/2005 à Junho/2006), com coletas e análises semanais e quinzenais, dos efluentes das lagoas facultativas, da lagoa de maturação, do Decantador de algas e final do sistema.

As análises foram realizadas no Laboratório de Controle Ambiental da Riviera de São Lourenço. Foram encontradas ao longo do sistema as seguintes espécies de cianobactérias: Planktothrix sp, Merismopedia sp, Microcystis sp, Phormidium sp, Chroococcus sp, Pseudonabaena sp, Aphanocapsa sp. Ao longo de todo o período, as maiores presenças de espécies foram de Planktothrix sp. e Merismopedia sp.

Encontrou-se os seguintes valores ao longo do sistema para densidades de cianobactérias na baixa temporada: para lagoas facultativas - $18880 \mathrm{cel} / \mathrm{mL}$; lagoa de maturação - $16350 \mathrm{cel} / \mathrm{mL}$; Decantador de algas - $4680 \mathrm{cel} / \mathrm{mL}$; saída do sistema - $6400 \mathrm{cel} / \mathrm{mL}$; e na alta temporada: para lagoas facultativas - $26340 \mathrm{cel} / \mathrm{mL}$; lagoa de maturação - $13170 \mathrm{cel} / \mathrm{mL}$; Decantador de algas - $11840 \mathrm{cel} / \mathrm{mL}$; saída do 
sistema - $2910 \mathrm{cel} / \mathrm{mL}$. As densidades de cianobactérias encontradas na baixa e alta temporada na saída do tratamento refletem valores sempre abaixo em relação à nova legislação CONAMA № 357/05 no que tange os limites de cianobactérias para águas classes I, II e III.

As concentrações de clorofila-a no efluente da lagoa de maturação resultaram em $432 \pm 182 \mu \mathrm{g} / \mathrm{L}$, e $268 \pm 185 \mu \mathrm{g} / \mathrm{L}$ no efluente final do sistema. A eficiência de remoção foi de $53 \pm 28 \%$. Estes resultados de clorofila-a para este sistema de tratamento de esgotos com as novas mudanças, ou seja, o sistema biológico precedido e sucedido por tratamento físico-químico, podem ser considerados satisfatórios, mas são mais elevados que os limites preconizados na Resolução CONAMA № 357/05 para águas classes I, II e III, havendo a necessidade se contar com algum grau de diluição para permitir o enquadramento.

Para os parâmetros convencionais analisados ao longo do período, destacam-se as concentrações no efluente final de fósforo de $5 \pm 2 \mathrm{mgP} / \mathrm{L}$ e de nitrogênio amoniacal de $22 \pm 10 \mathrm{mgN} / \mathrm{L}$. Com relação ao fósforo, observa-se a necessidade de diluição no corpo receptor para o enquadramento às classes mais restritivas e, com relação ao nitrogênio amoniacal, verifica-se que o valor médio é superior ao padrão de lançamento de 20 mgN/L estabelecido pela Resolução 357/2005 do CONAMA.

Palavras - chave: lagoas de estabilização - tratamento físico-químico, cianobactérias - clorofila-a 


\section{ABSTRACT}

GODOY, O. A. Evaluation of the presence of cyanobacteria in wastewater treatment system throught stabilization ponds associated with physicochemical treatment. 2007. 166f. thesis (Master's) - Escola Politécnica, Universidade de São Paulo, São Paulo,2007.

The present research proposes to evaluate the presence of cyanobacteria either quantitatively and qualitatively, as well as chlorophyll-a quantitatively, according to CONAMA № 357/05 legislation, for a stabilization ponds treatment system associated with physico-chemical treatment, as well as evaluating typical parameters behavior, such as Biochemical Oxygen Demand (BOD), Chemical Oxygen Demand (COD), Nitrogen (N), Phosphorus (P), Total Suspended Solids (TSS), power hydrogen $(\mathrm{pH})$.

For the research, It has been used the Riviera de São Lourenço effluent treatment station in Bertioga - SP, where the system includes an Chemical enhanced Primary Treatment (CEPT) with application of chemicals products (polymer with coagulant), followed by two Facultative ponds, maturation pond, Algae Removal (decanter) with application of chemical components (polymer and hydrated lime) and chlorine chicane.

It has taken a period of 9 months (oct/2005 to jun/2006), with both weekly and fortnight sample and analysis, and the observed spots were the facultative pond output, maturation pond output, algae remover output and system output.

The analyses were made by Riviera de São Lourenço environmental control laboratory, when the following sorts of cyanobacteries have been found: Planktothrix $s p$, Merismopedia sp, Microcystis sp, Phormidium sp, Chroococcus $s p$, Pseudonabaena sp, Aphanocapsa sp.

During the whole period, the major presence of species detected were Planktothrix sp.(100\%) and Merismopedia sp.(71\%).

The following values for cyanobacteria density were found at low season: facultative ponds - $18880 \mathrm{cel} / \mathrm{mL}$; maturation pond - $16350 \mathrm{cel} / \mathrm{mL}$; algae removal - 4680 $\mathrm{cel} / \mathrm{mL}$; system output $-2910 \mathrm{cel} / \mathrm{mL}$. The cyanobacdteria density found during low 
and high season at the system output always under the new legislation CONAMA № 357/05, according the cyanobacteria limits for I, II and III classes of water.

The chlorophyll-a concentration on the maturation pond's effluent and system output showed $432 \pm 182 \mu \mathrm{g} / \mathrm{L}$ and $268 \pm 185 \mu \mathrm{g} / \mathrm{L}$, respectively. The removal efficiency was $53 \pm 28 \%$. These chlorophyll-a results for that wastewater system, with the improvements, were satisfatory, but higher than the legislation's limits for I, II and III water classes before the dilution computation.

For the conventional parameters analysed during the whole period, phosphorus concentrations at the system output were $5 \pm 2 \mathrm{mgP} / \mathrm{L}$ and total nitrogen $22 \pm 10$ $\mathrm{mgN} / \mathrm{L}$ are showed up. It was observed that is necessary the dilution computation for phosphorus for accordance to legislation and for total nitrogen it was verified that the mean value is higher than de limit of $20 \mathrm{mgN} / \mathrm{L}$, according to legislation CONAMA $357 / 2005$.

Key-words: pond stabilization, physico-chemical treatment, cyanobacteria, chlorophyll-a. 


\section{SUMÁRIO}

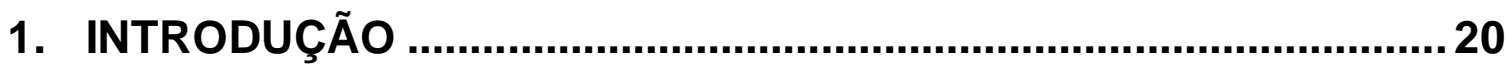

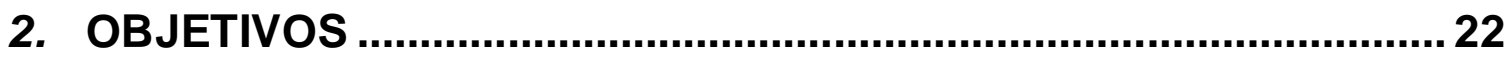

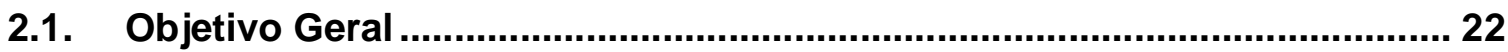

2.2. Objetivos Específicos ............................................................................. 22

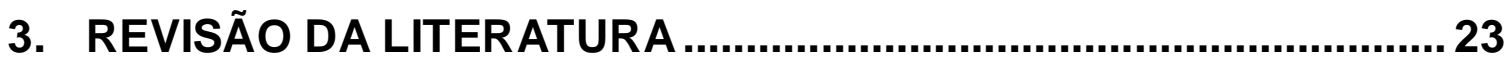

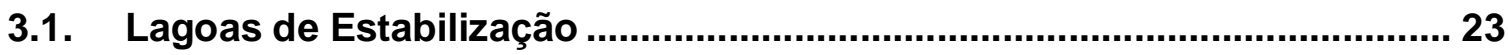

3.1.1. Caracterização dos esgotos sanitários ............................................... 23

3.1.2. Tratamento de Esgoto por Lagoas de Estabilização............................ 27

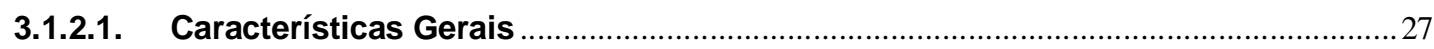

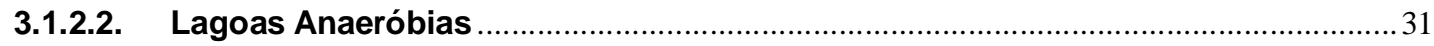

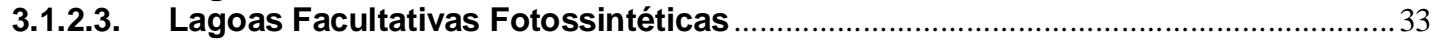

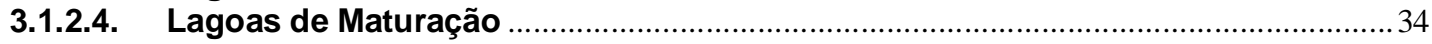

3.1.2.5. Outras características dos Sistemas de Lagoas de Estabilização............................. 35

3.2. Cianobactérias (Cianofíceas) ....................................................................... 39

3.3. Pós Tratamento com Processo Físico-químico.......................................... 41

3.4. Apresentação e discussão sobre a resolução CONAMA № 357/05 …....... 43

4. MATERIAS E MÉTODOS ............................................................... 46

4.1. Descrição do Sistema de Tratamento de Efluentes.................................... 46

4.1.1. Descrição atualizada da ETE da Riviera de São Lourenço ......................... 47

4.1.2. Estação elevatória e emissário de esgoto bruto.......................................... 48

4.1.3. Medição de vazão do esgoto bruto afluente a ETE ..................................... 49

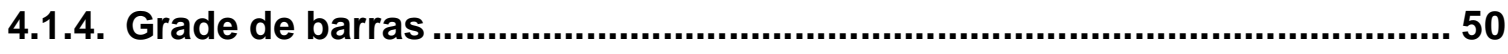


4.1.6. Extravasor de vazões de pico............................................................... 50

4.1.7. Lagoa anaeróbia - LA .................................................................. 51

4.1.8. Coagulação/floculação escalonada ...................................................... 52

4.1.9. Sedimentadores primários -TPQA......................................................... 53

4.1.10. Elevatória de lodo primário .............................................................. 54

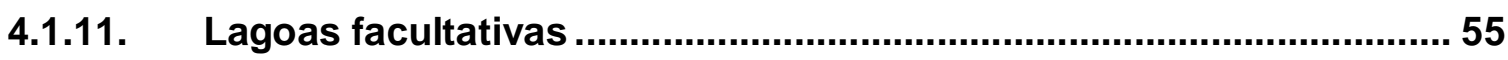

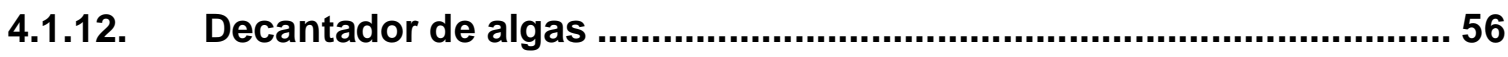

4.1.13. Tanque de contato para desinfecção .............................................. 57

4.1.14. Sistema de preparo e dosagem de cal hidratada ................................ 58

4.1.15. Sistema de preparo e dosagem de polímero ..................................... 59

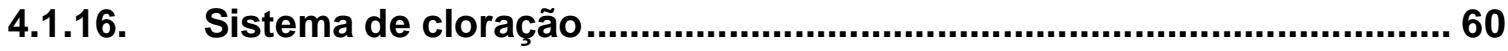

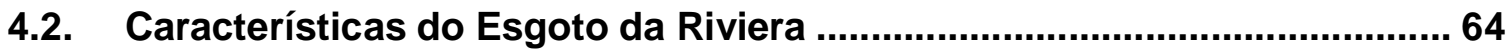

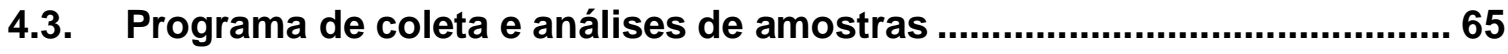

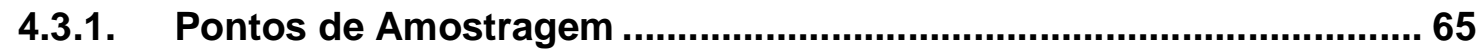

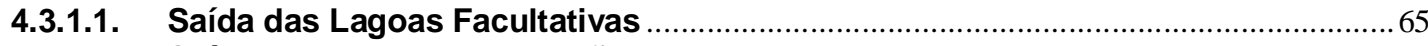

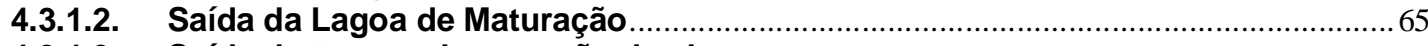

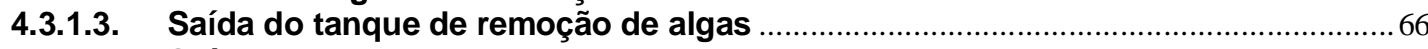

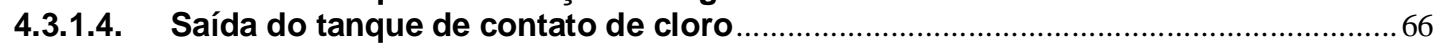

4.4. Parâmetros analisados e freqüência de análises .................................... 67

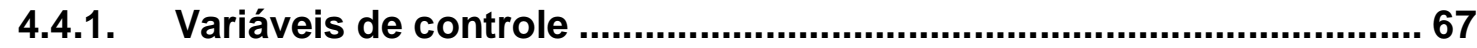

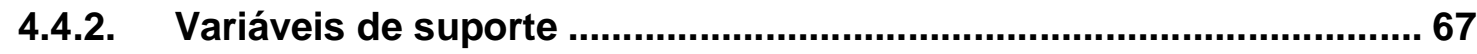

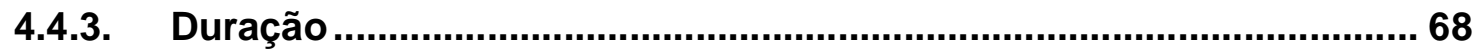

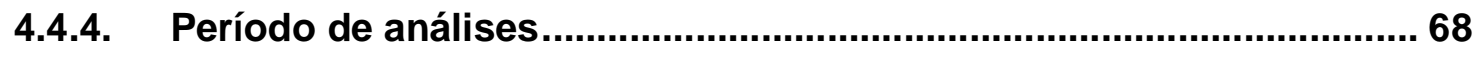

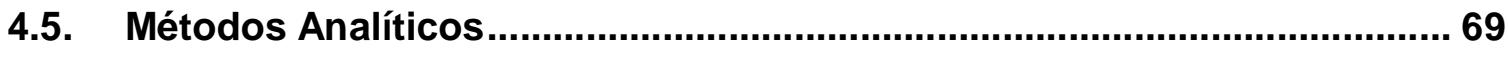

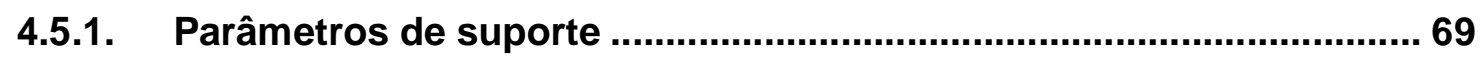

4.5.2. Parâmetros de controle........................................................................ 70 
5. RESULTADOS E DISCUSSÃO

5.1. Resultado de ocorrência de cianobactérias no sistema de tratamento de esgotos..

5.1.1. Avaliação qualitativa

5.2. Resultados dos parâmetros físico-químicos, clorofila-a e cianobactérias 92

5.2.1. Avaliação quantitativa parâmetros físico-químicos 92

5.3. Inter-relações entre resultados 107

6. CONCLUSÕES 114

7. REFERÊNCIAS BIBLIOGRÁFICAS. 118

ANEXO A - RESULTADOS DA ANÁLISE ESTATÍSTICA DAS CONCENTRAÇÕES PARA ENTRADA E SAÍDA DO SISTEMA 122

ANEXO B - RESULTADOS DA ANÁLISE ESTATÍSTICA DAS EFICIÊNCIAS 123

ANEXO C - RESULTADOS DOS BOLETINS DE ANÁLISES DAS CIANOBACTÉRIAS 


\section{ÍNDICE DE FIGURAS}

FIGURA 1: FLUXOGRAMAS DOS SISTEMAS DE LAGOAS DE ESTABILIZAÇÃO...........................

FIGURA 2: TRANSFORMAÇÕES BIOQUÍMICAS EM LAGOAS ANAERÓBIAS...............................32

FIGURA 3: TRANSFORMAÇÕES BIOQUÍMICAS EM LAGOAS FACULTATIVAS............................33

FIGURA 4: TRANSFORMAÇÕES BIOQUÍMICAS EM LAGOAS DE MATURAÇÃO..........................34

FIGURA 5: PRINCIPAIS GÊNEROS E ESPÉCIES DE CIANOBACTÉRIAS NOCIVAS (CHORUS E

BARTRAM, 1999).....

FIGURA 6: FOTO DA LOCALIZAÇÃO DO SISTEMA DE TRATAMENTO DE EFLUENTES DA

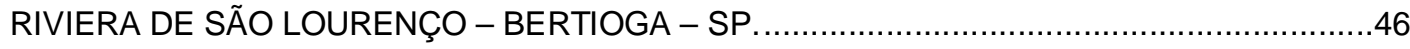

FIGURA 7: FLUXOGRAMA DO SISTEMA OPERACIONAL DE TRATAMENTO DE ESGOTOS DA

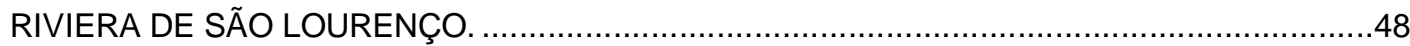

FIGURA 8: ESTAÇÃO ELEVATÓRIA DE ESGOTOS FINAL DA RIVIERA DE SÃO LOURENÇO......49

FIGURA 9: CALHA DE ENTRADA E GRADEAMENTO DA ESTAÇÃO DE TRATAMENTO DE

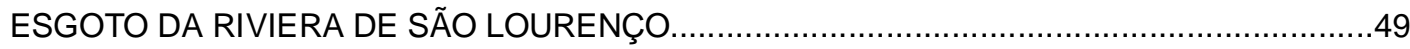

FIGURA 10: CAIXA DE AREIA DA ESTAÇÃO DE TRATAMENTO DE ESGOTO DA RIVIERA DE

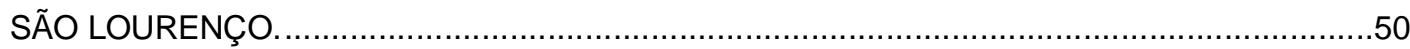

FIGURA 11: EXTRAVASOR DE PICO DA ESTAÇÃO DE TRATAMENTO DE ESGOTO DA RIVIERA

DE SÃO LOURENÇO.

FIGURA 12: LAGOA ANAERÓBIA DA ESTAÇÃO DE TRATAMENTO DE ESGOTO DA RIVIERA DE

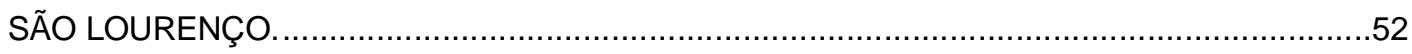

FIGURA 13: FLOCULADORES DO TPQA DA ESTAÇÃO DE TRATAMENTO DE ESGOTO DA

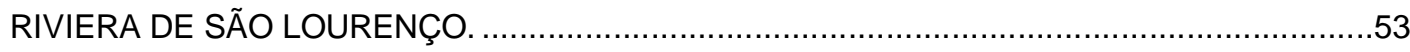

FIGURA 14: SEDIMENTADORES PRIMÁRIOS - TPQA DA ESTAÇÃO DE TRATAMENTO DE

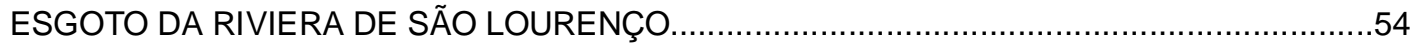

FIGURA 15: BARRILETE DA ELEVATÓRIA DE LODO DA ESTAÇÃO DE TRATAMENTO DE

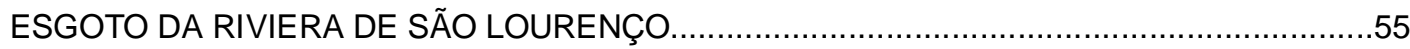

FIGURA 16: LAGOAS FACULTATIVAS E DE MATURAÇÃO DA ESTAÇÃO DE TRATAMENTO DE

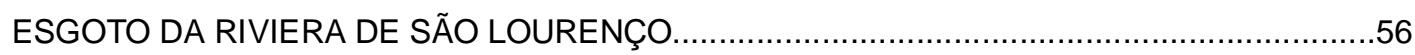

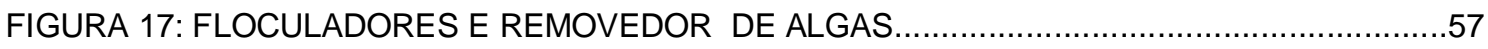

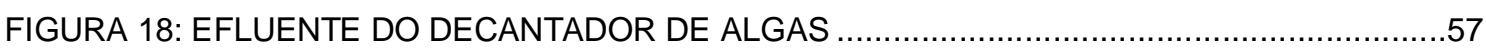

FIGURA 19: TANQUE DE CONTATO DA ESTAÇÃO DE TRATAMENTO DE ESGOTO DA RIVIERA

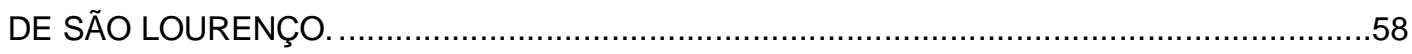

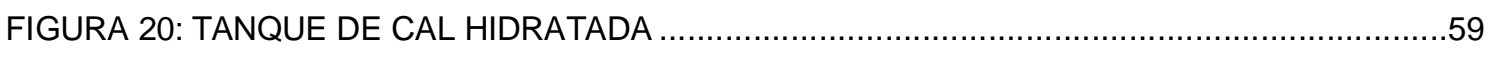

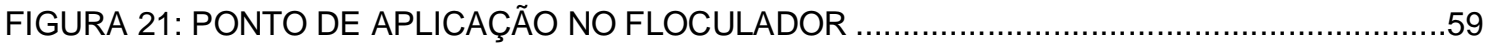

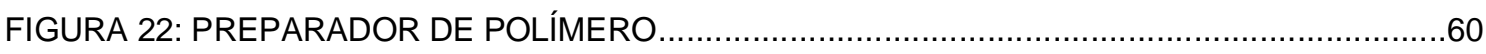

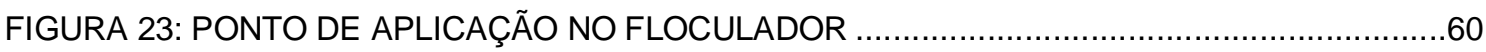

FIGURA 24: SISTEMA DE CLORAÇÃO DA ESTAÇÃO DE TRATAMENTO DE ESGOTO...............60

FIGURA 25: PLANTA BAIXA GERAL DA ENTRADA DO SISTEMA ATÉ O TPQA. .........................62 
FIGURA 26: PLANTA GERAL BAIXA DO FLOCULADOR, SEDIMENTADOR E CAIXA DE CONTATO.

FIGURA 27: VOLUME DE ESGOTO AFLUENTES AO SISTEMA DE TRATAMENTO DE ESGOTO

DA RIVIERA EM 2005

FIGURA 28: VALORES DE DBO AFLUENTES AO SISTEMA DE TRATAMENTO DE ESGOTO DA

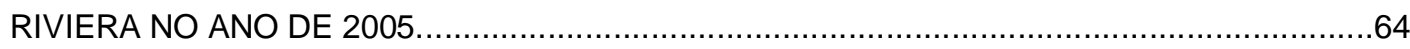

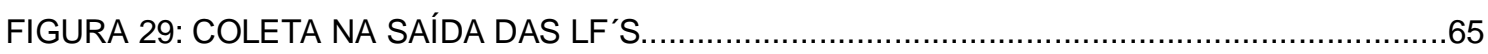

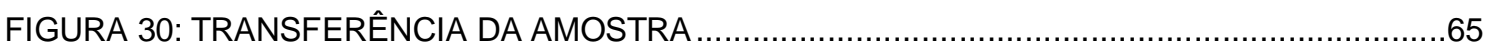

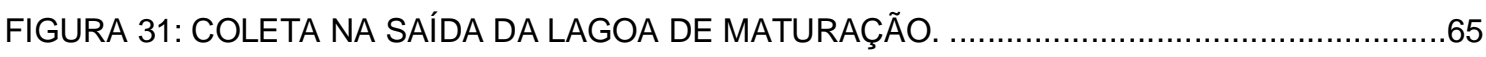

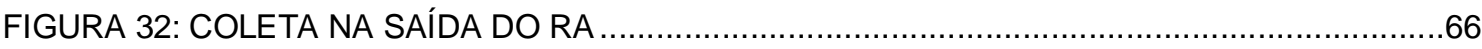

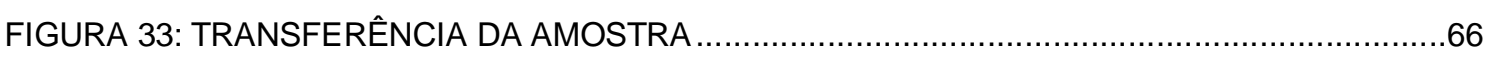

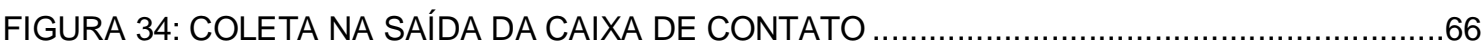

FIGURA 35: TRANSFERÊNCIA DA AMOSTRA PARA O FRASCO ....66

FIGURA 36: SEQÜÊNCIA EXPLICATIVA PARA CONTAGEM DOS CAMPOS. ..............................73

FIGURA 37: TRANSFERÊNCIA DA AMOSTRA PARA O TUBO DE LUGOL ...................................76

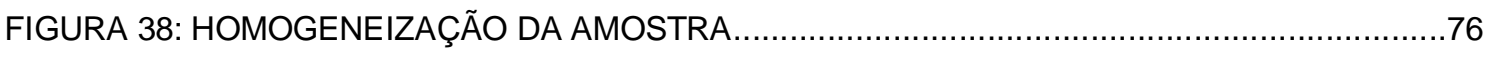

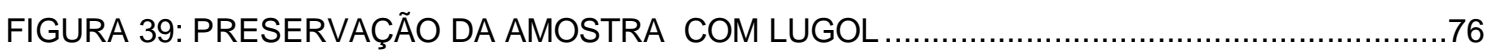

FIGURA 40: ENVOLVIMENTO DO TUBO PARA MANTER A AMOSTRA NO ESCURO ..................76

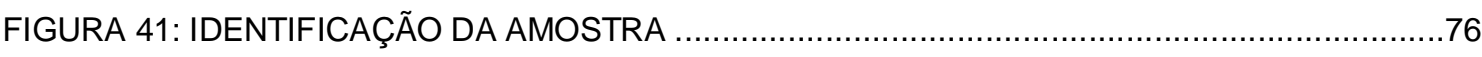

FIGURA 42: PRESERVAÇÃO DA AMOSTRA COM LUGOL EM CUBETAS E FRASCOS DE

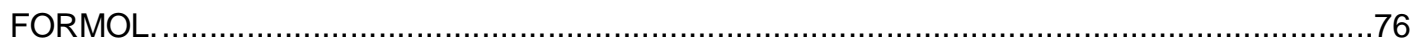

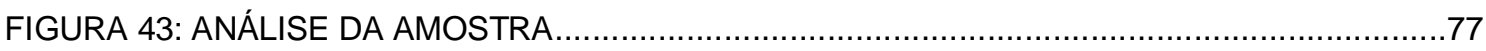

FIGURA 44: MICROSCÓPIO UTILIZADO - NIKON ECLIPSE

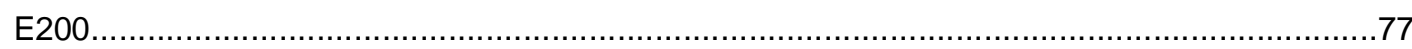

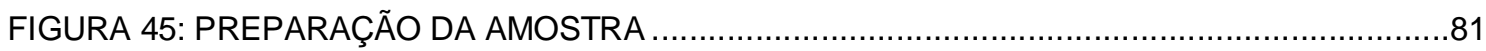

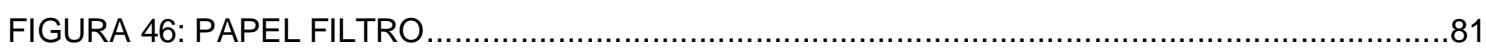

FIGURA 47: FILTRAÇÃO DA AMOSTRA

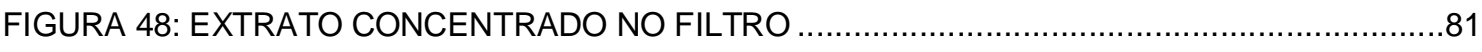

FIGURA 49: ENROLANDO O FILTRO CONCENTRADO DE CLOROFILA .....................................81

FIGURA 50: SOLUÇÃO DE ACETONA 90\% PARA DE CLOROFILA EXTRAÇÃO …......................81

FIGURA 51: ADIÇÃO DE ACETONA PARA EXTRAIR CLOROFILA CONCENTRADA NO FILTRO ..82

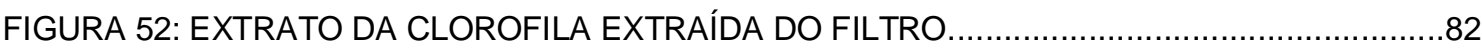

FIGURA 53: TRANSFERÊNCIA DO EXTRATO CONCENTRADO NO FILTRO PARA OUTRO

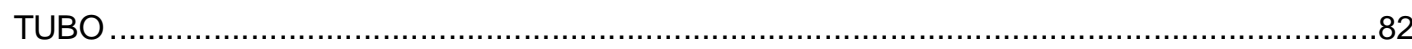

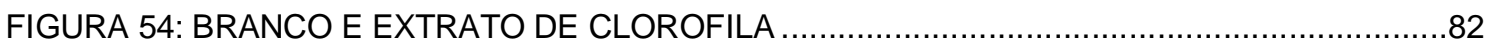

FIGURA 55: DISTRIBUIÇÃO RELATIVA DAS DENSIDADES DE CIANOBACTÉRIAS NA SAÍDA DAS

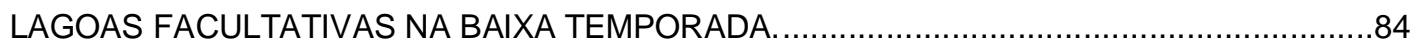

FIGURA 56: DISTRIBUIÇÃO RELATIVA DAS DENSIDADES DE CIANOBACTÉRIAS NA SAÍDA DA

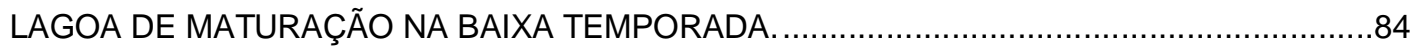


FIGURA 57: DISTRIBUIÇÃO RELATIVA DAS DENSIDADES DE CIANOBACTÉRIAS NA SAÍDA DO DECANTADOR DE ALGAS NA BAIXA TEMPORADA.

FIGURA 58: DISTRIBUIÇÃO RELATIVA DAS DENSIDADES DE CIANOBACTÉRIAS NA SAÍDA DO SISTEMA NA BAIXA TEMPORADA.

FIGURA 59: DISTRIBUIÇÃO RELATIVA DAS DENSIDADES DE CIANOBACTÉRIAS NA SAÍDA DAS LAGOAS FACULTATIVAS NA ALTA TEMPORADA.

FIGURA 60: DISTRIBUIÇÃO RELATIVA DAS DENSIDADES DE CIANOBACTÉRIAS NA SAÍDA DA LAGOA DE MATURAÇÃO NA ALTA TEMPORADA.

FIGURA 61: DISTRIBUIÇÃO RELATIVA DAS DENSIDADES DE CIANOBACTÉRIAS NA SAÍDA DO DECANTADOR DE ALGAS NA ALTA TEMPORADA.

FIGURA 62: DISTRIBUIÇÃO RELATIVA DAS DENSIDADES DE CIANOBACTÉRIAS NA SAÍDA DO SISTEMA NA ALTA TEMPORADA.

FIGURA 63: PRESENÇA RELATIVA DE ESPÉCIES DE CIANOBACTÉRIAS NA BAIXA TEMPORADA

FIGURA 64: PRESENÇA RELATIVA DE ESPÉCIES DE CIANOBACTÉRIAS NA ALTA

TEMPORADA......

FIGURA 65: PRESENÇA RELATIVA DE ESPÉCIES DE CIANOBACTÉRIAS EM TODO O PERÍODO.

FIGURA 66: COMPARAÇÃO ENTRE A SÉRIE DE VALORES TOTAIS DE CIANOBACTÉRIAS NA SAÍDA NO SISTEMA AO LONGO DO PERÍODO ESTUDADO E O LIMITE DA RESOLUÇÃO CONAMA № 357/05 NO CORPO RECEPTOR PARA RIO CLASSE II...................................92

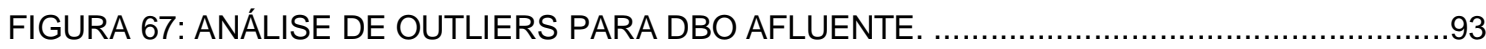

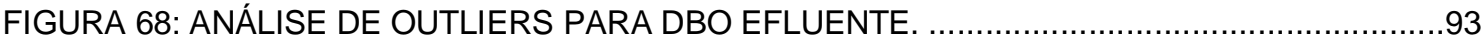

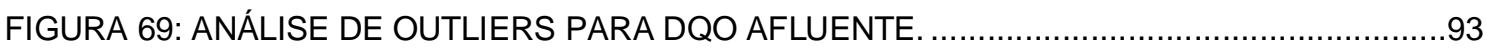

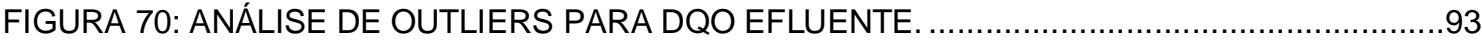

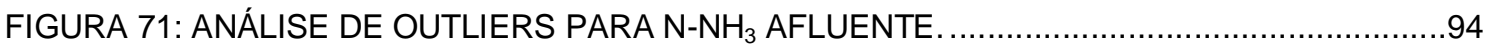

FIGURA 72: ANÁLISE DE OUTLIERS PARA N-NH ${ }_{3}$ EFLUENTE.................................................94

FIGURA 73: ANÁLISE DE OUTLIERS PARA P AFLUENTE

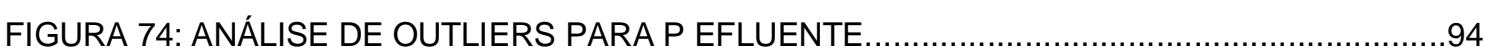

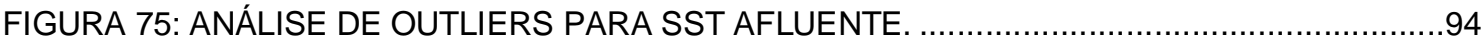

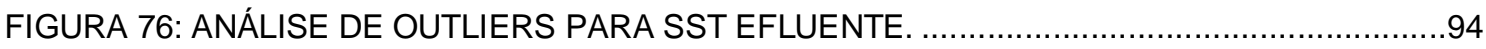

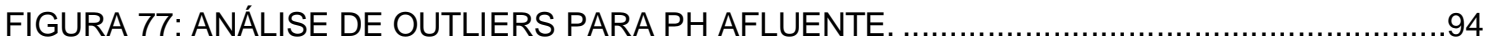

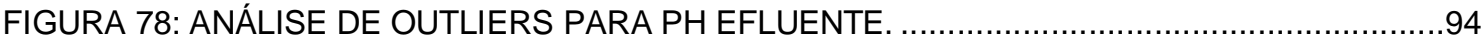

FIGURA 79: ANÁLISE DE OUTLIERS PARA CLOROFILA-A AFLUENTE. ........................................

FIGURA 80: ANÁLISE DE OUTLIERS PARA CLOROFILA-A EFLUENTE...................................95

FIGURA 81: ANÁLISE DE OUTLIERS PARA DENSIDADE DE CIANOBACTÉRIAS AFLUENTE. .....95 FIGURA 82: ANÁLISE DE OUTLIERS PARA DENSIDADE DE CIANOBACTÉRIAS EFLUENTE. .....95 FIGURA 83: ANÁLISE DE OUTLIERS PARA DBO EFLUENTE, SEM OS OUTILERS.....................95 FIGURA 84: ANÁLISE DE OUTLIERS PARA DENSIDADE DE CIANOBACTÉRIAS AFLUENTE, SEM 
FIGURA 85: ANÁLISE DE OUTLIERS PARA DENSIDADE DE CIANOBACTÉRIAS EFLUENTE, SEM

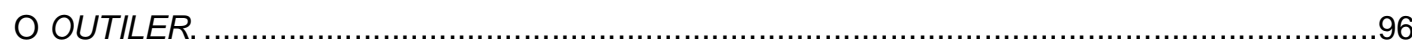

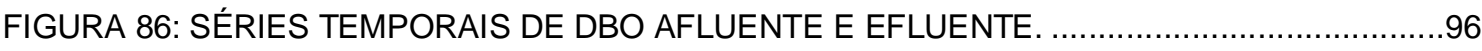

FIGURA 87: SÉRIES TEMPORAIS DA EFICIÊNCIA DE REMOÇÃO DE DBO.............................96

FIGURA 88: GRÁFICO BOX AND WISKERS DA DBO AFLUENTE E EFLUENTE. .........................97

FIGURA 89: GRÁFICO BOX AND WISKERS DA EFICIÊNCIA DE REMOÇÃO DE DBO..................97

FIGURA 90: DESVIO PADRÃO DAS SÉRIES TEMPORAIS DE DBO AFLUENTE E EFLUENTE. ....97

FIGURA 91: DESVIO PADRÃO DA EFICIÊNCIA DE REMOÇÃO DE DBO ..................................97

FIGURA 92: SÉRIES TEMPORAIS DE DQO AFLUENTE E EFLUENTE....................................98

FIGURA 93: SÉRIES TEMPORAIS DA EFICIÊNCIA DE REMOÇÃO DE DQO ….........................98

FIGURA 94: GRÁFICO BOX AND WISKERS DA DQO AFLUENTE E EFLUENTE.........................98

FIGURA 95: GRÁFICO BOX AND WISKERS DA EFICIÊNCIA DE REMOÇÃO DE DQO. ...............98

FIGURA 96: DESVIO PADRÃO DAS SÉRIES TEMPORAIS DE DQO AFLUENTE E EFLUENTE. ....98

FIGURA 97: DESVIO PADRÃO DA EFICIÊNCIA DE REMOÇÃO DE DQO...................................98

FIGURA 98: SÉRIES TEMPORAIS DE N-NH ${ }_{3}$ AFLUENTE E EFLUENTE..................................99

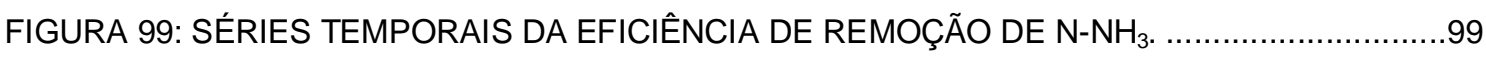

FIGURA 100: GRÁFICO BOX AND WISKERS DE N-NH ${ }_{3}$ AFLUENTE E EFLUENTE......................99

FIGURA 101: GRÁFICO BOX AND WISKERS DA EFICIÊNCIA DE REMOÇÃO DE N-NH $\mathrm{N}_{3} \ldots \ldots \ldots \ldots . . . . .99$

FIGURA 102: DESVIO PADRÃO DAS SÉRIES TEMPORAIS DE N-NH ${ }_{3}$ AFLUENTE E EFLUENTE. 99

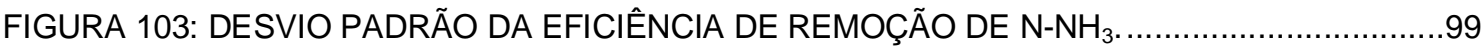

FIGURA 104: SÉRIES TEMPORAIS DE P AFLUENTE E EFLUENTE........................................ 100

FIGURA 105: SÉRIES TEMPORAIS DA EFICIÊNCIA DE REMOÇÃO DE P................................100

FIGURA 106: GRÁFICO BOX AND WISKERS DE P AFLUENTE E EFLUENTE. ..........................100

FIGURA 107: GRÁFICO BOX AND WISKERS DA EFICIÊNCIA DE REMOÇÃO DE P....................100

FIGURA 108: DESVIO PADRÃO DAS SÉRIES TEMPORAIS DE P AFLUENTE E EFLUENTE........101

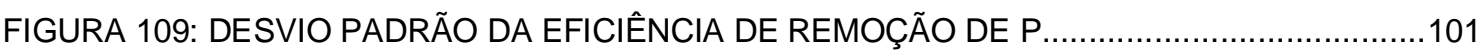

FIGURA 110: SÉRIES TEMPORAIS DE SST AFLUENTE E EFLUENTE. ....................................102

FIGURA 111: SÉRIES TEMPORAIS DA EFICIÊNCIA DE REMOÇÃO DE SST..............................102

FIGURA 112: GRÁFICO BOX AND WISKERS DE SST AFLUENTE E EFLUENTE. ........................102

FIGURA 113: GRÁFICO BOX AND WISKERS DA EFICIÊNCIA DE REMOÇÃO DE SST. ..............102

FIGURA 114: DESVIO PADRÃO DAS SÉRIES TEMPORAIS DE SST AFLUENTE E EFLUENTE. .102

FIGURA 115: DESVIO PADRÃO DA EFICIÊNCIA DE REMOÇÃO DE SST. .................................102

FIGURA 116: SÉRIES TEMPORAIS DE PH AFLUENTE E EFLUENTE. .....................................103

FIGURA 117: GRÁFICO BOX AND WISKERS DO PH AFLUENTE E EFLUENTE. .........................103

FIGURA 118: DESVIO PADRÃO DAS SÉRIES TEMPORAIS DE PH AFLUENTE E EFLUENTE. ...103

FIGURA 119: SÉRIES TEMPORAIS DE CLOROFILA-A DO DECANTADOR DE ALGAS(AFLUENTE)

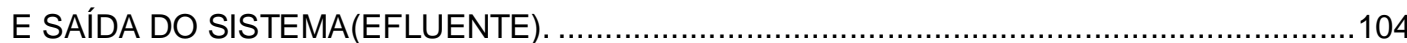

FIGURA 120: SÉRIES TEMPORAIS DA EFICIÊNCIA DE REMOÇÃO DE CLOROFILA-A DO DECANTADOR DE ALGAS(AFLUENTE) E SAÍDA DO SISTEMA(EFLUENTE). 
FIGURA 121: GRÁFICO BOX AND WISKERS DA CLOROFILA-A DO DECANTADOR DE ALGAS(AFLUENTE) E SAÍDA DO SISTEMA(EFLUENTE). 104

FIGURA 122: GRÁFICO BOX AND WISKERS DA EFICIÊNCIA DE REMOÇÃO DE CLOROFILA-A

DO DECANTADOR DE ALGAS(AFLUENTE) E SAÍDA DO SISTEMA(EFLUENTE). 104

FIGURA 123: DESVIO PADRÃO DAS SÉRIES TEMPORAIS DE CLOROFILA-A DO DECANTADOR

DE ALGAS(AFLUENTE) E SAÍDA DO SISTEMA(EFLUENTE). 104

FIGURA 124: DESVIO PADRÃO DA EFICIÊNCIA DE REMOÇÃO DE CLOROFILA-A DO DECANTADOR DE ALGAS(AFLUENTE) E SAÍDA DO SISTEMA(EFLUENTE). 104

FIGURA 125: SÉRIES TEMPORAIS DE DENSIDADE DE CIANOBACTÉRIAS AFLUENTE E EFLUENTE. 106

FIGURA 126: SÉRIES TEMPORAIS DA EFICIÊNCIA DE REMOÇÃO DE CIANOBACTÉRIAS.......106 FIGURA 127: GRÁFICO BOX AND WISKERS DA DENSIDADE DE CIANOBACTÉRIAS AFLUENTE E EFLUENTE. 106

FIGURA 128: GRÁFICO BOX AND WISKERS DA EFICIÊNCIA DE REMOÇÃO DE CIANOBACTÉRIAS. 106

FIGURA 129: DESVIO PADRÃO DAS SÉRIES TEMPORAIS DE CIANOBACTÉRIAS AFLUENTE E EFLUENTE. 107

FIGURA 130: DESVIO PADRÃO DA EFICIÊNCIA DE REMOÇÃO DE CIANOBACTÉRIAS. 107 FIGURA 131: SÉRIES TEMPORAIS DE DBO, DENSIDADE DE CIANOBACTÉRIAS E CLOROFILA-A NA SAÍDA DO SISTEMA. 109 FIGURA 132: SÉRIES TEMPORAIS DE DQO, DENSIDADE DE CIANOBACTÉRIAS E CLOROFILAA NA SAÍDA DO SISTEMA 110 FIGURA 133: SÉRIES TEMPORAIS DE N-NH ${ }_{3}$, DENSIDADE DE CIANOBACTÉRIAS E CLOROFILAA NA SAÍDA DO SISTEMA.

FIGURA 134: SÉRIES TEMPORAIS DE P, DENSIDADE DE CIANOBACTÉRIAS E CLOROFILA-A NA SAÍDA DO SISTEMA.

FIGURA 135: SÉRIES TEMPORAIS DE SST, DENSIDADE DE CIANOBACTÉRIAS E CLOROFILA-A NA SAÍDA DO SISTEMA. 


\section{ÍNDICE DE TABELAS}

TABELA 1: CARACTERÍSTICAS FÍSICO-QUÍMICAS DOS ESGOTOS. FONTE: METCALF \& EDDY (1991).

TABELA 2: COMPOSIÇÃO DOS ESGOTOS SANITÁRIOS. FONTE: ADAPTADA DE VON SPERLING (2001). 25

TABELA 3: CONCENTRAÇÕES DE SÓLIDOS EM ESGOTOS. FONTE: METCALF \& EDDY (1991). .26

TABELA 4: PRINCIPAIS PARÂMETROS DE PROJETO DE LAGOAS DE ESTABILIZAÇÃO.............35 TABELA 5: FAIXAS DE EFICIÊNCIAS DE REMOÇÃO DE CONSTITUINTES FÍSICO-QUÍMICOS EM LAGOAS DE ESTABILIZAÇÃO. 36

TABELA 6: FAIXAS DE EFICIÊNCIAS DE REMOÇÃO DE ORGANISMOS PATOGÊNICOS E INDICADORES EM LAGOAS DE ESTABILIZAÇÃO. 37

TABELA 7: TAXAS DE ACÚMULO E CARACTERÍSTICAS DOS LODOS DE LAGOAS DE ESTABILIZAÇÃO.

TABELA 8: CARACTERÍSTICAS DAS LAGOAS DE ESTABILIZAÇÃO DA ETE DA RIVIERA DE SÃO LOURENÇO. .61

TABELA 9: FREQÜÊNCIA DE ANÁLISE DAS VARIÁVEIS DE CONTROLE .................................67

TABELA 10: FREQÜÊNCIA DE ANÁLISE DAS VARIÁVEIS DE SUPORTE ..................................68

TABELA 11: MÉTODOS DE DETERMINAÇÃO DOS PARÂMETROS DE SUPORTE ......................69 TABELA 12: CÁLCULO DA ÁREA DO CAMPO DA LÂMINA PARA ANÁLISE DE CIANOBACTÉRIAS.

TABELA 13: CONVERSÃO PARA FATOR DE CONTAGEM DE CIANOBACTÉRIAS. .....................75

TABELA 14: DISTRIBUIÇÃO RELATIVA MÉDIA DAS CONCENTRAÇÕES DE CÉLULAS DE

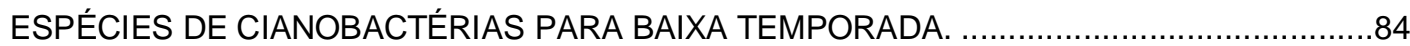

TABELA 15: DISTRIBUIÇÃO RELATIVA MÉDIA DAS CONCENTRAÇÕES DE CÉLULAS DE ESPÉCIES DE CIANOBACTÉRIAS PARA ALTA TEMPORADA.

TABELA 16: TOTAL DE AMOSTRAS EM CADA PONTO COLETADO E A PRESENÇA DE CIANOBACTÉRIAS POR ESPÉCIE NO SISTEMA. .89

TABELA 17: RESULTADOS DE CONCENTRAÇÃO DE CLOROFILA-A PARA OS PONTOS A MONTANTE E JUSANTE DO LANÇAMENTO DO EFLUENTE TRATADO NO CORPO RECEPTOR AO LONGO DO PERÍODO ESTUDADO 106

TABELA 18: MÉDIA, MÁXIMA E MÍNIMA DAS RELAÇÕES ENTRE DENSIDADE DE CIANOBACTÉRIAS EFLUENTE E MÉDIA DAS CONCENTRAÇÕES DOS PARÂMETROS DE SUPORTE E CLOROFILA-A... 108

TABELA 19: MÉDIA, MÁXIMA E MÍNIMA DAS RELAÇÕES ENTRE AS CONCENTRAÇÕES DE CLOROFILA-A EFLUENTE E MÉDIA DAS CONCENTRAÇÕES DOS PARÂMETROS DE SUPORTE. 


\section{INTRODUÇÃO}

O processo de Lagoas de Estabilização constitui uma técnica de tratamento de esgoto atraente para pequenas e médias comunidades, principalmente devido ao baixo custo e simplicidade operacional, boa eficiência de remoção de matéria orgânica e patógenos. Porém, por envolverem processos biológicos e fazerem uso de organismos fotossintetizantes (como as algas) para a oxigenação, estes sistemas também geram condições para a proliferação de cianobactérias e, conseqüentemente, para a produção de toxinas. Com a recente reformulação da Resolução Federal CONAMA 20/1986 para a CONAMA 357/2005, sendo que vários parâmetros foram revisados e inseridos, como por exemplo, densidade de cianobactérias, concentração de clorofila-a e a exigência de realização de testes de toxicidade. Gerou-se, desta forma, uma necessidade de ação, que nos leve a avaliar as potenciais dificuldades que estes sistemas de lagoas de estabilização podem apresentar em relação ao atendimento aos padrões de qualidade estabelecidos em normas.

A Riviera de São Lourenço localiza-se no município de Bertioga, litoral norte do estado de São Paulo. O sistema de tratamento de efluentes está situado às margens da rodovia Rio-Santos, a aproximadamente $2,5 \mathrm{~km}$ do empreendimento.

Inicialmente foi concebido como um tratamento biológico (sistema australiano); uma lagoa anaeróbia seguida de duas lagoas facultativas, já reservando espaço físico para construções de mais lagoas. Em 1998 foi construída mais uma lagoa facultativa ao lado das outras duas existentes e praticamente com a mesma capacidade volumétrica, com todas trabalhando em paralelo.

Com o contínuo crescimento do empreendimento Riviera, se fez necessário novamente à ampliação do sistema em 1999, pois, a capacidade de tratamento estava começando a saturar para a ocupação máxima e havia o problema da sazonalidade, ou seja, as lagoas recebiam uma carga muito grande em função do aumento da população, motivado por um feriado, férias de fim de ano ou finais de semana de muito sol. 
Utilizou-se, então, para uma segunda ampliação, o sistema de tratamento físicoquímico também conhecido como CEPT (Chemically Enhanced Primary Treatment) ou TPQA (Tratamento Primário Quimicamente Assistido), sendo o primeiro sistema implantado no Brasil. Tal sistema ocupa pouco espaço físico e pode-se utilizar a aplicação de produtos químicos somente na alta temporada. O TPQA é um tratamento que utiliza o princípio da coagulação - floculação, muito utilizado para tratamento de água, através da aplicação de um sal férrico que no caso da Rivera de São Lourenço foi o cloreto férrico (40 mg/L) e um polímero aniônico $(0,5 \mathrm{mg} / \mathrm{L})$, com o intuito de promover a remoção da DBO, SST, e Nutrientes - N e P. Sendo assim, ele seria posto em operação sempre que a ocupação superasse a capacidade de tratamento das lagoas.

Atualmente, o sistema de operação sofreu novas alterações, visando aumentar o desempenho operacional da estação de tratamento de esgotos sanitários da Riviera de São Lourenço durante o ano de 2005, para atendimento ao crescimento populacional e com o intuito de se adequar nova legislação CONAMA 357/2005, foram concebidas, projetadas e implantadas novas unidades, resultando para a ETE - RSL (Estação de tratamento de esgoto da Riviera de São Lourenço) uma nova conFiguração, com mudança de produto químico e instalação de um tanque Decantador de algas. 


\section{OBJETIVOS}

\subsection{Objetivo Geral}

O objetivo geral do presente estudo é avaliar quantitativamente e qualitativamente a presença de cianobactérias e quantitativamente a concentração de clorofila-a nos efluentes de um sistema de lagoas de estabilização, possuindo unidades de pré e pós-tratamento por processo físico-químico, utilizado para o tratamento de esgoto sanitário.

\subsection{Objetivos Específicos}

- Avaliar as condições operacionais do sistema de tratamento utilizado, recorrendose aos parâmetros de controle convencionais e suas respectivas eficiências de remoção.

- Avaliar a geração de cianobactérias e clorofila-a em lagoas facultativas e de maturação, de forma associada às concentrações de Demanda Bioquímica de Oxigênio (DBO), Demanda Química de Oxigênio (DQO), Sólidos Suspensos Totais

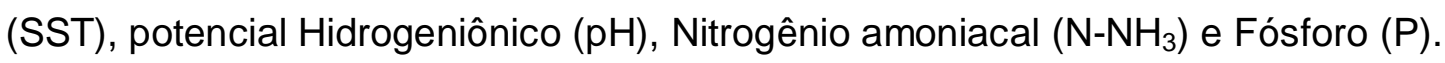

- Avaliar a redução na densidade de cianobactérias e concentração de clorofila-a decorrente da aplicação de tratamento físico-químico à base de floculação e cloração final. 


\section{REVISÃO DA LITERATURA}

\subsection{Lagoas de Estabilização}

Em vista do planejamento experimental e dos resultados que se pretende obter e discutir, um aspecto inicial que se pretende abordar na revisão de literatura refere-se ao funcionamento das lagoas de estabilização. O objetivo principal é a avaliação do comportamento deste processo na transformação das características físicas, químicas e biológicas dos esgotos. Nesta etapa, serão apresentados também dados acerca das características dos esgotos "in natura", para servirem de referência para os resultados práticos levantados nas condições peculiares do sistema da Riviera de São Lourenço - Bertioga - SP.

Em seguida, é realizada uma revisão bibliográfica do tema em questão, cianobactérias (cianofíceas) e algas (clorofíceas).

O passo seguinte será a discussão do pós-tratamento de efluentes de lagoas de estabilização por processo físico-químico, com aplicação de polímero, cal hidratada e cloro gás e separação de sólidos (algas e cianobactérias) por sedimentação.

\subsubsection{Caracterização dos esgotos sanitários}

Os esgotos sanitários são constituídos dos esgotos domésticos propriamente ditos, das águas de infiltração na rede coletora provenientes do lençol freático e de contribuições específicas, principalmente indústrias que descarregam seus efluentes líquidos no sistema público. Suas características variam no espaço, em função de variáveis como o tipo de ocupação da bacia de esgotamento, que pode ser estritamente residencial ou associada a áreas comerciais e industriais, do clima e até de hábitos culturais e condição social da comunidade. Variam também ao longo do tempo, nas horas do dia, nos dias da semana e sazonalmente, o que torna complexa 
sua caracterização. Não são disponíveis na literatura brasileira, trabalhos que identifiquem com segurança estatística as características de nossos esgotos sanitários. Metcalf \& Eddy (1991) classificam os esgotos em forte, médio e fraco, conforme as características apresentadas na Tabela 1.

Tabela 1: Características Físico-Químicas dos Esgotos. Fonte: Metcalf \& Eddy (1991).

\begin{tabular}{lccc}
\hline Característica & Forte & Médio & Fraco \\
\hline $\mathrm{DBO}_{5,20}(\mathrm{mg} / \mathrm{L})$ & 400 & 220 & 110 \\
$\mathrm{DQO}(\mathrm{mg} / \mathrm{L})$ & 1.000 & 500 & 250 \\
Carbono Org. Total (mg/L) & 290 & 160 & 80 \\
Nitrogênio total - NTK (mg/L) & 85 & 40 & 20 \\
Nitrogênio Orgânico (mg/L) & 35 & 15 & 08 \\
Nitrogênio Amoniacal (mg/L) & 50 & 25 & 12 \\
Fósforo Total (mg/L) & 15 & 08 & 04 \\
Fósforo Orgânico (mg/L) & 05 & 03 & 01 \\
Fósforo Inorgânico (mg/L) & 10 & 05 & 03 \\
Cloreto (mg/L) & 100 & 50 & 30 \\
Sulfato (mg/L) & 50 & 30 & 20 \\
Óleos e Graxas (mg/L) & 150 & 100 & 50 \\
\hline
\end{tabular}

Von Sperling et al. (2003) realizaram uma compilação de dados de características de esgotos Sanitários de diversas regiões do Brasil, cujo resultado é apresentado na Tabela 2. 
Tabela 2: Composição dos Esgotos Sanitários. Fonte: Adaptada de Von Sperling (2001).

\begin{tabular}{lcc}
\hline Parâmetro & Unidade & Faixa de Resultados \\
\hline DQO & $\mathrm{mg} / \mathrm{L}$ & $500-800$ \\
$\mathrm{DBO}_{5}$ & $\mathrm{mg} / \mathrm{L}$ & $200-350$ \\
$\mathrm{SST}$ & $\mathrm{mg} / \mathrm{L}$ & $300-400$ \\
$\mathrm{NTK}$ & $\mathrm{mgN} / \mathrm{L}$ & $35-50$ \\
P-Total & $\mathrm{mgP} / \mathrm{L}$ & $6-10$ \\
Sólidos Sedimentáveis & $\mathrm{mL} / \mathrm{L}$ & $10-20$ \\
pH & - & $7,0-8,0$ \\
Coliformes fecais & $\mathrm{CF} / 100 \mathrm{~mL}$ & $10^{7}-10^{9}$ \\
Ovos de Helmintos & $\mathrm{N}^{\circ} / \mathrm{L}$ & $10-200$ \\
\hline
\end{tabular}

No Brasil, mesmo que não se tenha informação segura com base local, costuma-se adotar a contribuição "per capita" de 54g/habitante.dia para a DBO de cinco dias.

Em termos de vazão, pode-se afirmar que os esgotos estão sujeitos às mesmas variações relativas ao consumo de água, variando de região para região, dependendo principalmente do poder aquisitivo da população. Apenas a título de referência, pode-se considerar a contribuição típica de $160 \mathrm{~L} /$ habitante.dia, referente ao consumo "per capita" de água de $200 \mathrm{~L} /$ habitante.dia e um coeficiente de retorno água/esgoto igual a 0,8. Para a determinação das vazões máximas de esgotos, costuma-se introduzir os coeficientes $\mathrm{k}_{1}=1,2$ (relativo ao dia de maior produção) e $\mathrm{k}_{2}=1,5$ (relativo à hora de maior produção de esgotos). Conseqüentemente, $\mathrm{a}$ vazão de esgotos do dia e hora de maior produção é 1,8 vezes, o valor médio diário. (Sobrinho e Tomoyuki, 1999). 
Os esgotos sanitários possuem elevadas concentrações de nitrogênio e fósforo. Isto faz com que, ao serem submetidos a tratamento biológico, haverá incorporação desses macronutrientes nas células que tomam parte do sistema, mas o excedente dos mesmos ainda deverá ser grande. Esta é uma importante preocupação em termos de tratamento de esgotos, exigindo tratamento avançado quando se tem lançamento em situações mais restritivas, sobretudo em represas utilizadas para o abastecimento público de água potável, onde o problema da eutrofização (aporte de teores excessivos de nitrogênio e fósforo no corpo receptor) poderá ter conseqüências drásticas.

$\mathrm{Na}$ Tabela 3 são apresentadas concentrações típicas das diversas frações de sólidos em esgotos:

Tabela 3: Concentrações de Sólidos em Esgotos. Fonte: Metcalf \& Eddy (1991).

\begin{tabular}{lccc}
\hline Característica & Forte & Médio & Fraco \\
\hline Sólidos Totais (mg/L) & 1.200 & 720 & 350 \\
Sólidos Dissolvidos (mg/L) & 850 & 500 & 250 \\
Sólidos Dissolvidos Fixos (mg/L) & 850 & 500 & 250 \\
Sólidos Dissolvidos Voláteis (mg/L) & 525 & 300 & 145 \\
Sólidos em Suspensão Totais (mg/L) & 350 & 220 & 100 \\
Sólidos em Suspensão Fixos (mg/L) & 75 & 55 & 20 \\
Sólidos em Suspensão Voláteis (mg/L) & 275 & 165 & 80 \\
Sólidos Sedimentáveis (mL/L) & 20 & 10 & 05 \\
\hline
\end{tabular}

Com relação a todas as características físico-químicas e/ou biológicas dos esgotos, pode-se dizer que ocorrem variações significativas, que fazem com que as diferenças apresentadas entre os resultados das diversas referências consultadas sejam aceitáveis. 


\subsubsection{Tratamento de Esgoto por Lagoas de Estabilização}

\subsubsection{Características Gerais}

As lagoas de estabilização são sistemas de tratamento biológicos em que a estabilização/degradação da matéria orgânica é realizada pela oxidação bacteriológica (oxidação aeróbia ou fermentação anaeróbia) e/ou redução fotossintética das algas (Jordão e Pessoa, et al.;2005).

As lagoas apresentam excelente eficiência de tratamento. A matéria orgânica dissolvida no efluente das lagoas é bastante estável, e a DBO geralmente encontrase numa faixa de 30 a 50 mg/L, nas lagoas facultativas (havendo uma separação de algas, esta concentração pode reduzir-se para 20 a 30mg/L).

Em termos de eficiência de remoção de DBO a faixa típica situa-se entre $75 \%$ e $85 \%$ (Jordão e Pessoa, 2005).

O principal objetivo das lagoas de estabilização é a remoção de matéria carbonácea, com exceção das Lagoas de Maturação.

As lagoas de estabilização são tanques construídos em terra de forma a receber os esgotos continuamente, garantindo elevados tempos de retenção destes e propiciando mecanismos naturais para a degradação de matéria orgânica e para a redução da concentração de microrganismos. Não há introdução artificial de oxigênio ou aeração eletro-mecânica.

As lagoas de estabilização podem ser classificadas em anaeróbias, facultativas e de maturação. As lagoas anaeróbias são escavações mais profundas, com altura útil variando na faixa de 3 a 5 metros, retendo os esgotos durante 4 a 6 dias. Nestas condições, garante-se a anaerobiose, uma vez que a penetração de luz e a sobrevivência de algas só são possíveis e de forma bastante limitada apenas em estreita camada superficial. Por outro lado, a taxa de aplicação de matéria orgânica 
é forçada, provocando o rápido esgotamento do oxigênio que por ventura esteja presente nos esgotos afluentes. Para as nossas condições de temperatura e para as demais anteriormente citadas, obtêm-se eficiências na remoção da $\mathrm{DBO}_{5}$ dos esgotos da ordem de 40 a $60 \%$.

As lagoas facultativas são escavações mais rasas, com profundidades típicas na faixa de 1,5 a 2,0 m e áreas de espelho de água relativamente maiores do que as das anaeróbias. Os sólidos sedimentáveis presentes nos esgotos depositam-se no fundo das lagoas facultativas, entrando em decomposição anaeróbia. A matéria orgânica solúvel mantém-se na massa líquida, sofrendo decomposição aeróbia pela ação de microrganismos heterotróficos, que aproveitam o oxigênio liberado pela fotossíntese de algas bem como decorrente da ventilação superficial. O gás carbônico resultante da decomposição da matéria orgânica é utilizado como matéria prima para o processo fotossintético, fechando o ciclo da simbiose entre algas e bactérias aeróbias que caracteriza o processo. Estas lagoas, em condições normais de operação, são capazes de propiciar eficiências na remoção de $\mathrm{DBO}_{5}$ superiores a $80 \%$.

Como vantagens do emprego de sistemas de lagoas de estabilização podem ser listados: O baixo custo de implantação do sistema, exceto se a área for muito valorizada ou se houver necessidade de substituição de solo; a operação é bastante simples, sendo bastante adequados para pequenas populações onde as companhias possuem menores recursos; o projeto é bastante simples e o terreno é reaproveitável. Como principais desvantagens podem ser listadas a exigência de áreas relativamente grandes, a presença de elevadas concentrações de algas no efluente final e a emanação de maus odores das lagoas anaeróbias.

Dois principais arranjos podem ser utilizados. O denominado "sistema australiano" que é constituído do tratamento preliminar, seguido de lagoas anaeróbias, facultativas e de maturação. No sistema com lagoa facultativa primária, não se inclui lagoas anaeróbias. Com isso o sistema ocupa maior área, mas evita-se as possibilidades de exalação de maus odores das lagoas anaeróbias. 
Outro fator importante é a presença de algas nas lagoas de estabilização, numa lagoa de estabilização facultativa, as algas desempenham um papel fundamental. A sua concentração é mais elevada do que a de bactérias, fazendo com que o líquido na superfície da lagoa seja predominantemente verde. Em termos de sólidos em suspensão secos, a concentração é usualmente inferior a $200 \mathrm{mg} / \mathrm{L}$, embora em termos de numero as algas possam atingir contagem de $10^{4}$ a $10^{6}$ organismos por mL (Arceivala, 1981, apud Jordão e Pessoa, 2005).

Os principais tipos de algas encontrados nas lagoas de estabilização são as algas verdes (clorofíceas) e algas azuis (cianofícias ou cianobactérias) (Silva Jr. Sasson, 1993,apud Jordão e Pessoa, 2005):

As clorofíceas conferem a lagoa à cor esverdeada predominante. Os principais gêneros são as Chlamydomonas, Euglenas e Chlorella. Os dois primeiros gêneros são normalmente os primeiros a aparecer na lagoa, tendendo a ser dominantes nos períodos frios, e possuindo flagelos, o que lhes conferem a capacidade de locomoção. O gênero Euglemna tem grande capacidade de adaptação a diferentes condições climáticas.

As cianobactérias, na realidade, são muitas vezes referidas como se aproximando mais das bactérias do que das algas propriamente ditas. As cianobactérias nunca apresentam organelas de locomoção como cílios, flagelos ou pseudópodes, mas podem se deslocar por deslizamento. Os requisitos de nutrientes são bastante reduzidos:

As cianobactérias podem proliferar em qualquer ambiente onde haja apenas $\mathrm{CO}_{2} \mathrm{e}$ $\mathrm{N}_{2}$, água, alguns minerais e luz. Tais algas são típicas de situações com baixos valores de $\mathrm{pH}$ e baixa concentração de nutrientes. Nestas condições, as algas verdes não encontram ambiente favorável, ou servem de alimento a outros organismos, como protozoários, conduzindo ao desenvolvimento das cianobactérias. Entre os principais gêneros podem se citar Oscillatoria, Phormidium, Anacystis, Anabaena, Microcistis e etc. 
As algas fazem a fotossíntese durante as horas do dia, sujeitas à radiação luminosa. Neste período elas produzem a matéria orgânica necessária para a sua sobrevivência, convertendo a energia luminosa em energia química condensada na forma de alimento. Durante as 24 horas do dia elas respiram, oxidando a matéria orgânica produzida, e liberando a energia para crescimento, reprodução, locomoção e outros. O balanço entre produção (fotossíntese) e consumo (respiração) de oxigênio favorece amplamente o primeiro. De fato, as algas produzem cerca de 15 vezes mais oxigênio do que consomem (Abdel - Razik, 1991), conduzindo a um saldo positivo no sistema.

Devido à necessidade de energia luminosa, a maior quantidade de algas situa-se próximo à superfície da lagoa, local de alta produção de oxigênio. A medida em que se aprofunda na lagoa, a energia luminosa diminui, reduzindo, em decorrência, a concentração de algas. Na camada superficial, com menos de $50 \mathrm{~cm}$, situa-se a faixa de maior intensidade luminosa, com o restante da lagoa praticamente escura.

Há um ponto ao longo da profundidade da lagoa em que a produção de oxigênio pelas algas se iguala ao consumo de oxigênio, pelas próprias algas e pelos microorganismos decompositores. Este ponto é denominado de oxipausa. (Sperling,1996)

$\mathrm{Na}$ Figura 1 são apresentados os fluxogramas dos sistemas de lagoas de estabilização mais utilizados. 
Sistema Australiano

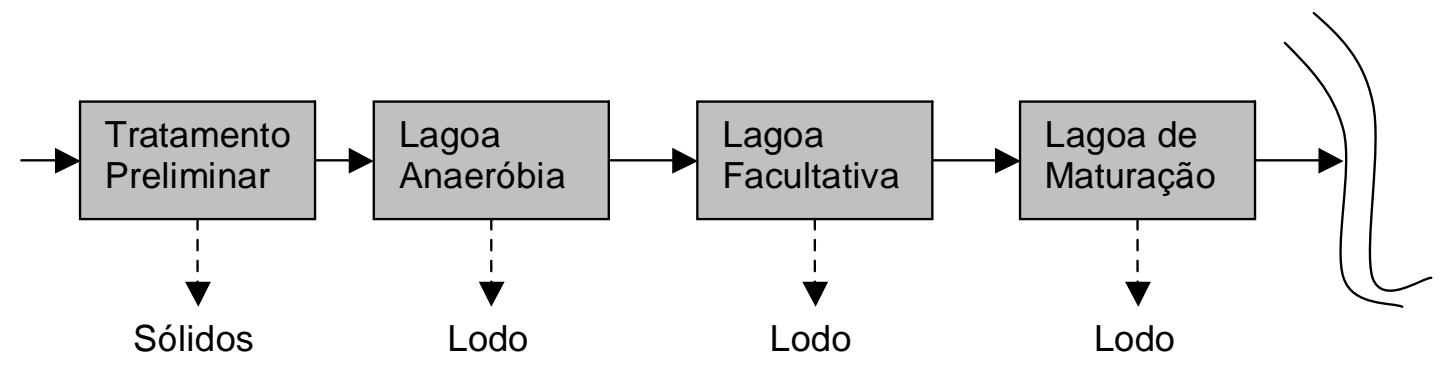

Sistema com Lagoa Facultativa Primária

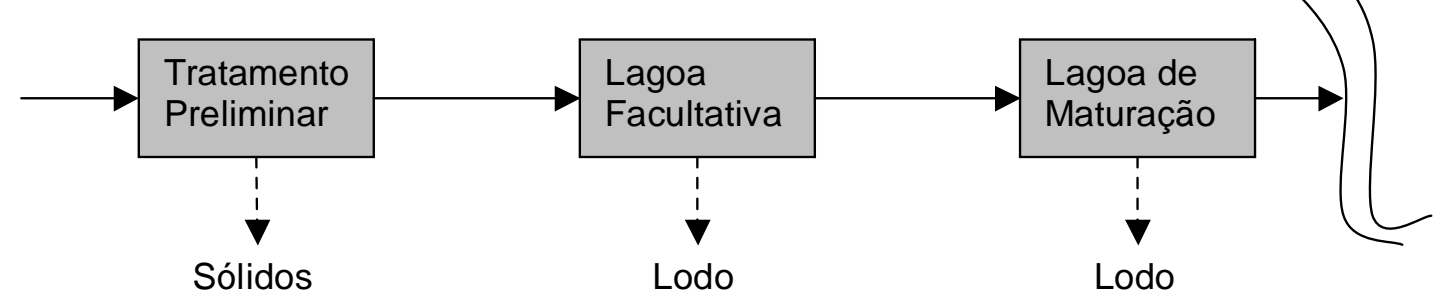

Figura 1: Fluxogramas dos Sistemas de Lagoas de Estabilização

\subsubsection{Lagoas Anaeróbias}

As Lagoas Anaeróbias são geralmente utilizadas precedendo lagoas de estabilização fotossintéticas. Não existe basicamente um limite de população para a sua utilização, desde que se tenha área e solo adequados à sua implantação. Quando se tem essas condições, as lagoas resultam no sistema de tratamento mais econômico e por isso mesmo são bastante utilizadas. Por problemas de odores, recomenda-se que as lagoas anaeróbias estejam a pelo menos 500 metros de residências. (Pivelli, 2003).

As lagoas anaeróbias apresentam, em geral, remoção de DBO na faixa de 40 a $70 \%$, produzindo um efluente com DBO na faixa mais usual de 70 a $160 \mathrm{mg} / \mathrm{L}$. (Pivelli, 2003).

São escavações com profundidade útil na faixa de 3 a 5 metros, recebendo carga contínua de esgoto de modo a manter condições de anaerobiose. A matéria 
orgânica é convertida primeiramente por bactérias facultativas a ácidos voláteis, como o ácido acético, e depois é definitivamente oxidada a metano e gás carbônico por bactérias anaeróbias estritas. O nitrogênio orgânico é oxidado a nitrogênio amoniacal e o nitrato pode ser reduzido a nitrogênio molecular, $\mathrm{N}_{2}$ gasoso. Os fosfatos orgânicos são oxidados a ortofosfatos. A geração de maus odores ocorre com a redução de sulfato a sulfeto, promovendo a liberação do gás sulfídrico, $\mathrm{H}_{2} \mathrm{~S}$. $\mathrm{Na}$ Figura 2 apresenta-se um esquema representativo do funcionamento de uma lagoa anaeróbia.

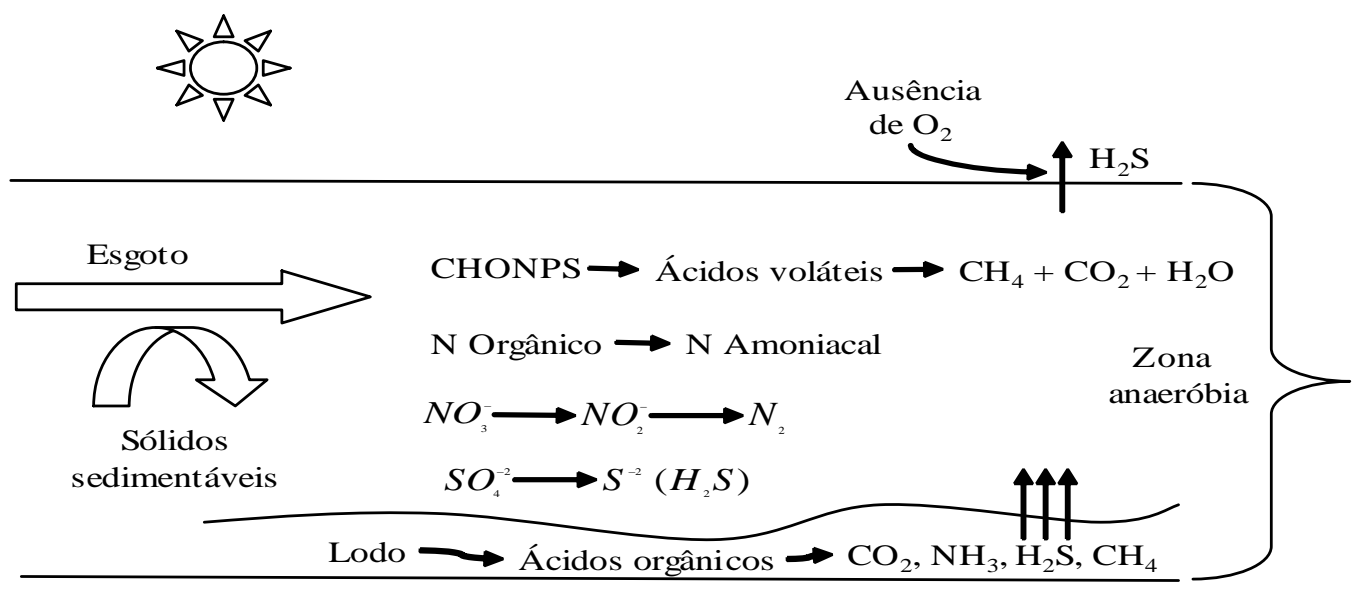

Figura 2: Transformações Bioquímicas em Lagoas Anaeróbias

No dimensionamento das lagoas anaeróbias, recomendam-se tempos de detenção hidráulicos na faixa de 3 a 6 dias, dependendo da temperatura local. A taxa de aplicação volumétrica de DBO deverá situar-se entre 0,1 e $0,4 \mathrm{~kg} \mathrm{DBO} / \mathrm{m}^{3}$.dia e a taxa de aplicação superficial de DBO deverá ser superior a 1000 kg DBO/ha.dia, para que se garanta anaerobiose. Nestas condições, eficiências na remoção de DBO na faixa de 40 a $60 \%$ podem ser esperadas (Pivelli, 2003).

Nos projetos, deve-se garantir a distribuição das entradas e das saídas dos esgotos, dificultando-se a ocorrência de caminhos preferenciais. O rebaixo adicional do fundo da lagoa até cerca de $1 / 4$ de seu comprimento resulta em um ganho de volume para acúmulo de lodo. A inclinação dos taludes a ser estabelecida depende dos estudos geotécnicos a serem feitos preliminarmente. 


\subsubsection{Lagoas Facultativas Fotossintéticas}

As lagoas facultativas são escavações com profundidades úteis na faixa de 1,5 a 2,0 metros, permitindo a penetração de luz e a produção de oxigênio via fotossíntese em quase toda sua extensão, utilizado pelos microrganismos heterotróficos na decomposição de matéria orgânica. Parte dos sólidos dos esgotos se sedimenta e entra em decomposição anaeróbia no fundo da lagoa, o que a torna facultativa. A ação de ventos sobre a superfície das lagoas também é importante para a oxigenação, o que torna desejável a manutenção de uma área livre em torno das lagoas. Na Figura 3, representam-se os principais mecanismos que ocorrem nas lagoas facultativas fotossintéticas.

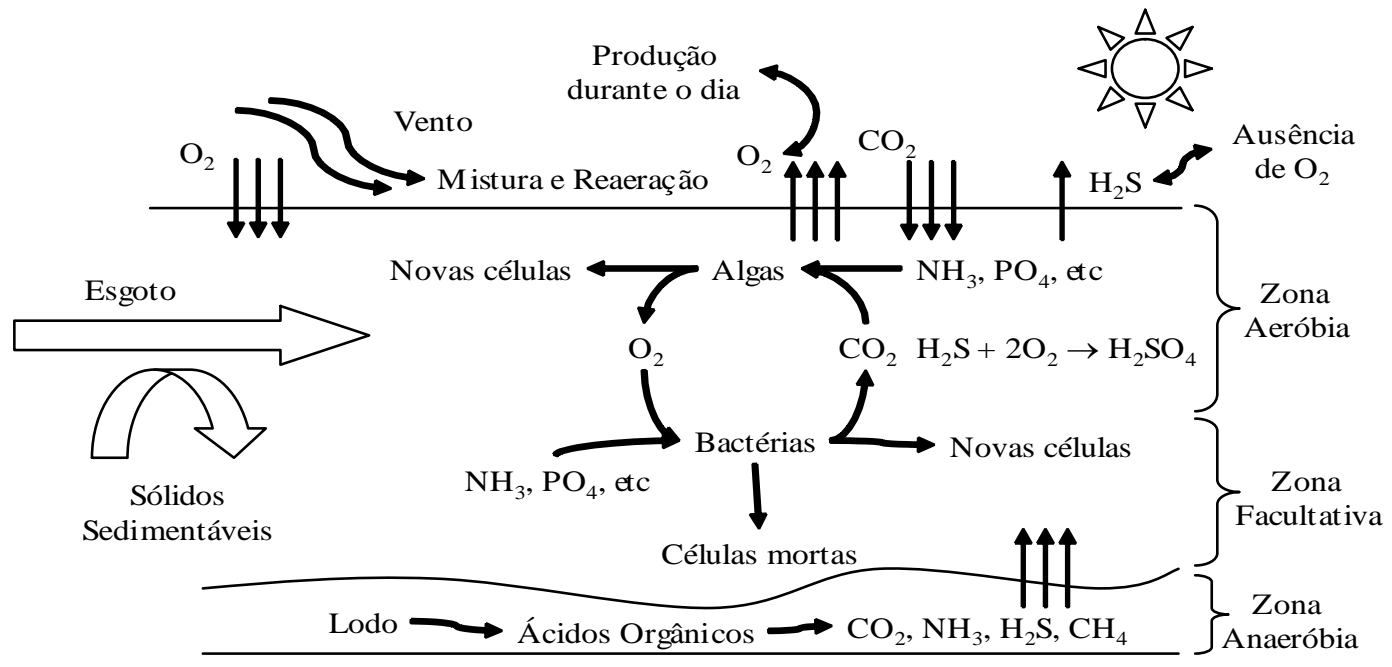

Figura 3: Transformações Bioquímicas em Lagoas Facultativas

A profundidade típica das lagoas facultativas primárias é de 1,80 m, podendo-se acrescentar um rebaixo de $0,5 \mathrm{~m}$ no quarto inicial do comprimento para acúmulo de lodo, uma vez que neste arranjo não se incluem lagoas anaeróbias a montante. A relação comprimento/largura varia normalmente na faixa de 3/1 a 5/1, embora esses limites possam ser ultrapassados. A profundidade típica das lagoas facultativas secundárias é de $1,50 \mathrm{~m}$. 


\subsubsection{Lagoas de Maturação}

São escavações com profundidades inferiores a 1,0 m, permitindo elevados tempos de detenção dos esgotos e o decaimento dos coliformes devido à incidência da radiação ultravioleta da luz solar. Os efluentes das lagoas facultativas são mais clarificados e assim ocorre boa penetração de luz. A baixa concentração de matéria orgânica biodegradável contribui para o decaimento por metabolismo endógeno. Promove boa nitrificação dos esgotos e pequeno aumento na remoção de $\mathrm{DBO}_{5}$. Obtém-se normalmente eficiências na remoção de coliformes fecais superiores a 99,99\%, com efluentes com concentrações de coliformes fecais inferiores a $10^{3}$ $\mathrm{CF} / 100 \mathrm{~mL}$. Em áreas densamente habitadas pode ser difícil a existência de área suficiente para a implantação de lagoas de maturação. Um tempo de detenção típico é de 7 dias para a obtenção das eficiências mencionadas, devendo-se recorrer aos modelos de decaimento de coliformes e aos padrões do corpo receptor para a definição do tempo de detenção hidráulico necessário. Na Figura 4 apresenta-se um esquema representativo do funcionamento das lagoas de maturação.

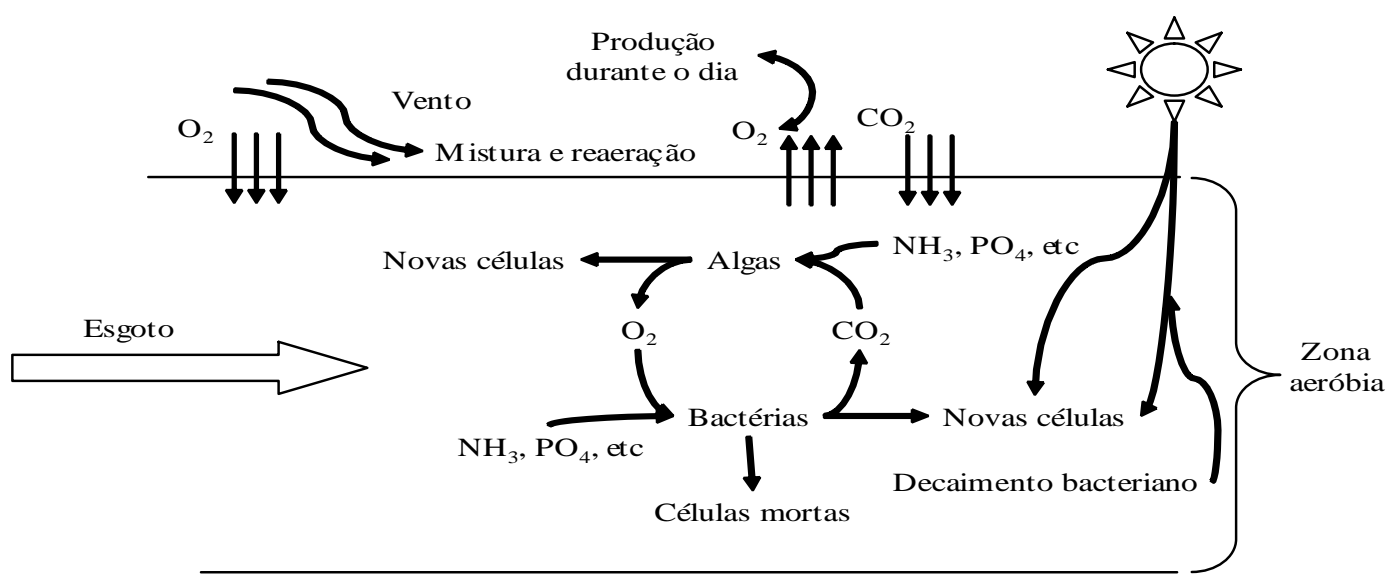

Figura 4: Transformações Bioquímicas em Lagoas de Maturação 


\subsubsection{Outras características dos Sistemas de Lagoas de Estabilização}

$\mathrm{Na}$ Tabela 4 apresenta-se uma síntese dos principais parâmetros utilizados para o projeto dos sistemas de lagoas de estabilização, válidos para as condições climáticas brasileiras. Esta Tabela serve como síntese dos parâmetros apresentados individualmente para cada tipo de lagoa, para a complementação e para servir como referência, por terem sido extraídos de outra fonte bibliográfica.

Tabela 4: Principais Parâmetros de Projeto de Lagoas de Estabilização.

\begin{tabular}{|c|c|c|c|}
\hline \multirow[b]{2}{*}{ Parâmetro de Projeto } & \multicolumn{3}{|c|}{ Tipo de Lagoas } \\
\hline & Anaeróbias & $\begin{array}{c}\text { Facultativas } \\
\text { Primárias }\end{array}$ & $\begin{array}{l}\text { Facultativas } \\
\text { Secundárias }\end{array}$ \\
\hline Tempo de detenção (d) & $3-6$ & $15-45$ & $10-30$ \\
\hline $\begin{array}{l}\text { Taxa de aplicação } \\
\text { superficial (kgDBO } \\
5 / \text { ha.d) }\end{array}$ & - & $100-350$ & $100-350$ \\
\hline $\begin{array}{l}\text { Taxa de aplicação } \\
\text { volumétrica }\left(\mathrm{kgDBO} / \mathrm{m}^{3} . \mathrm{d}\right)\end{array}$ & $0,10-0,35$ & - & - \\
\hline Profundidade $(\mathrm{m})$ & $3,0-5,0$ & $1,5-2,0$ & $1,5-2,0$ \\
\hline $\begin{array}{l}\text { Área "per capita" } \\
\text { requerida }\left(\mathrm{m}^{2} / \mathrm{hab} .\right)\end{array}$ & $0,1-0,2$ & $2,0-4,0$ & $1,5-3,0$ \\
\hline
\end{tabular}

Os sistemas de lagoas de estabilização têm sido amplamente utilizados na prática de tratamento de esgoto sanitário em todo o Brasil, tendo-se observado resultados 
satisfatórios em termos da qualidade do efluente, sempre quando o projeto é tecnicamente adequado e existe um mínimo de operação e manutenção.

Com relação aos constituintes físico-químicos dos esgotos, na Tabela 5 sintetizamse as faixas de eficiências de remoção que podem ser esperadas nas condições climáticas brasileiras, quando são aplicados os parâmetros de projeto anteriormente descritos.

Tabela 5: Faixas de Eficiências de Remoção de Constituintes Físico-Químicos em Lagoas de Estabilização.

\begin{tabular}{|c|c|c|c|c|}
\hline \multirow[b]{3}{*}{ Parâmetro } & \multicolumn{4}{|c|}{ Eficiência Típica de Remoção (\%) } \\
\hline & Lagoa & Lagoa & Lagoa & Lagoa \\
\hline & Facultativa & $\begin{array}{c}\text { Anaeróbia + } \\
\text { Facultativa }\end{array}$ & $\begin{array}{c}\text { Facultativa + } \\
\text { Maturação }\end{array}$ & $\begin{array}{c}\text { Anaeróbia + } \\
\text { Facultativa + } \\
\text { Maturação }\end{array}$ \\
\hline$\overline{\mathrm{DBO}}$ & $75-85$ & $75-85$ & $80-85$ & $80-85$ \\
\hline DQO & $65-80$ & $65-80$ & $70-83$ & $70-83$ \\
\hline SST & $70-80$ & $70-80$ & $70-80$ & $70-80$ \\
\hline Amônia & $<50$ & $<50$ & $40-80$ & $40-80$ \\
\hline Nitrogênio & $<60$ & $<60$ & $40-65$ & $40-70$ \\
\hline Fósforo & $<35$ & $<35$ & $>40$ & $>40$ \\
\hline
\end{tabular}

FONTE: Adaptada de Von Sperling (2003).

Apenas até as lagoas facultativas, isto é, quando não são implantadas as lagoas de maturação, os sistemas apresentam eficiências na remoção de $\mathrm{DBO}_{5}$ ligeiramente superiores a $80 \%$, com $\mathrm{DBO}_{5}$ dos efluentes inferiores a $60 \mathrm{mg} / \mathrm{L}$. A eficiência típica na remoção de coliformes fecais é de $99 \%$, com efluentes com concentrações da ordem de $10^{5} \mathrm{CF} / 100 \mathrm{~mL}$. A concentração de nitrogênio amoniacal pode ser superior a $15 \mathrm{mgN} / \mathrm{L}$ e a de fósforo total superior a $3 \mathrm{mgP} / \mathrm{L}$ Devido aos tempos de retenção elevados, o processo é bioquimicamente estável. Porém, os efluentes das lagoas facultativas sofrem variações de qualidade devido às mudanças na direção dos ventos e conseqüências sobre o acúmulo de algas na região da saída da lagoa. Destaca-se a baixa eficiência dos sistemas de lagoas de estabilização na remoção de nutrientes, nitrogênio e fósforo, o que é interessante sob o ponto de vista 
agronômico, mas que resulta na necessidade de tratamento complementar para lançamento em águas naturais.

Com relação aos constituintes microbiológicos dos esgotos, na Tabela 6 são apresentadas as faixas esperadas de eficiências de remoção.

Tabela 6: Faixas de Eficiências de Remoção de Organismos Patogênicos e Indicadores em Lagoas de Estabilização.

\begin{tabular}{|c|c|c|c|c|}
\hline \multirow[b]{2}{*}{ Parâmetro } & \multicolumn{4}{|c|}{ Eficiência Típica de Remoção (\% ou unidades log removidas)* } \\
\hline & $\begin{array}{c}\text { Lagoa } \\
\text { Facultativa }\end{array}$ & $\begin{array}{c}\text { Lagoa } \\
\text { Anaeróbia + } \\
\text { Facultativa }\end{array}$ & $\begin{array}{c}\text { Lagoa } \\
\text { Facultativa + } \\
\text { Maturação }\end{array}$ & $\begin{array}{c}\text { Lagoa } \\
\text { Anaeróbia + } \\
\text { Facultativa + } \\
\text { Maturação }\end{array}$ \\
\hline Coliformes & $1-2 \log$ & $1-2 \log$ & $3-6 \log$ & $3-6 \log$ \\
\hline $\begin{array}{l}\text { Bactérias } \\
\text { Patogênicas }\end{array}$ & $1-2 \log$ & $1-2 \log$ & $3-6 \log$ & $3-6 \log$ \\
\hline Vírus & $\leq 1 \log$ & $1 \log$ & $2-4 \log$ & $2-4 \log$ \\
\hline $\begin{array}{l}\text { Cistos de } \\
\text { Protozoários }\end{array}$ & $100 \%$ & $100 \%$ & $100 \%$ & $100 \%$ \\
\hline $\begin{array}{l}\text { Ovos de } \\
\text { Helmintos }\end{array}$ & $100 \%$ & $100 \%$ & $100 \%$ & $100 \%$ \\
\hline
\end{tabular}

Destaca-se a singular capacidade dos sistemas de lagoas de estabilização na remoção de contaminantes como os cistos de protozoários e ovos de helmintos, que normalmente se apresentam na forma de partículas que atingem a faixa coloidal. $O$ mecanismo de remoção predominante é a sedimentação. 
Se, por um lado, os sistemas de lagoas de estabilização são eficientes na remoção de sólidos em suspensão dos esgotos e operacionalmente simples, tendo em vista que o lodo formado se acumula e é digerido no fundo das lagoas, prescindindo da atividade cotidiana de tratamento de lodo, por outro, quando ocorrem as necessidades periódicas de remoção de lodo, tem-se um problema de grande porte. Esta atividade deverá ser adequadamente gerenciada, para que não seja admitido o acúmulo excessivo de lodo e a conseqüente queda na eficiência do processo de tratamento, bem como para que as alternativas de disposição final sejam convenientemente planejadas. Com o objetivo de subsidiar esta ação, na Tabela 7 são apresentadas as características quantitativas e qualitativas dos lodos acumulados em lagoas de estabilização.

Tabela 7: Taxas de acúmulo e características dos lodos de lagoas de estabilização.

\begin{tabular}{|c|c|c|c|c|}
\hline \multirow[b]{2}{*}{$\begin{array}{l}\text { Parâmetro de } \\
\text { Projeto }\end{array}$} & \multicolumn{4}{|c|}{ Tipo de Lagoas } \\
\hline & Anaeróbias & $\begin{array}{c}\text { Facultativas } \\
\text { Primárias }\end{array}$ & $\begin{array}{l}\text { Facultativas } \\
\text { Secundárias }\end{array}$ & Maturação \\
\hline $\begin{array}{l}\text { Taxa de acúmulo de } \\
\text { lodo ( } \mathrm{m}^{3} / \text { hab.ano) }\end{array}$ & $0,02-0,10$ & $0,03-0,09$ & $0,03-0,05$ & - \\
\hline $\begin{array}{l}\text { Intervalo de remoção } \\
\text { (anos) }\end{array}$ & $<7$ & $>15$ & $>20$ & $>20$ \\
\hline $\begin{array}{l}\text { Concentração de } \\
\text { sólidos totais no lodo } \\
(\% \text { ST })^{\star}\end{array}$ & $>10 \%$ & $>10 \%$ & $>10 \%$ & $>10 \%$ \\
\hline Relação SV / ST & $<50 \%$ & $<50 \%$ & $<50 \%$ & $<50 \%$ \\
\hline $\begin{array}{l}\text { Concentração de } \\
\text { coliformes fecais no } \\
\text { lodo (CF/gST) }\end{array}$ & $10^{2}-10^{4}$ & $10^{2}-10^{4}$ & $10^{2}-10^{4}$ & $10^{2}-10^{4}$ \\
\hline $\begin{array}{l}\text { Concentração de } \\
\text { ovos de helmintos no } \\
\text { lodo (ovos/gST) }\end{array}$ & $10^{1}-10^{3}$ & $10^{1}-10^{3}$ & $10^{1}-10^{3}$ & $10^{1}-10^{3}$ \\
\hline
\end{tabular}


Deve ser lembrado que é essencial à presença de um sistema bem operado de desarenação do esgoto. Deve ser lembrado também que, ao ser removido por dragagem hidráulica (bombeamento), a concentração de sólidos no lodo pode-se reduzir a $5 \%$ a $7 \%$.

\subsection{Cianobactérias (Cianofíceas)}

Cianobactérias são microrganismos procariontes (possuem o núcleo disseminado no protoplasma), que através de reações fotossintéticas liberam oxigênio molecular para a atmosfera. Várias espécies de cianobactérias podem apresentar um crescimento exagerado (florações) em corpos d’água superficiais como rios, lagos, reservatórios artificiais e lagoas de estabilização (Agujaro et al.,2006).

Cianobactérias também conhecidas como algas azuis, devendo seu nome a um dos principais pigmentos (pigmentos são compostos químicos que refletem e absorvem comprimentos de onda específicos da luz visível, o que confere coloração ao organismo) a ficocianina, que, juntamente com os demais pigmentos como a clorofila-a, ficoeritrina e ficobilissomas, conferem a estes organismos coloração azulesverdeada.

Outra característica interessante é que as cianobactérias podem apresentar aerótopos (vacúolos gasosos) que se acumulam principalmente em células mais velhas. Geralmente são envolvidas por uma massa gelatinosa ou revestidas por uma bainha mucilaginosa (Agujaro et al.,2006).

A origem das cianobactérias é estimada em cerca de 3,5 bilhões de anos pela descoberta de fósseis do que foram certamente esses microorganismos, em rochas sedimentares encontradas no noroeste da Austrália. As cianobactérias estão, portanto, entre os organismos pioneiros na Terra, sendo provavelmente os primeiros produtores primários de matéria orgânica a liberarem oxigênio elementar na atmosfera primitiva (Azevedo,1998). 
As florações de cianobactérias podem causar gosto e odor desagradável na água, além de alterar o equilíbrio ecológico do ecossistema aquático. No entanto, o mais grave é que certas espécies são capazes de produzir toxinas que podem ser acumuladas na rede trófica e produzir diferentes sintomas de intoxicação, atingindo conjuntos de organismos muito além da comunidade aquática.

Entre as cianobactérias que podem causar florações em corpos de água continentais, destacam-se aquelas que produzem as cianotoxinas. As cianotoxinas são liberadas para o ambiente quando as células se rompem. As cianotoxinas produzem efeitos especiais nos mamíferos, sendo classificadas como neurotoxinas e hepatotoxinas (Bittencourt et al.,2001).

Um exemplo emblemático do impacto à saúde a respeito das cianotoxicinas (hepatoxinas), foi a morte de mais de 60 pacientes em uma clínica de hemodiálise em Caruaru, Pernambuco, em 1996 (Jochimsen et al.,1998 apud Azevedo).

Em determinadas condições ambientais, tais como temperaturas médias diárias acima de $25{ }^{\circ} \mathrm{C}$, concentrações de nutrientes numa razão N:P (nitrogênio:fósforo) entre 20:1 e 10:1 e pH acima de 7,5, algumas populações de cianobactérias apresentam um intenso crescimento, conhecido como florações, as quais podem ser fenômenos naturais regionais de ocorrência sazonal, mas que, na maior parte das vezes, estão relacionadas a eutrofização artificial causada por excesso de nutrientes vindos de efluentes domésticos e rejeitos industriais (Bittencourt et al.,2001).

Como as cianobactérias estão entre os mais antigos organismos do planeta, por isso, possuem uma gama de características que lhes conferem algumas vantagens na sua dispersão e predominância nos mais diversos habitats do planeta (Agujaro e Carvalho, 2004):

- Apresentam mecanismos de proteção do DNA contra radiação UV.

- Suportam baixa concentração de oxigênio dissolvido

- Acumulam grânulos de polifosfato como reserva

- Apresentam adaptação cromática

- Regulam mobilidade e flutuabilidade pela presença dos aerótopos

- Liberam toxicinas como possível proteção a predação. 
A Figura 5 apresenta os principais gêneros e espécies nocivas de cianobactérias, como extraído de Chorus e Bartram, 1999 e adaptado pela UPC - UNIDADE DE PESQUISA EM CIANOBACTÉRIAS - Fundação Universidade Federal do Rio Grande - FURG/RS

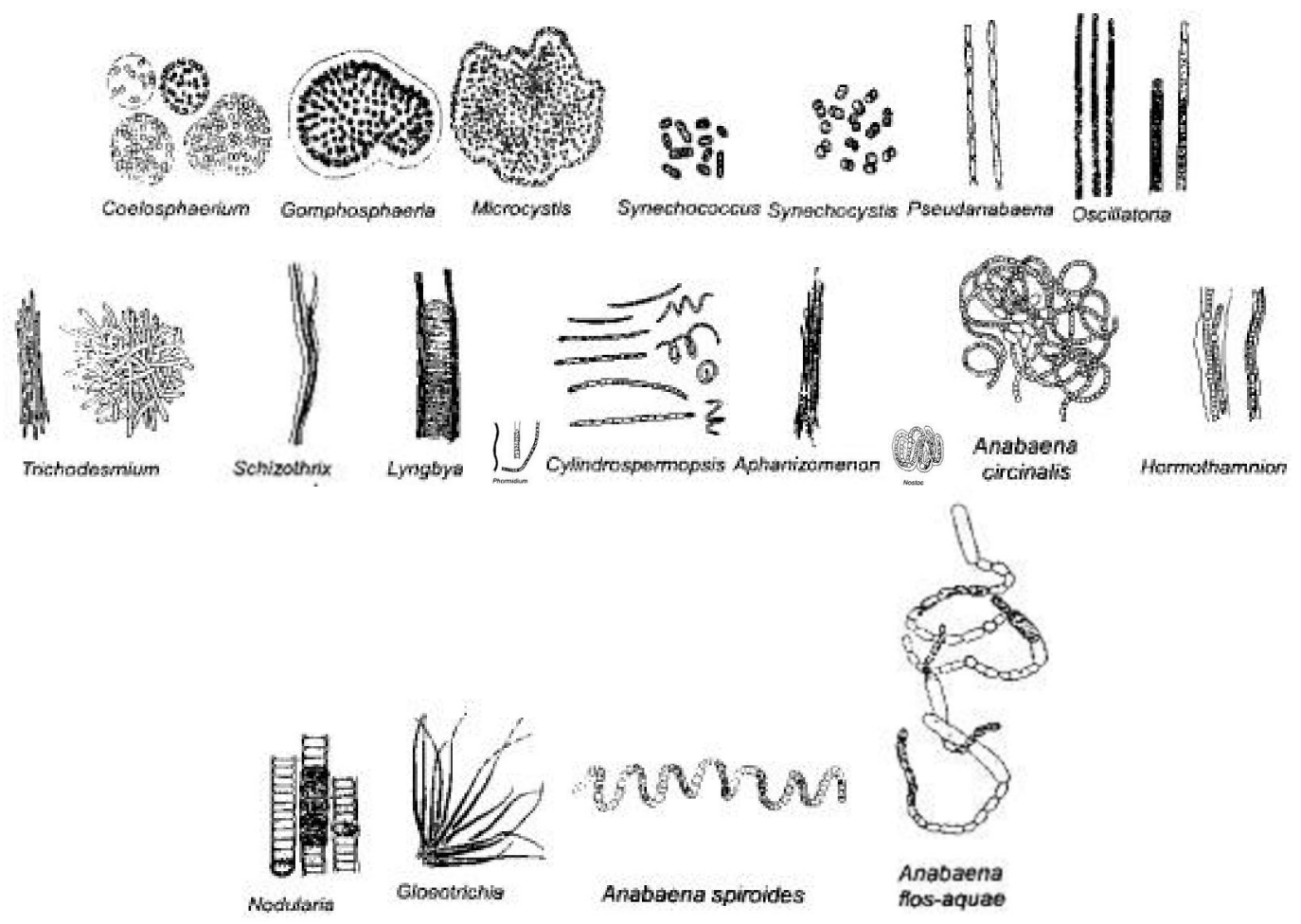

Figura 5: principais gêneros e espécies de cianobactérias nocivas (Chorus e Bartram, 1999)

\subsection{Pós Tratamento com Processo Físico-químico}

A adição de reagentes químicos ao esgoto com o objetivo de promover a coagulação química e a floculação, e acelerar a sedimentação, vem constituindo uma prática crescente no tratamento primário de esgotos, recebendo esta designação de tratamento Primário Quimicamente Assistido - TPQA. Tem sido muito comum o uso da terminologia em inglês - Chemical Enhanced Primary Treatment CEPT (Jordão e Pacheco, 2005). 
Apesar de não ser uma idéia nova, data de mais de 100 anos, quase não há sistemas implantados no Brasil. O TPQA utiliza o princípio da coagulação floculação, muito utilizado para tratamento de água, através da aplicação de sais de ferro ou alumínio (cloreto férrico, sulfato de alumínio, sulfato ferroso, etc.) seguido ou não de polímero, como também utilizando somente o polímero como coagulante, com o intuito de promover a remoção da DBO, SS, e Nutrientes - N e P. O CEPTTPQA permite depurar significativamente as principais classes de poluentes do esgoto numa única etapa de tratamento, além de apresentar vários atributos exclusivos.

O processo físico-químico pode ser aplicado ao início, ao meio ou ao final do tratamento do esgoto. Entretanto, a estratégia que propicia os maiores benefícios econômicos e ambientais é a sua aplicação no início ou como etapa única do tratamento de esgoto, tratando desde o esgoto de condomínios, hotéis e hospitais, até as mega-cidades com mais de 20 milhões de habitantes (Tsukamoto, 2003).

No tratamento físico-químico, resultados típicos de eficiências encontradas em relação a DBO são da ordem de 45 a 55\% e SST da ordem de 70 a $85 \%$.

Pode-se elencar inúmeras vantagens do processo CEPT, que seguem abaixo, conforme citado por Jordão et al, 2005:

- Maior eficiência de remoção de SST e DBO;

- Possível remoção de fósforo, de acordo com a dosagem;

- menor número de decantadores;

- menor área ocupada;

- possível controle de odores na entrada da ETE;

- sendo menor a carga afluente á fase de tratamento secundário, os tanques de aeração serão menores, assim como a potencia instalada e a energia consumida;

- menor custo de investimento inicial.

Assim, como se pode elencar algumas desvantagens sobre o processo CEPT, que seguem abaixo: 
- custos operacionais;

- operação e manuseio de reagentes químicos;

- maior geração de lodo primário;

- maiores custos de instalação e operação das unidades de tratamento de lodo.

\subsection{Apresentação e discussão sobre a resolução CONAMA № $357 / 05$}

A resolução CONAMA № 357/05, que "dispõe sobre a classificação dos corpos de água e diretrizes ambientais para o seu enquadramento, bem como estabelece as condições e padrões de lançamento de efluentes, e dá outras providências", substitui a antiga resolução CONAMA 20/86.

Dentre as principais diferenças entre as duas resoluções em relação ao presente estudo, destacam-se a inclusão dos parâmetros:

- densidade de cianobactérias;

- concentração de clorofila-a.

- Nitrogênio amoniacal total

- Fósforo total

Observa-se, então, os seguintes limites na nova CONAMA № 357/05 para águas naturais:

Densidade de cianobactérias:

- $20000 \mathrm{cel} / \mathrm{mL}$ ou $2 \mathrm{~mm}^{3} / \mathrm{L}$ para águas doces de classe 1 ;

- $50000 \mathrm{cel} / \mathrm{mL}$ ou $5 \mathrm{~mm}^{3} / \mathrm{L}$ para águas doces de classe 2;

- $100000 \mathrm{cel} / \mathrm{mL}$ ou $10 \mathrm{~mm}^{3} / \mathrm{L}$ para águas doces de classe 3 .

Concentração de clorofila a em águas naturais:

- $10 \mu \mathrm{g} / \mathrm{L}$ para águas doces de classe 1; 
- $30 \mu \mathrm{g} / \mathrm{L}$ para águas doces de classe 2;

- $60 \mu \mathrm{g} / \mathrm{L}$ para águas doces de classe 3.

Nitrogênio Amoniacal Total:

Classe 1 e 2

- $3,7 \mathrm{mg} / \mathrm{LN}$ para $\mathrm{pH} 7,5$

- $2,0 \mathrm{mg} / \mathrm{LN}$ para $7,5<\mathrm{pH}<8,0$

- $1,0 \mathrm{mg} / \mathrm{LN}$ para $8,0<\mathrm{pH}<8,5$

- $0,5 \mathrm{mg} / \mathrm{LN}$ para $\mathrm{pH}>8,5$

Classe 3

- $13,3 \mathrm{mg} / \mathrm{LN}$ para $\mathrm{pH} 7,5$

- $5,6 \mathrm{mg} / \mathrm{LN}$ para $7,5<\mathrm{pH}<8,0$

- $2,2 \mathrm{mg} / \mathrm{LN}$ para $8,0<\mathrm{pH}<8,5$

- $1,0 \mathrm{mg} / \mathrm{LN}$ para $\mathrm{pH}>8,5$

Os limites de amônia são estabelecidos em função do $\mathrm{pH}$ em vista que em quanto mais elevado o pH maior é a parcela de amônia gasosa, $\mathrm{NH}_{3}$, que é mais tóxica. $\mathrm{O}$ íon amônio, $\mathrm{NH}_{4}{ }^{+}$, menos tóxico, predomina em faixas mais baixas de $\mathrm{pH}$.

fósforo total:

Classe 1

a) até $0,020 \mathrm{mg} / \mathrm{L}$, em ambientes lênticos; e,

b) até $0,025 \mathrm{mg} / \mathrm{L}$, em ambientes intermediários, com tempo de residência entre 2 e 40 dias, e tributários diretos de ambiente lêntico.

c) até $0,1 \mathrm{mg} / \mathrm{L}$, em ambiente lótico e tributários de ambientes intermediários.

Classe 2

a) até $0,030 \mathrm{mg} / \mathrm{L}$, em ambientes lênticos; e,

b) até $0,050 \mathrm{mg} / \mathrm{L}$, em ambientes intermediários, com tempo de residência entre 2 e 40 dias, e tributários diretos de ambiente lêntico.

c) até $0,1 \mathrm{mg} / \mathrm{L}$, em ambiente lótico e tributários de ambientes intermediários. 


\section{Classe 3}

a) até $0,05 \mathrm{mg} / \mathrm{L}$, em ambientes lênticos; e,

b) até $0,075 \mathrm{mg} / \mathrm{L}$, em ambientes intermediários, com tempo de residência entre 2 e 40 dias, e tributários diretos de ambiente lêntico.

c) até $0,15 \mathrm{mg} / \mathrm{L}$, em ambiente lótico e tributários de ambientes intermediários.

Existe uma dificuldade dos sistemas de lagoas em atender a esses limites apresentados acima para estes parâmetros, cianobactéria e clorofila-a, nitrogênio e fósforo, necessitando de graus de diluição muitas vezes indisponíveis ou póstratamento sofisticados, como os de natureza físico-química. O outro lado da discussão é que apesar destas dificuldades os sistemas de lagoas constituem importante opção de tratamento, sobretudo para pequenas comunidades em países em desenvolvimento e de clima quente.

Seguem alguns exemplos de padrão:

Padrões de qualidade - Águas Doces Classe 1 Resolução CONAMA 357/2005

- $\mathrm{pH}$ : entre 6 e 9

- Oxigênio Dissolvido: não inferior a 5,0 mg/L

- $\mathrm{DBO}_{5,20}$ : inferior a $5,0 \mathrm{mg} / \mathrm{L}$

- Coliformes Totais: não superior a 5.000/ $100 \mathrm{~mL}$

- Coliformes Fecais: não superior a $1.000 / 100$ mL

Em vista disto, cabe um estudo para identificação, quantificação de densidade de cianobactérias e clorofila-a em correlação com outros indicativos, para o sistema em estudo que possui a peculiaridade de ser tratamento por lagoas de estabilização associadas a tratamento físico-químico. 


\section{MATERIAS E MÉTODOS}

\section{1. $\quad$ Descrição do Sistema de Tratamento de Efluentes}

Na Figura 6, apresenta-se a localização da Riviera de são Lourenço e seu sistema de tratamento de efluentes.

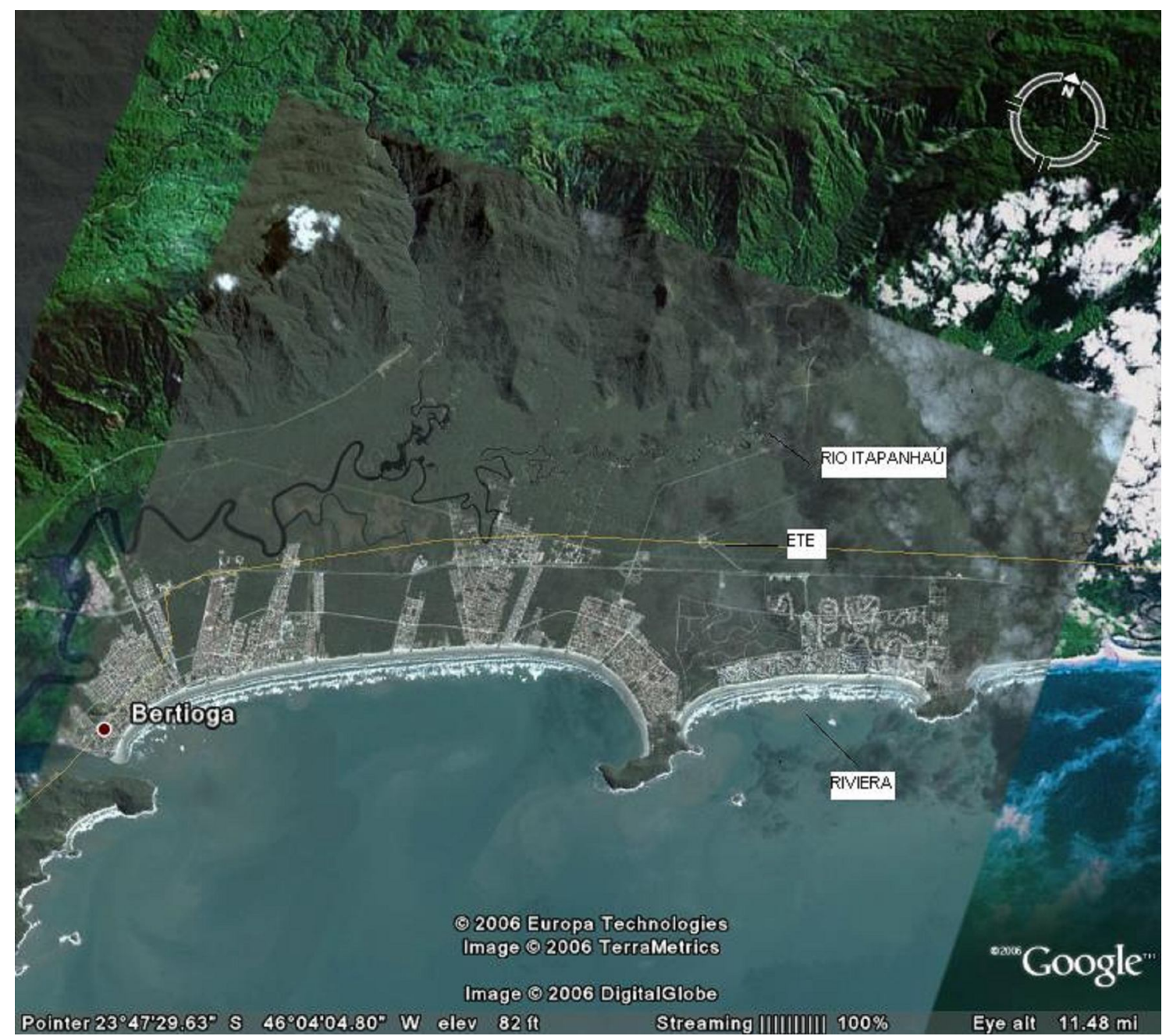

Figura 6: Foto da Localização do sistema de tratamento de efluentes da Riviera de São Lourenço Bertioga - SP.

A Riviera de São Lourenço localiza-se no município de Bertioga, litoral norte do estado de São Paulo. O sistema de tratamento de efluentes está situado às margens da rodovia Rio-Santos, a aproximadamente $2,5 \mathrm{~km}$ do empreendimento. 
Inicialmente foi concebido como um tratamento biológico (sistema australiano); uma lagoa anaeróbia seguida de duas lagoas facultativas, já reservando espaço físico para construções de mais lagoas. Em 1998 foi construída mais uma lagoa facultativa ao lado das outras duas existentes e praticamente com a mesma capacidade volumétrica, com todas trabalhando em paralelo.

Com o contínuo crescimento do empreendimento Riviera, se fez necessário novamente à ampliação do sistema em 1999, pois, a capacidade de tratamento estava começando a saturar para a ocupação máxima e havia o problema da sazonalidade, ou seja, as lagoas recebiam uma carga muito grande em função do aumento da população, motivado por um feriado, férias de fim de ano ou fim de semana de muito sol.

Utilizou-se, então, para uma segunda ampliação, o sistema de tratamento físicoquímico também conhecido como CEPT (Chemically Enhanced Primary Treatment) ou TPQA (tratamento primário quimicamente assistido), sendo o primeiro sistema implantado no Brasil. Tal sistema ocupa pouco espaço físico e pode-se utilizar a aplicação de produtos químicos somente na alta temporada. O TPQA é um tratamento que utiliza o princípio da coagulação - floculação, muito utilizado para tratamento de água, através da aplicação de um sal férrico que no caso da Rivera de São Lourenço foi o cloreto férrico $(40 \mathrm{mg} / \mathrm{l})$ e um polímero aniônico $(0,5 \mathrm{mg} / \mathrm{l})$, com o intuito de promover a remoção da DBO, SST, e Nutrientes - N e P. Sendo assim, ele seria posto em operação sempre que a ocupação superasse a capacidade de tratamento das lagoas.

\subsubsection{Descrição atualizada da ETE da Riviera de São Lourenço}

Atualmente, o sistema de operação sofreu novas alterações, visando aumentar o desempenho operacional da estação de tratamento de esgotos sanitários da Riviera de São Lourenço durante o ano de 2005, para atendimento ao crescimento populacional e com o intuito de se adequar nova legislação CONAMA 357/2005, foram concebidas, projetadas e implantadas novas unidades, resultando para a ETE 
- RSL (Estação de tratamento de esgoto da Riviera de São Lourenço) a conFiguração ilustrada no Fluxograma de Processo apresentado na Figura 7.

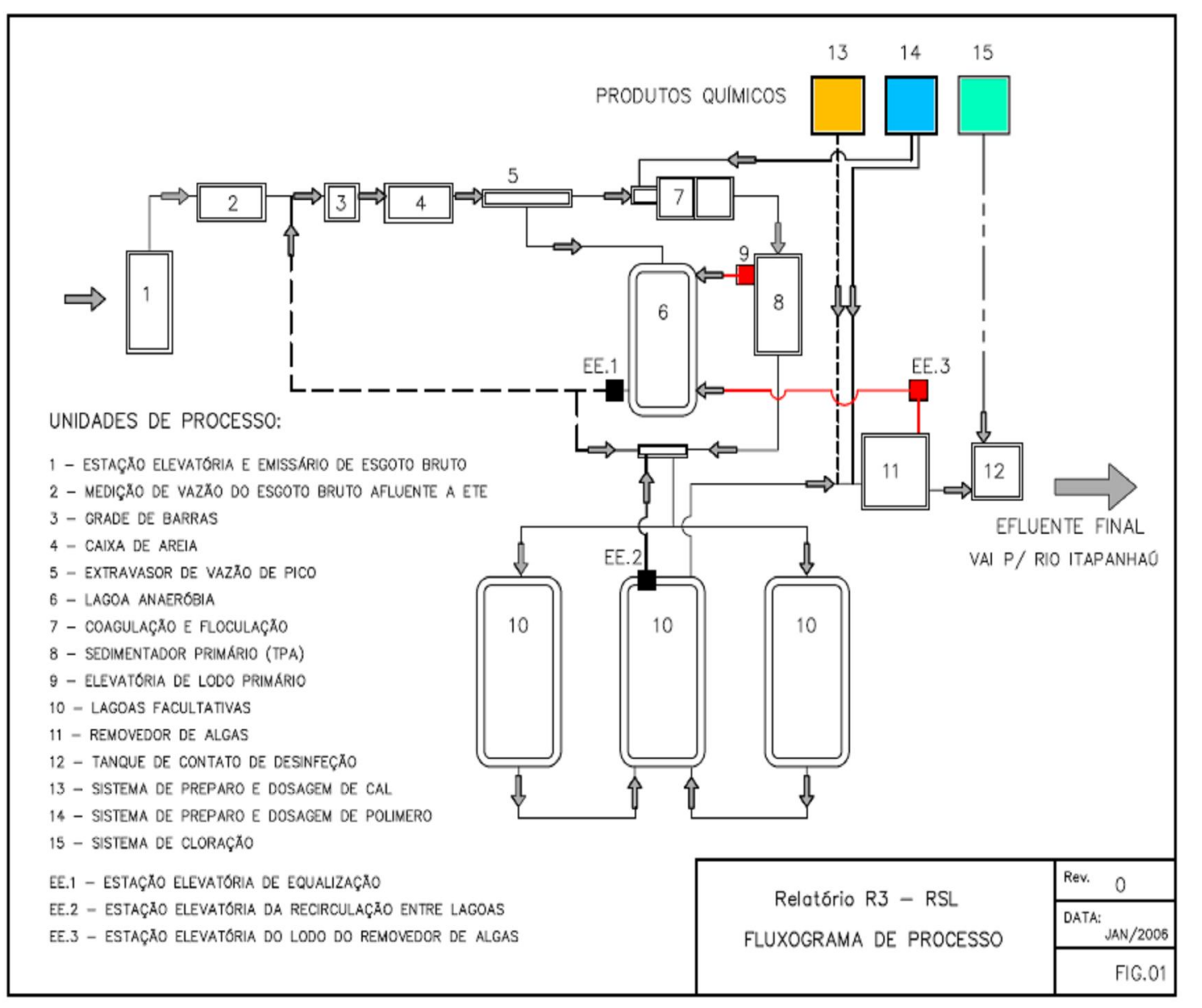

Figura 7: Fluxograma do sistema operacional de Tratamento de Esgotos da Riviera de São Lourenço.

\subsubsection{Estação elevatória e emissário de esgoto bruto}

Esta unidade permaneceu sem alterações, e é composta por quatro conjuntos motor-bomba submersíveis de rotação fixa.

-B1 - Vazão Nominal - $600 \mathrm{~m}^{3} / \mathrm{h}$

-B2 - Vazão Nominal - $600 \mathrm{~m}^{3} / \mathrm{h}$

- B3 - Vazão Nominal - $1080 \mathrm{~m}^{3} / \mathrm{h}$

-B4 - Vazão Nominal - 380 $\mathrm{m}^{3} / \mathrm{h}$ 
Na Figura 8, apresenta-se Estação Elevatória de Esgotos Final da Riviera de São Lourenço.

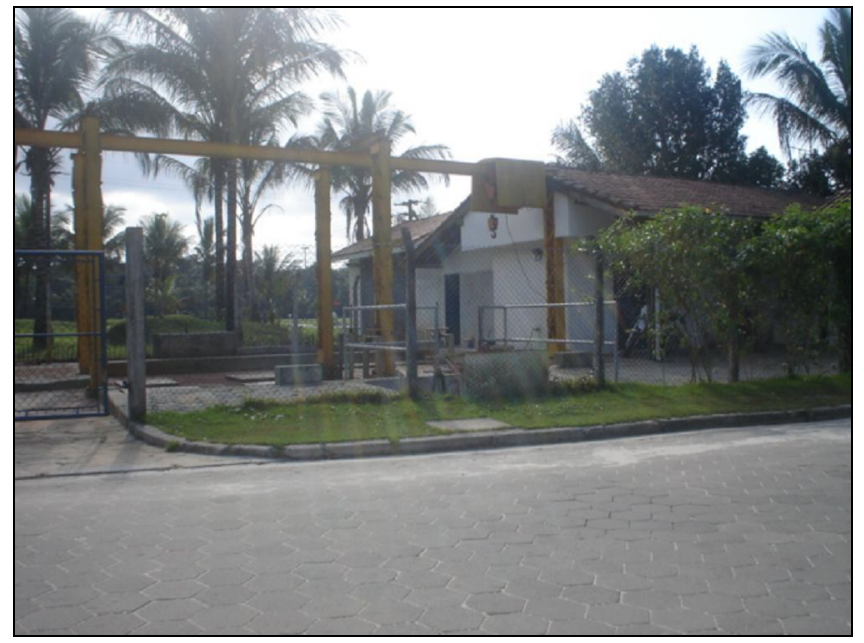

Figura 8: Estação Elevatória de Esgotos Final da Riviera de São Lourenço

A elevatória final recebe todo o esgoto da Riviera e bombeia para ETE-RSL

\subsubsection{Medição de vazão do esgoto bruto afluente a ETE}

A medição de vazões é realizada por meio de calha Parshall de 24" e sensor ultrasônico de nível.(Figura 9)

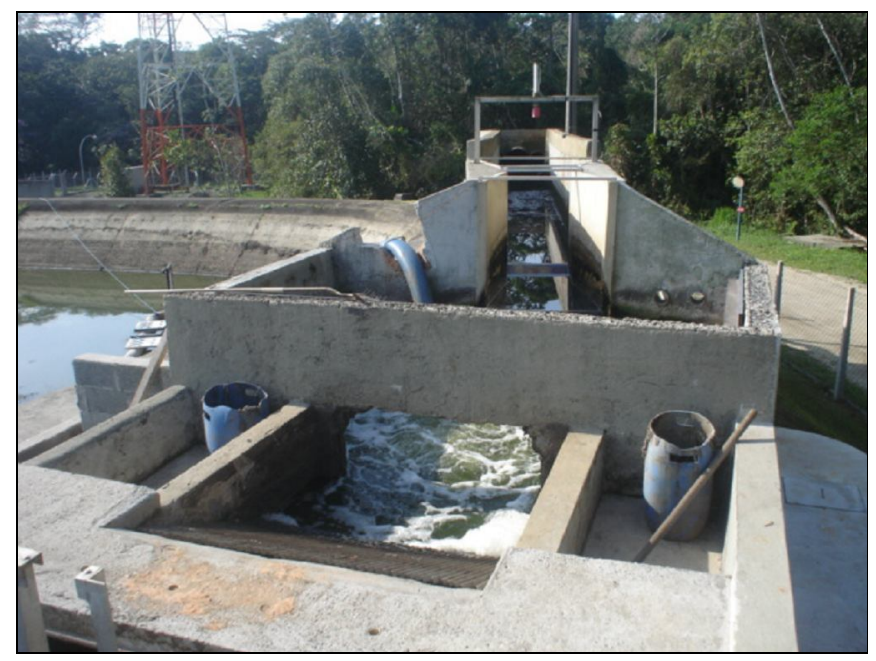

Figura 9: Calha de entrada e gradeamento da Estação de Tratamento de Esgoto da Riviera de São Lourenço. 


\subsubsection{Grade de barras}

O gradeamento é constituído de uma grade de barras de limpeza manual com espaçamento de $15 \mathrm{~mm}$ entre barras.

\subsubsection{Caixa de areia}

Esta unidade permaneceu sem alterações, sendo composta de caixa de areia de fluxo horizontal, com dois canais, e remoção manual de areia.(Figura 10)

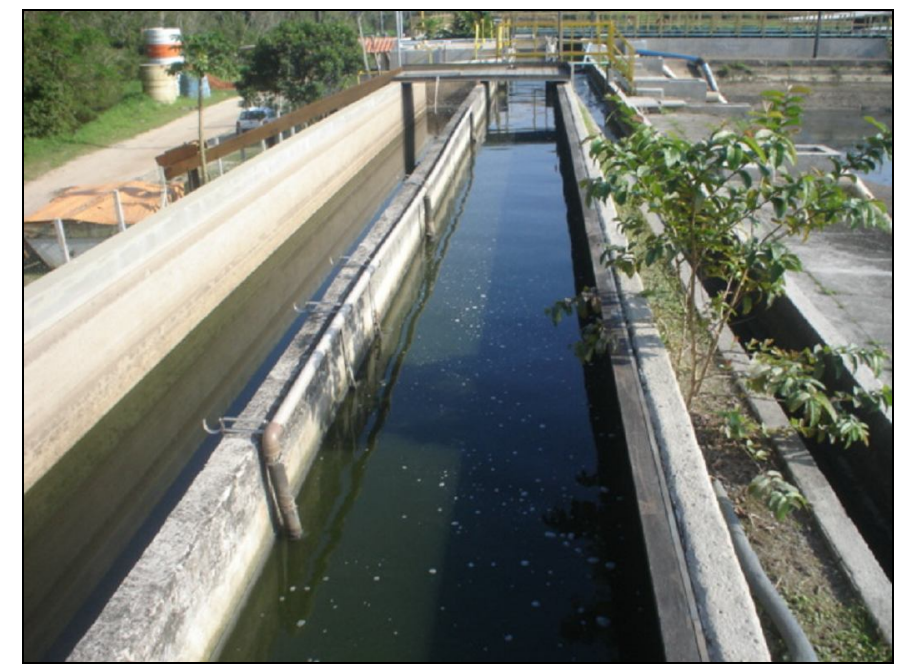

Figura 10: Caixa de Areia da Estação de Tratamento de Esgoto da Riviera de São Lourenço.

\subsubsection{Extravasor de vazões de pico}

$\mathrm{Na}$ Figura 11, apresenta-se o extravasor lateral de vazões de pico, tendo sido projetado e implantado para receber os picos de vazão que ocorrem durante o período do reveillon.

Trata-se de vertedor regular regulável com soleira de 10 metros de extensão, posicionado a montante da coagulação/floculação do TPQA e o volume extravasado fica estocado em volume de espera na Lagoa Anaeróbia. 


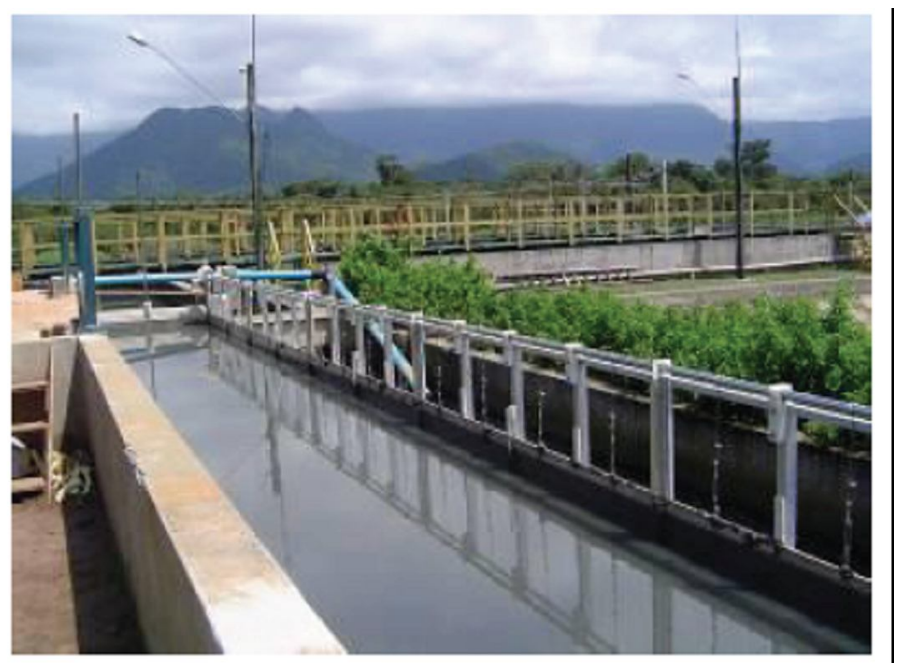

Figura 11: Extravasor de pico da Estação de Tratamento de Esgoto da Riviera de São Lourenço.

\subsubsection{Lagoa anaeróbia - LA}

A LA não sofreu alterações físicas, mas passou a ser operada como tanque pulmão para estocar volumes de esgoto gerados por vazões de pico de curta duração que ocorrem no reveillon - especialmente durante os dias 30,31 de dezembro e $1^{\circ}$ de janeiro.

Com esta forma de operação as unidades de jusante - floculadores, sedimentadores e lagoas facultativas - puderam ser projetadas e operadas para atender a vazão média destes dias críticos.

A LA tem um volume útil total de cerca de $25.000 \mathrm{~m}^{3}$; deste total $20.000 \mathrm{~m}^{3}$ são esvaziados gradativamente, devendo este volume estar disponível para receber os volumes extravasados no período de reveillon e início de janeiro.

Os $5.000 \mathrm{~m}^{3}$ do fundo são reservados para lodos em digestão, oriundos do sedimentador primário e do Decantador de algas. 
Na Figura 12, apresenta-se a Lagoa Anaeróbia da Estação de Tratamento de Esgoto da Riviera de São Lourenço

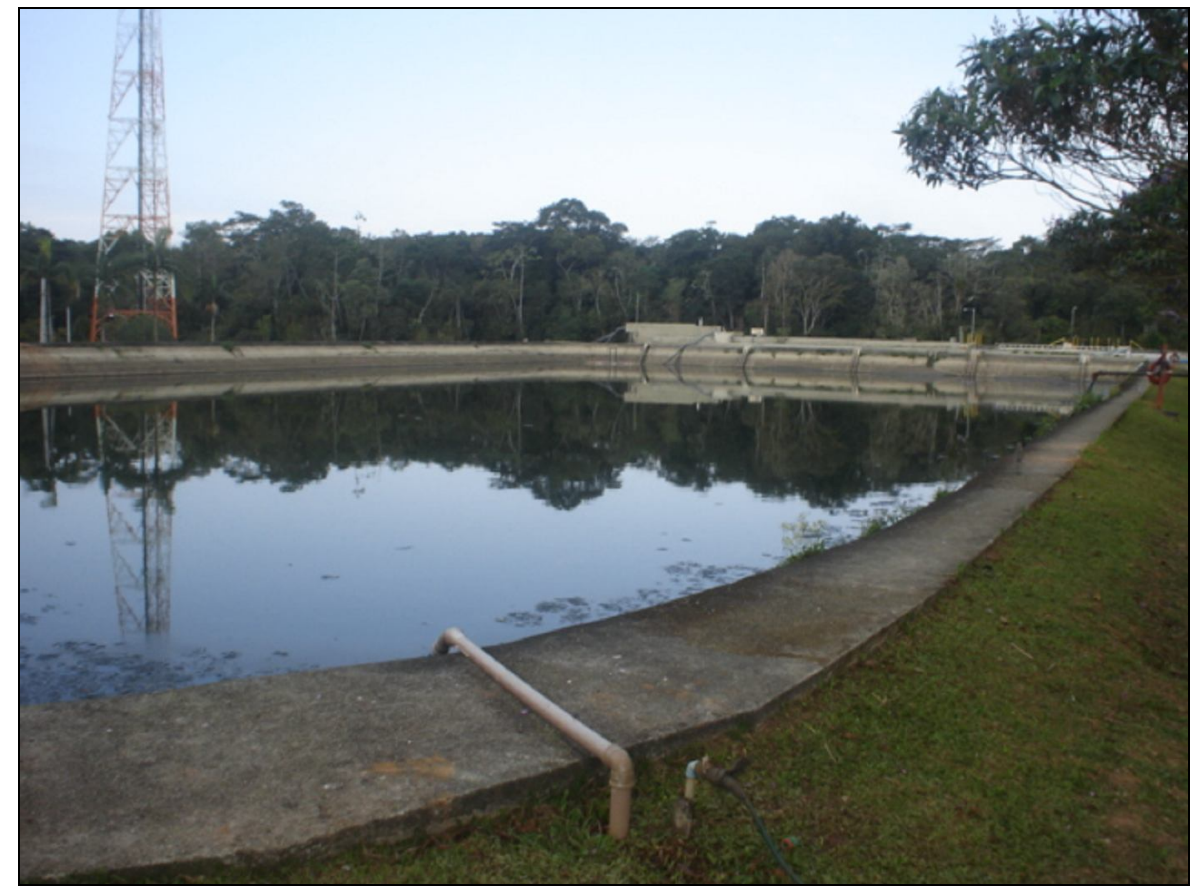

Figura 12: Lagoa Anaeróbia da Estação de Tratamento de Esgoto da Riviera de São Lourenço.

\subsubsection{Coagulação/floculação escalonada}

Após extravazão de vazões de pico o fluxo de esgoto bruto regularizado é coagulado e floculado, seguindo para a sedimentação.

É utilizado polímero catiônico aplicado por bombas dosadoras em canal de mistura rápida com chicanas, seguido por câmaras de floculação escalonada, misturadas mecanicamente

Este processo é realizado de acordo com os seguintes parâmetros operacionais:

- Dosagem de polímero catiônico : 3 a $4 \mathrm{mg} / \mathrm{L}$

- Mistura rápida : gradiente máximo de $800 \mathrm{~s}^{-1}$

- $1^{\text {a }}$ câmara de floculação : gradientes entre 50 e $230 \mathrm{~s}^{-1}$

- $2^{\mathrm{a}}$ câmara de floculação : gradientes entre 50 e $230 \mathrm{~s}^{-1}$ 
Na Figura 13, apresentam-se os floculadores do TPQA da Estação de Tratamento de Esgoto da Riviera de São Lourenço

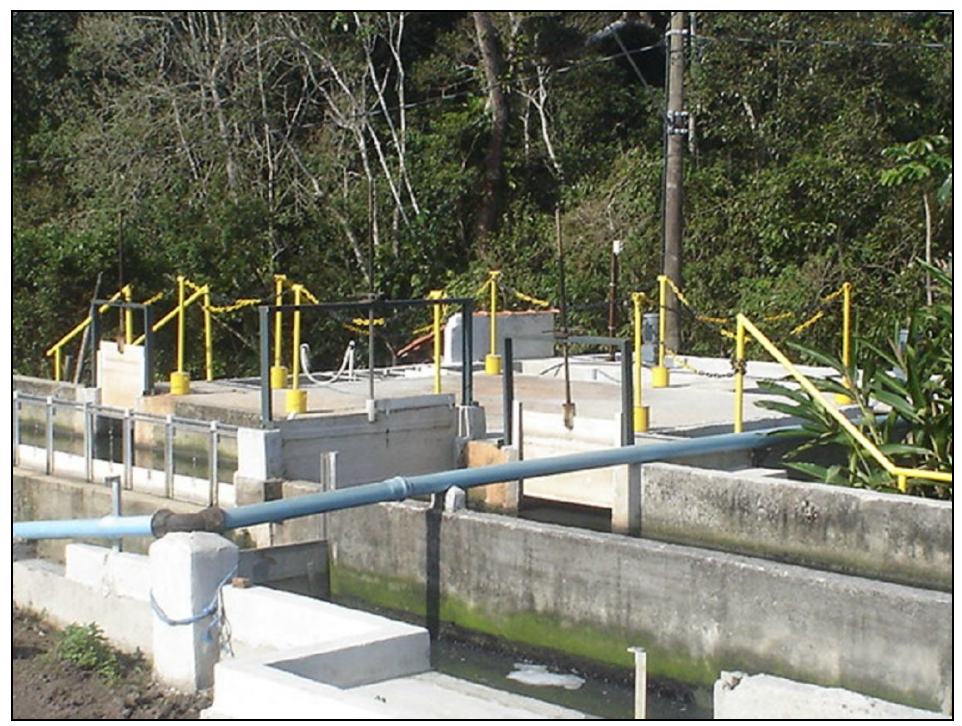

Figura 13: Floculadores do TPQA da Estação de Tratamento de Esgoto da Riviera de São Lourenço.

\subsubsection{Sedimentadores primários -TPQA}

Estas unidades permaneceram sem alterações físicas essenciais, com exceção de pequenas modificações das cortinas de entrada.

Dois sedimentadores de fluxo horizontal dotados de raspadores mecanizados de correntes e com as seguintes características unitárias:

- Área superficial útil: $180 \mathrm{~m}^{2}$

- Volume útil total: $575 \mathrm{~m}^{3}$

Na Figura 14, apresentam-se os sedimentadores Primários - TPQA da Estação de Tratamento de Esgoto da Riviera de São Lourenço. 


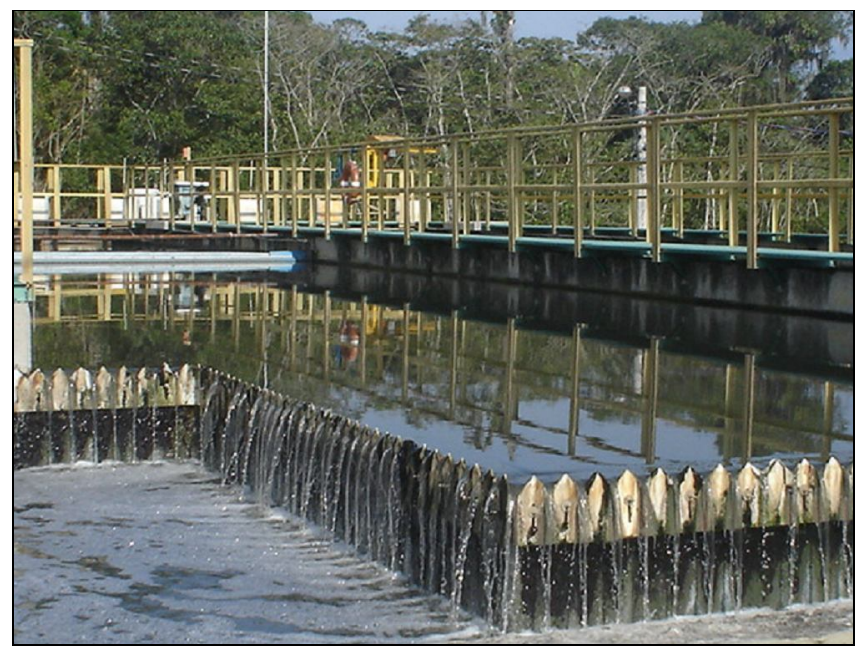

Figura 14: Sedimentadores Primários - TPQA da Estação de Tratamento de Esgoto da Riviera de São Lourenço.

\subsubsection{Elevatória de lodo primário}

Esta unidade permaneceu sem alterações e as bombas diafragma de lodo passaram a ser operadas continuamente ou com intervalos mais curtos para manter baixo $o$ manto de lodo.

Estas bombas enviam o lodo primário para a Lagoa Anaeróbia para digestão anaeróbia.

$\mathrm{Na}$ Figura 15, apresenta-se o barrilete da Elevatória de lodo da Estação de Tratamento de Esgoto da Riviera de São Lourenço. 


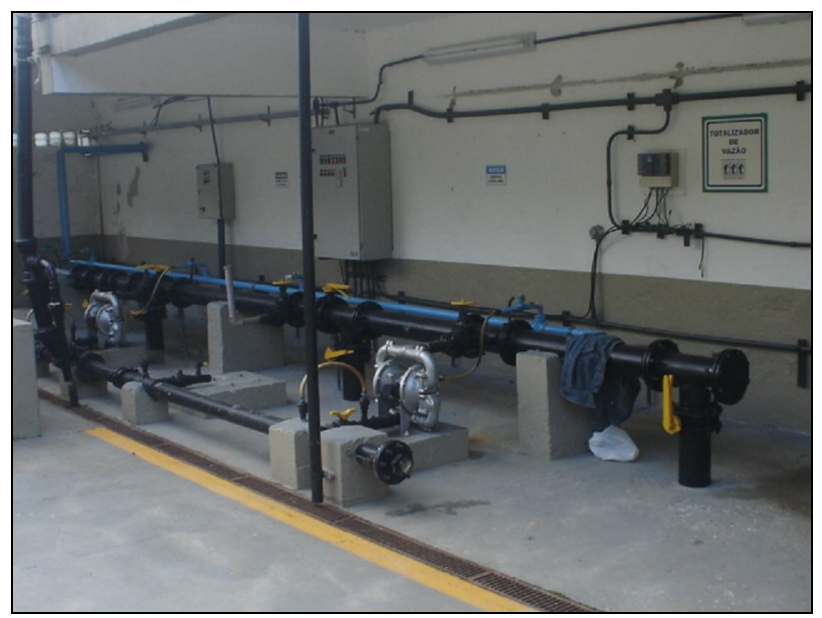

Figura 15: Barrilete da Elevatória de lodo da Estação de Tratamento de Esgoto da Riviera de São Lourenço.

\subsubsection{Lagoas facultativas}

Com as alterações As três lagoas existentes passaram a ser operadas da seguinte forma:

- Duas Lagoas Facultativas LF1 eLF3 em paralelo, recebendo cada uma cerca de metade do fluxo afluente, isto é a soma do efluente do TPQA e da vazão de recirculação oriunda da Lagoa de Maturação (LM);

- Lagoa LM em série com as lagoas LF1e LF3.

Na Figura 16 apresentam-se as Lagoas facultativas e de maturação da Estação de Tratamento de Esgoto da Riviera de São Lourenço. 


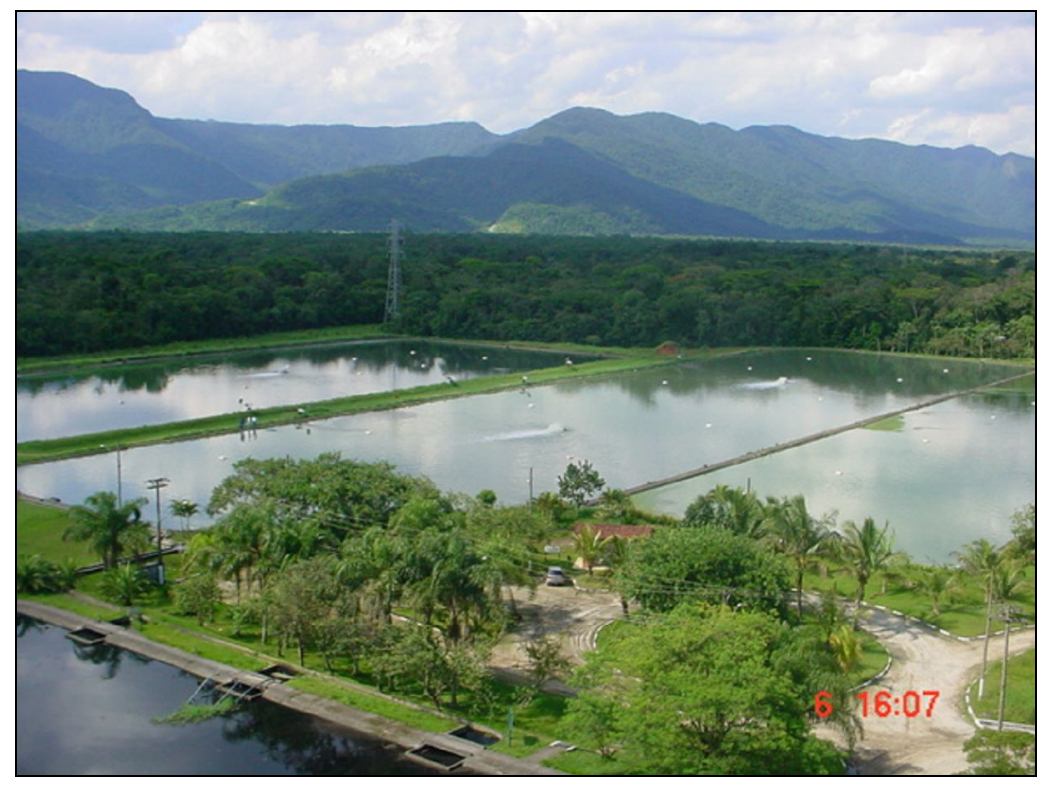

Figura 16: Lagoas facultativas e de maturação da Estação de Tratamento de Esgoto da Riviera de São Lourenço.

\subsubsection{Decantador de algas}

O efluente da LM segue para Decantador de algas implantado no final de 2005. O removedor é constituído das seguintes unidades:

- Canal de mistura rápida;

- Floculadores mecanizados em série;

- Separador de sólidos (módulos tubulares);

- Elevatória de lodo do removedor;

No Decantador de algas são aplicados:

- Solução de polímero catiônico no canal de mistura rápida : dosagem de 1,0 a $2,5 \mathrm{mg} / \mathrm{L}$;

- Leite de cal no canal de mistura rápida : dosagem de de 1:25 em relação ao polímero catiônico;

- Solução de cloro na $2^{\mathrm{a}}$ câmara de floculação: 5 a 10 mg/L. 
Nas Figuras 17 e 18, apresentam-se os floculadores e o removedor de algas e o efluente do Decantador de algas, respectivamente.

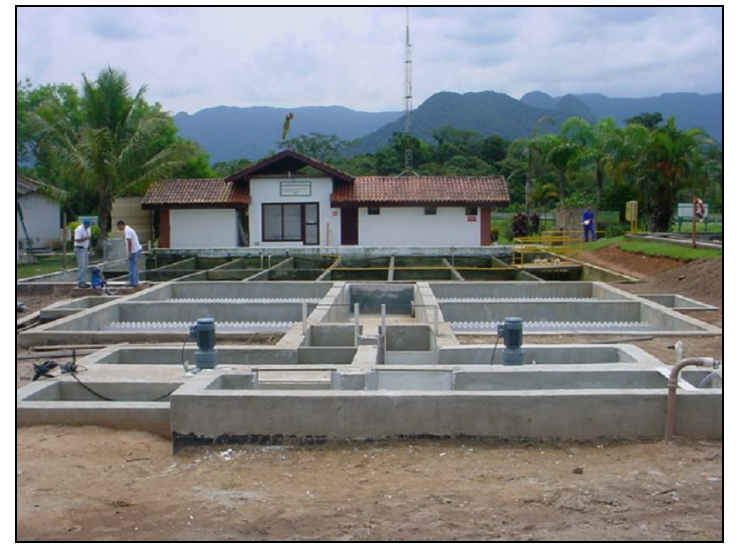

Figura 17: Floculadores e removedor de algas

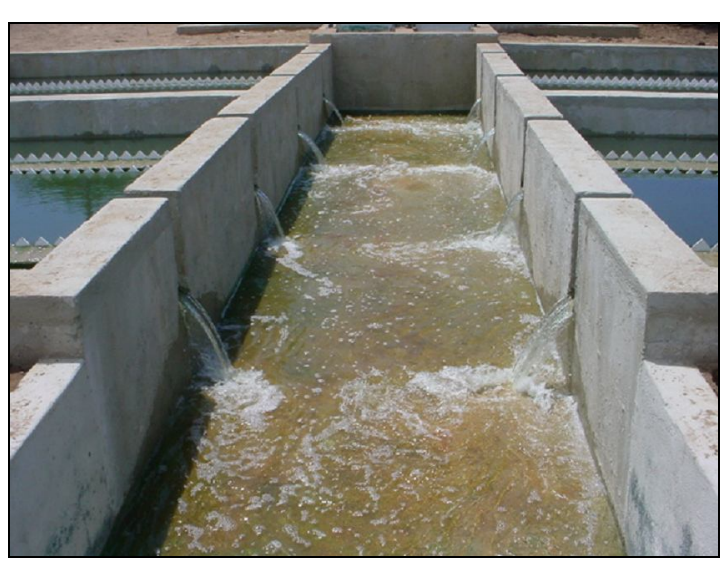

Figura 18: Efluente do Decantador de algas

\subsubsection{Tanque de contato para desinfecção}

Esta unidade permaneceu sem alterações e as características de projeto são:

- Tanque com 8 câmaras em série :

- Volume útil: $400 \mathrm{~m}^{3}$

- Tempo de detenção mínimo: aproximadamente 50min.

$\mathrm{Na}$ Figura 19 apresenta-se o tanque de contato da Estação de Tratamento de Esgoto da Riviera de São Lourenço. 


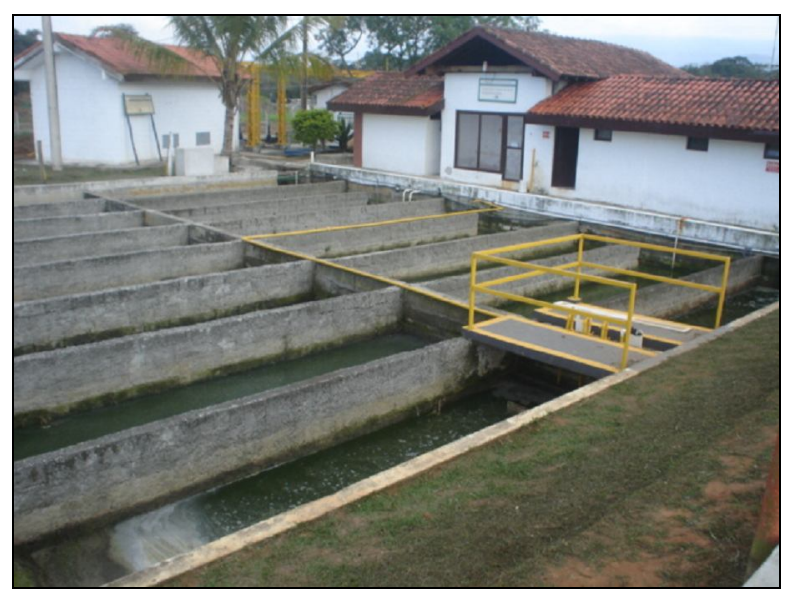

Figura 19: Tanque de contato da Estação de Tratamento de Esgoto da Riviera de São Lourenço.

\subsubsection{Sistema de preparo e dosagem de cal hidratada}

Foi projetado sistema de preparo e dosagem cal a ser empregado no Decantador de algas.

O preparo da suspensão (10 a $40 \mathrm{~g} / \mathrm{L}$ ) é realizado no tanque de cal existente e a dosagem é feita por recalque utilizando bomba de cavidade progressiva de vazão controlável.

Este produto químico será responsável pela precipitação de fósforo e como coagulante primário no processo de remoção de algas.

Nas Figuras 20 e 21 apresentam-se o tanque de Cal Hidratada e o ponto de aplicação no floculador. 


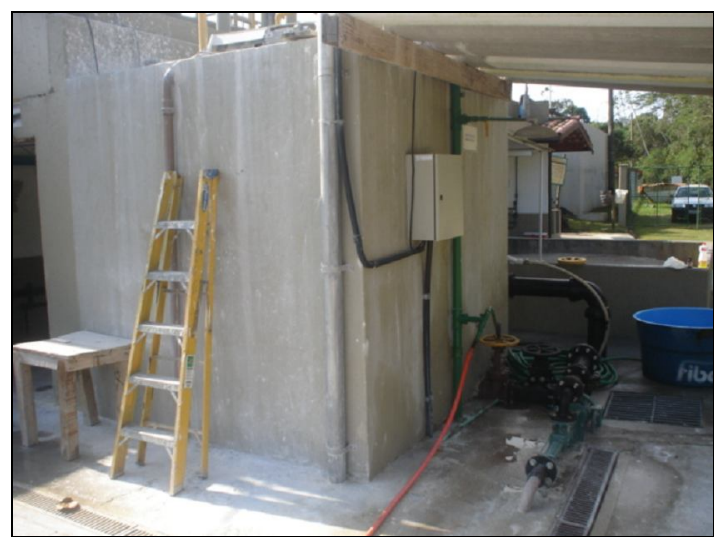

Figura 20: Tanque de Cal Hidratada

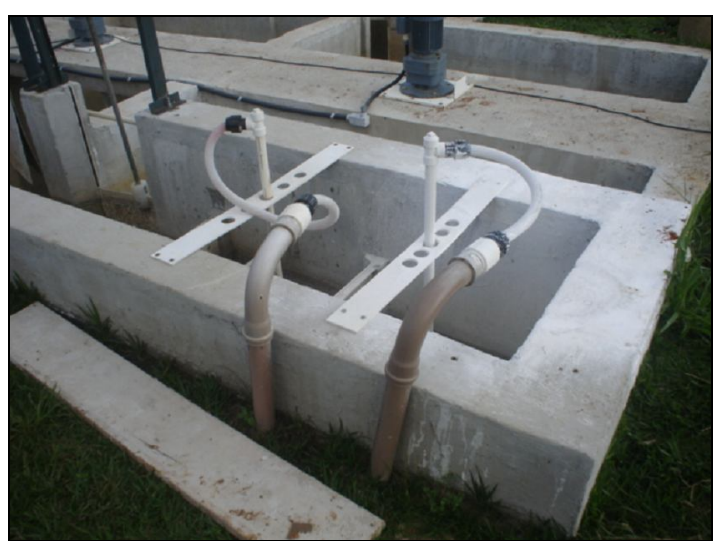

Figura 21: Ponto de aplicação no floculador

\subsubsection{Sistema de preparo e dosagem de polímero}

Foi especificado, adquirido e implantado preparador de solução a partir de polímero em pó.

A solução de polímero varia entre $1,0 \mathrm{mg} / \mathrm{L}$ e $2,5 \mathrm{mg} / \mathrm{L}$ é aplicada nos canais de mistura rápida dos dois sistemas de coagulação/floculação (TPQA e Decantador de algas).

Nas Figuras 22 e 23, apresentam-se o preparador de polímero e o ponto de aplicação no floculador, respectivamente. 


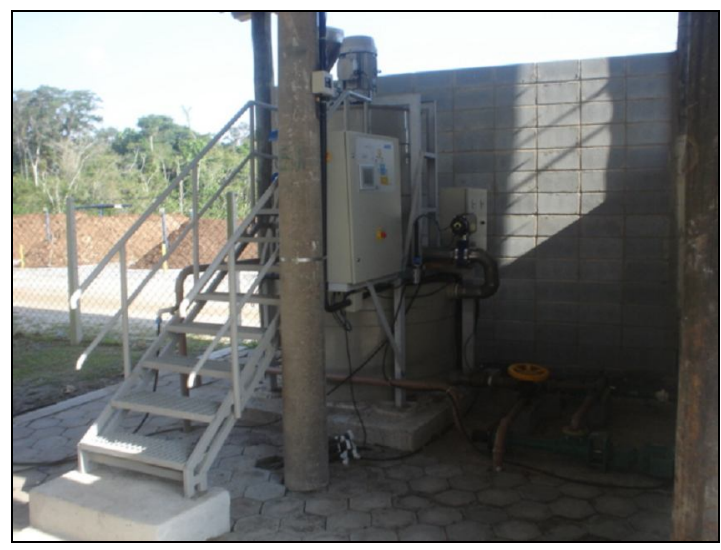

Figura 22: Preparador de Polímero

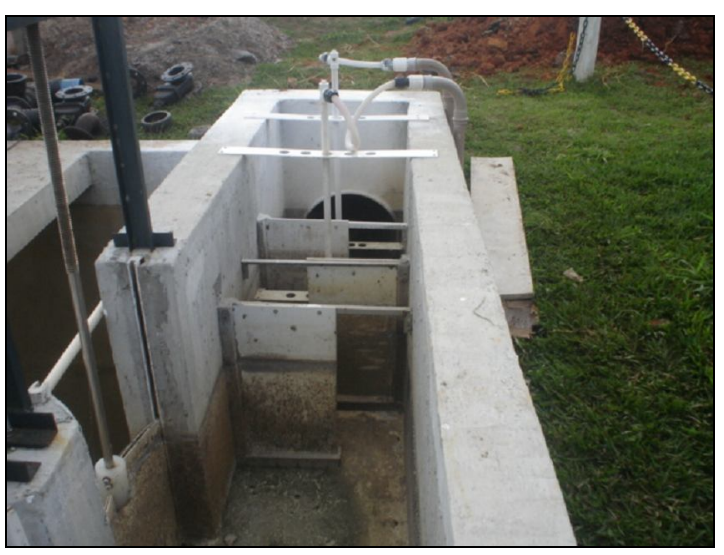

Figura 23: Ponto de aplicação no floculador

\subsubsection{Sistema de cloração}

Foi adquirido e instalado novo clorador e desta forma tornaram-se disponíveis 2 cloradores com capacidade nominal $10 \mathrm{kgCl}_{2} / \mathrm{h}$ a partir de cilindros de cloro gás.

O pontos de aplicação de cloro são:

- O ponto já existente na primeira câmara do tanque de contato;

- Novo ponto de aplicação na $2^{\mathrm{a}}$ câmara de floculação.

$\mathrm{Na}$ Figura 24, apresenta-se o sistema de cloração da Estação de Tratamento de Esgoto.

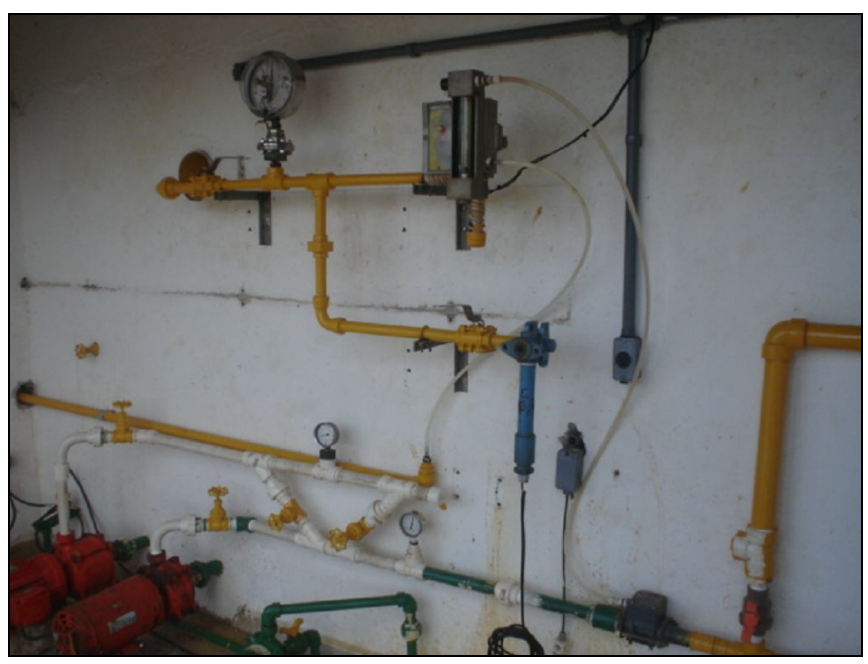

Figura 24: Sistema de cloração da Estação de Tratamento de Esgoto. 
Em resumo, o TPQA durante 11 meses do ano trabalha como um decantador primário sem aplicação de produtos químicos (aplicação de produtos químicos somente na alta temporada - 01 mês - e substituindo o cloreto férrico por polímero catiônico) seguido das lagoas facultativas e lagoa de maturação, utilizando a lagoa anaeróbia existente, porém praticamente vazia, como um tanque pulmão, recebendo o efluente das épocas de pico que excede a vazão de rotina, mantendo assim uma vazão próxima do constante e melhorando a qualidade das LF's, pois, teriam uma população de microorganismos mais estáveis, além de Implantação de um sistema de remoção de algas na saída das lagoas vislumbrando ao atendimento dos parâmetros novos (densidade de cianobactérias e clorofila-a) da CONAMA $357 / 2005$.

$\mathrm{Na}$ Tabela 8 são apresentadas as características das lagoas de Estabilização da Riviera de São Lourenço - Bertioga - SP, são apresentadas abaixo :

Tabela 8: características das lagoas de estabilização da ETE da Riviera de São Lourenço.

\begin{tabular}{lccc}
\hline & LF1 & LF3 & LM \\
\hline Área & $14.920 \mathrm{~m}^{2}$ & $15.484 \mathrm{~m}^{2}$ & $16.328 \mathrm{~m}^{2}$ \\
Profundidade media & $1,47 \mathrm{~m}$ & $1,46 \mathrm{~m}$ & $1,35 \mathrm{~m}$ \\
Volume & $21.932 \mathrm{~m}^{3}$ & $22.606 \mathrm{~m}^{3}$ & $22.042 \mathrm{~m}^{3}$ \\
Altura média de lodo & $11 \mathrm{~cm}$ & $14 \mathrm{~cm}^{2}$ & $20 \mathrm{~cm}^{2}$ \\
Volume de lodo & $1.739 \mathrm{~m}^{3}$ & $2.292 \mathrm{~m}^{3}$ & $3.327 \mathrm{~m}^{3}$ \\
& & & \\
\hline \multicolumn{2}{c}{ Obs.: dados resultados de estudo de batimetria em maio de 2005.}
\end{tabular}

Nas Figuras 25, 26, são apresentadas algumas plantas das unidades do sistema de Tratamento de Esgotos da Riviera de São Lourenço, para melhor visualização do sistema. 


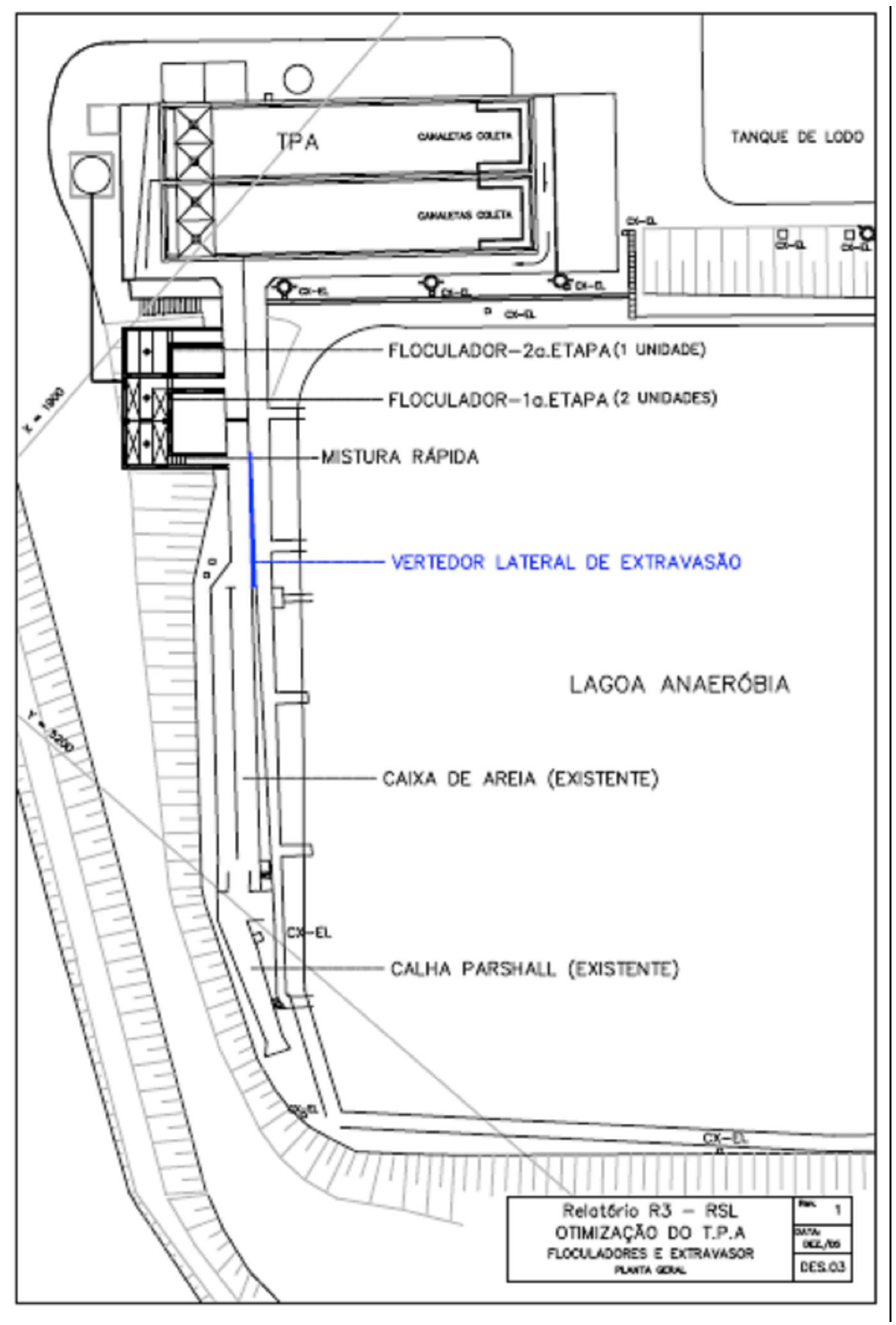

Figura 25: planta baixa geral da entrada do sistema até o TPQA. 


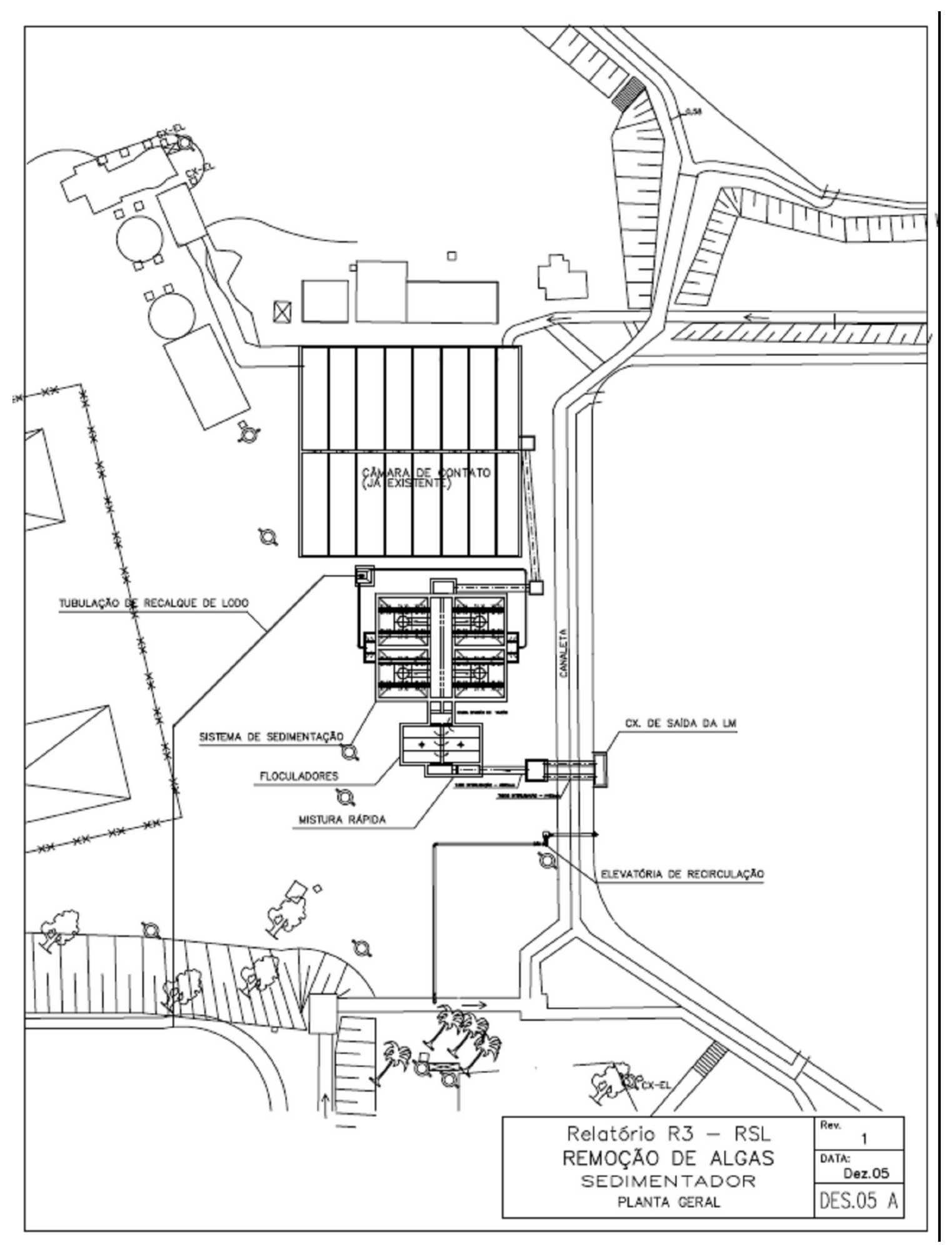

Figura 26: Planta geral baixa do floculador, sedimentador e caixa de contato. 


\subsection{Características do Esgoto da Riviera}

Como se pode observar nas Figuras 27 e 28, os volumes afluentes ao sistema de esgotos da Riviera possuem uma sazonalidade que varia com os períodos de alta temporada (janeiro e fevereiro) e baixa temporada (outros meses do ano) de ocupação. Sendo que os valores de DBO também acabam por ter características de esgoto fraco para médio.

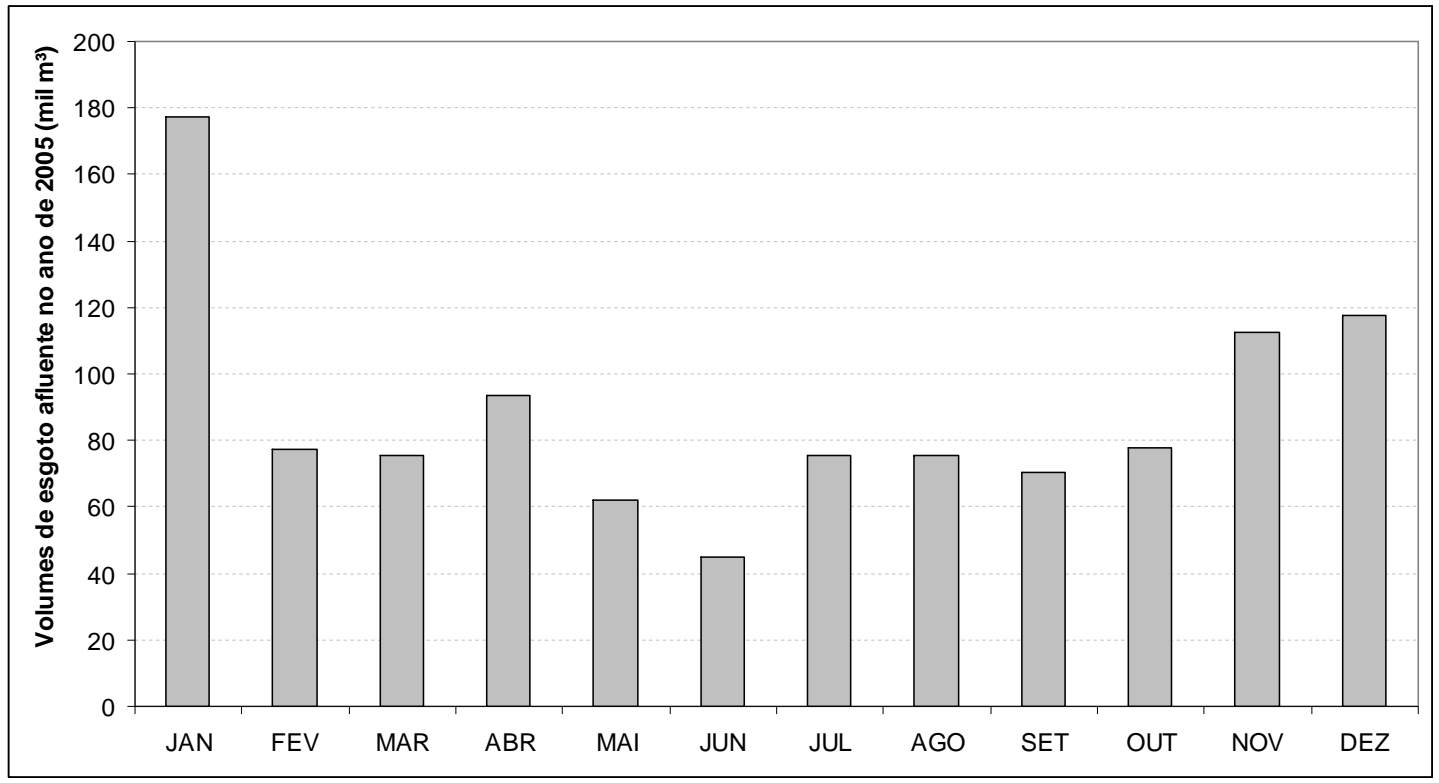

Figura 27: Volume de esgoto afluentes ao sistema de tratamento de esgoto da Riviera em 2005.

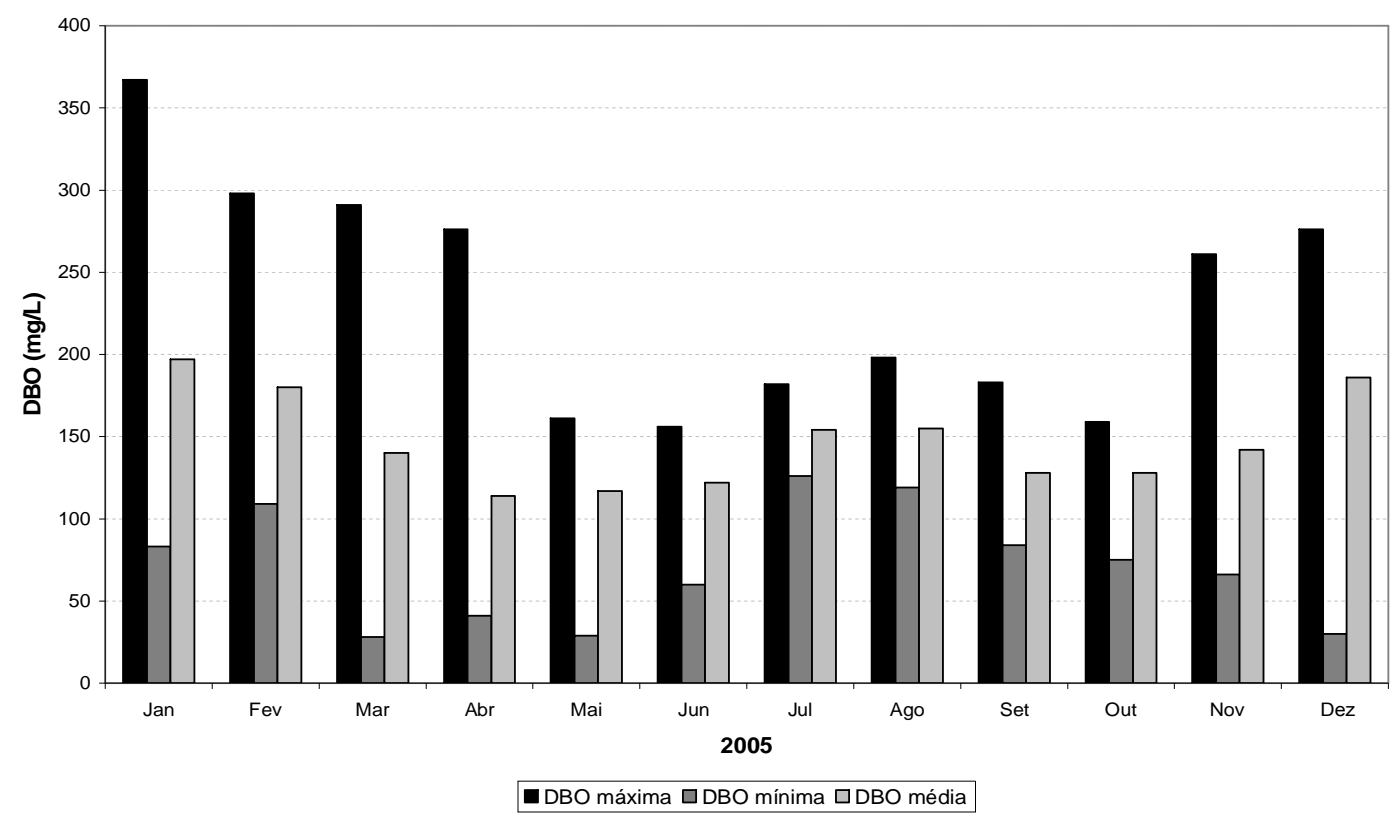

Figura 28: Valores de DBO afluentes ao sistema de tratamento de esgoto da Riviera no ano de 2005. 


\subsection{Programa de coleta e análises de amostras}

As amostragens e análises foram conduzidas seguindo o programa estabelecido, variando de semanal e quinzenal para os parâmetros específicos e de suporte.

\subsubsection{Pontos de Amostragem}

\subsubsection{Saída das Lagoas Facultativas}

Nas Figuras 29 e 30, apresentam-se a coleta na saída das LF's e a Transferência da amostra, respectivamente.

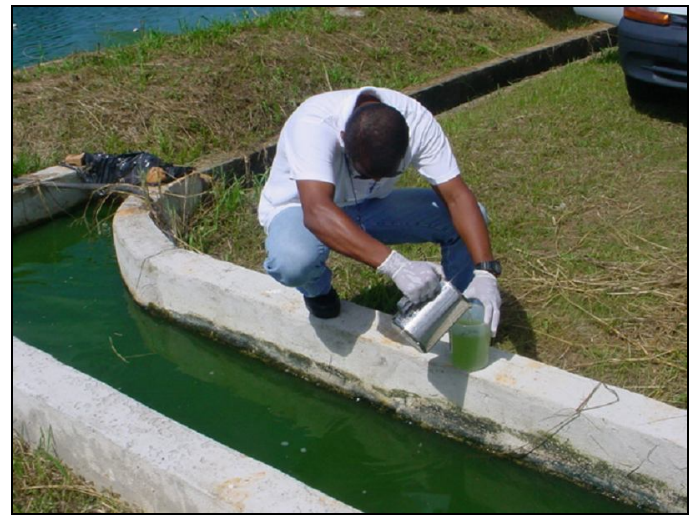

Figura 29: Coleta na saída das LF's

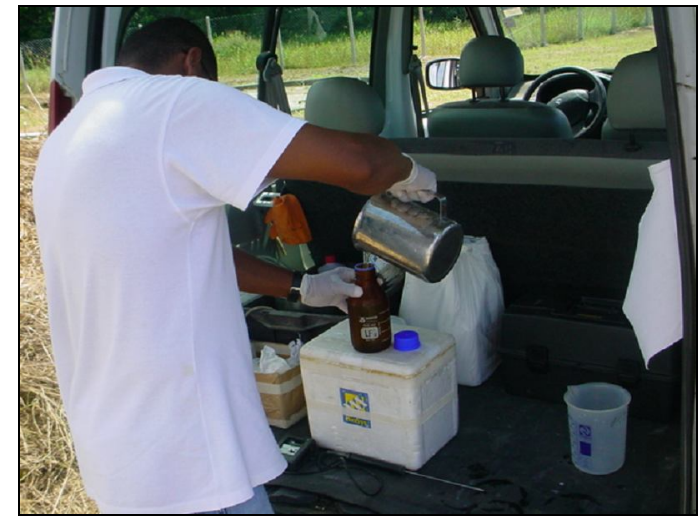

Figura 30: Transferência da amostra

\subsubsection{Saída da Lagoa de Maturação}

Na Figura 31, apresenta-se o ponto de coleta na saída da Lagoa de Maturação.

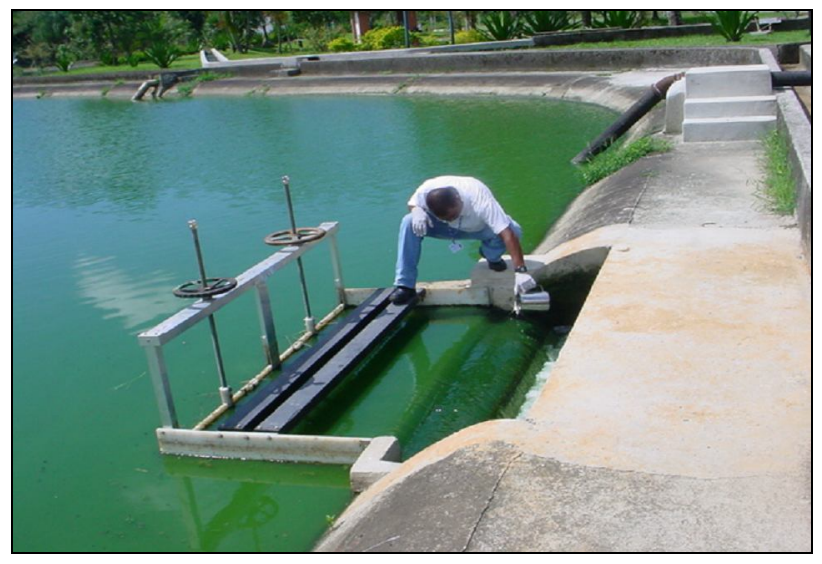

Figura 31: Coleta na saída da Lagoa de Maturação. 


\subsubsection{Saída do tanque de remoção de algas}

$\mathrm{Na}$ Figura 32 e 33, apresentam-se o ponto de coleta na saída do RA e uma transferência da amostra, respectivamente.

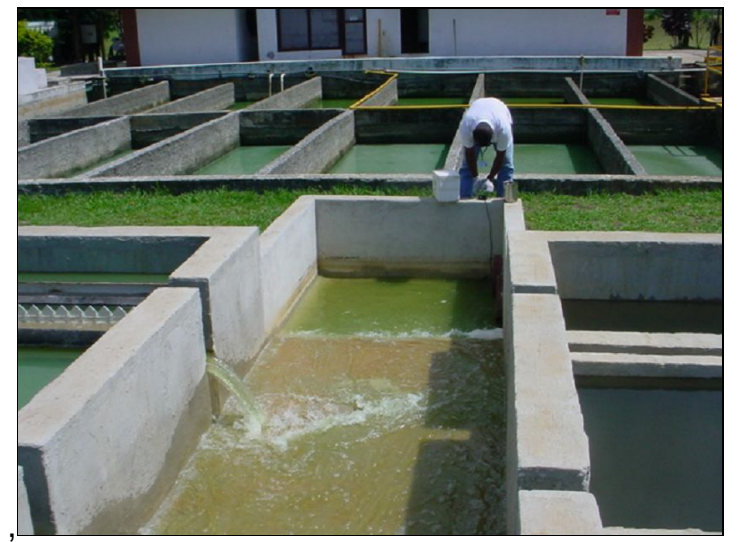

Figura 32: Coleta na saída do RA

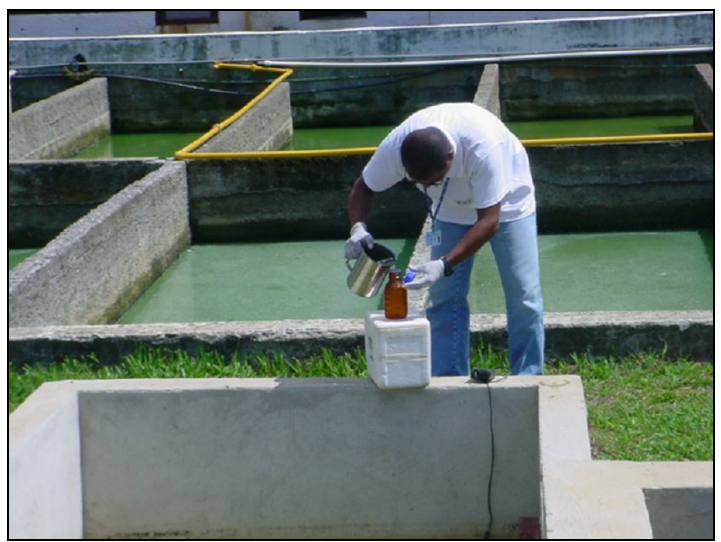

Figura 33: Transferência da amostra

\subsubsection{Saída do tanque de contato de cloro}

Nas Figuras 34 e 35, apresentam-se o ponto de coleta na saída da caixa de contato e uma transferência da amostra para o frasco, respectivamente.

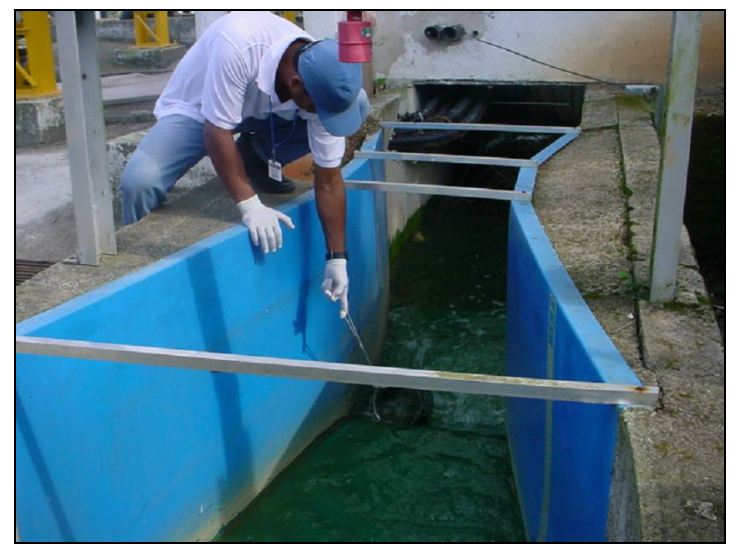

Figura 34: Coleta na saída da caixa de contato

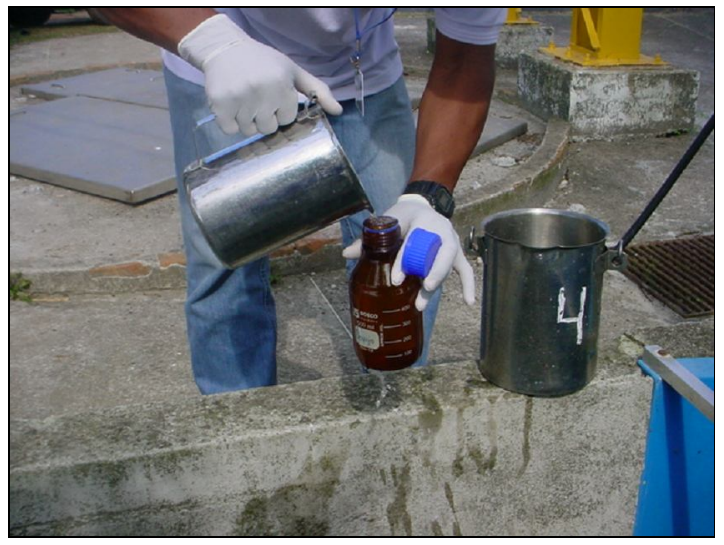

Figura 35: Transferência da amostra para o frasco 


\subsection{Parâmetros analisados e freqüência de análises}

\subsubsection{Variáveis de controle}

A Tabela 9 apresenta a freqüência de análises das variáveis de controle ao longo do período estudado.

Tabela 9: freqüência de análise das variáveis de controle

\begin{tabular}{cc}
\hline PARÁMETRO & FREQUÉNCIA \\
\hline Cianobactérias & quinzenal \\
Clorofila-a & semanal \\
\hline
\end{tabular}

Para a determinação de cianobactéria, adotou-se como ponto afluente a saída das lagoas facultativas e efluente a saída do sistema.

Para a determinação de clorofila-a, adotou-se como ponto afluente a saída da lagoa de maturação e efluente a saída do sistema.

\subsubsection{Variáveis de suporte}

A Tabela 10 apresenta a freqüência de análises das variáveis de suporte ao longo do período estudado. 
Tabela 10: freqüência de análise das variáveis de suporte

\begin{tabular}{cc}
\hline PARÁMETRO & FREQUÉNCIA \\
\hline DQO & Semanal \\
DBO & Semanal \\
$\mathrm{pH}$ & Semanal \\
SST & Semanal \\
Fósforo & Semanal \\
Nitrogênio amoniacal & Semanal \\
\hline
\end{tabular}

Para todas as variáveis de suporte adotou-se como ponto afluente à entrada do sistema.

\subsubsection{Duração}

Os experimentos foram desenvolvidos entre outubro de 2005 e Junho de 2006. Os períodos de outubro a dezembro de 2005 e de março a junho de 2006 foram considerados como de baixa temporada, enquanto que os meses de janeiro e fevereiro de 2006 foram considerados de alta temporada.

\subsubsection{Período de análises}

O controle laboratorial sobre o sistema de tratamento foi exercido da seguinte forma:

- Outubro/2005 a Junho/2006 - Efluente das Lagoas facultativas

- Outubro/2005 a Junho/2006 - Efluente da Lagoa de Maturação

- Outubro/2005 a Junho/2006 - Efluente da chicana de cloração

- Dezembro/2005 a Junho/2006 - Efluente do Tanque de remoção de algas. 


\subsection{Métodos Analíticos}

A metodologia para análise de todos os parâmetros que foram utilizados neste trabalho seguiram as normas da CETESB e Standard Methods.

\subsubsection{Parâmetros de suporte}

Os métodos de análise dos parâmetros de suporte podem ser observados na Tabela 11.

Tabela 11: métodos de determinação dos parâmetros de suporte

\begin{tabular}{|c|c|}
\hline PARÂMETRO & METODO \\
\hline DQO & Norma CETESB L5.721 \\
\hline DBO & Norma CETESB L5.120 \\
\hline $\mathrm{pH}$ & $\begin{array}{c}\text { Norma CETESB L5.145: Água - Determinação de pH em águas. } \\
\text { Método Eletrométrico }\end{array}$ \\
\hline SST & Norma CETESB L5.149: Água - Determinação de Sólidos em Águas \\
\hline Fósforo & $\begin{array}{l}\text { Método 10013: Manual de Procedimentos para Espectrofotômetro } \\
\text { DR/2000-HACH } \\
\text { Método Teste no Tubo Digestão Ácida de Persulfato e PhosVer } 3\end{array}$ \\
\hline \multirow[t]{2}{*}{ Nitrogênio } & Método 10031: Manual de Procedimentos para Colorímetro \\
\hline & DR/890-HACH \\
\hline amoniacal & Método de Salicilato \\
\hline
\end{tabular}




\subsubsection{Parâmetros de controle}

\subsubsection{Determinação para densidade de cianobactérias}

\subsection{Metodologia utilizada}

Utilizou-se as normas CETESB L5.313 - Coleta de Fitoplâncton Marinho e de água doce: Procedimento e L5.303 - Determinação de Fitoplâncton de água doce Métodos qualitativo e quantitativo: método de ensaio.

\subsection{Aplicabilidade}

O exame da comunidade fitoplanctônica, dependendo do objetivo do estudo, pode ser realizado através do levantamento qualitativo ou quantitativo das espécies existentes em um determinado volume de amostra, podendo ainda envolver uma estimativa da biomassa dos componentes dessa comunidade. Através do conhecimento das espécies existente no meio, da biomassa, do significado sanitário dos gêneros e espécies mais freqüentes na amostra, da aplicação de índice e de correlações com dados físico-químicos, pode-se caracterizar o tipo e a qualidade do ambiente em estudo, principalmente quanto ao grau de eutrofização.

\subsection{Interferências}

São consideradas interferências:

- Diluição da amostra com a substancias utilizadas na preservação dos organismos;

- evaporação da amostra. 


\subsection{Aparelhos para amostragem}

Foram utilizados os seguintes equipamentos de amostragem:

- garrafa de coleta

- rede de plâncton

- baldes

- frascos de vidro neutro (âmbar ou transparente) de boca larga, com um litro de capacidade

- frasco de vidro neutro (âmbar ou transparente) de boca larga com $125 \mathrm{~mL}$ de capacidade

- pipetas graduadas

- pissetes

- funil

- caixa de isopor

\subsection{Preservantes e reagentes}

Foram utilizados os seguintes reagentes:

- formol comercial 40\%, neutralizado com bicarbonato de sódio,

- solução de lugol

- solução de mertiolato

- solução de transeau

- detergente

- azul de metileno

- tinta nanquim

- solução de rosa de bengala, usa-se $15 \mathrm{~mL}$ por litro para o preparo dessa solução, dissolve-se $1 \mathrm{~g}$ de rosa de bengala em $100 \mathrm{~mL}$ de água destilada

- solução saturada de sulfato de cobre 


\subsection{Aparelhos para execução de ensaios}

Foram utilizados os seguintes equipamentos de laboratório:

- centrifuga

- balança

- pipetas graduadas

- provetas

\subsection{Aparelho para execução de exames microscópicos}

Foram utilizados os seguintes equipamentos nos exames microscópicos:

- microscópio binocular comum, equipado com ocular de 10X e objetiva de 20X câmaras de S-R (Sedgwick-Rafter), essas câmaras apresentam 20mm de largura, $50 \mathrm{~mm}$ de comprimento, $1 \mathrm{~mm}$ de altura e capacidade de $1 \mathrm{~mL}$.

- pipetas graduadas

- micrometro

- laminas e lamínulas comuns

- reticulo de Whipple

- contador manual de varias teclas

- câmara úmida 


\subsection{Cálculos do fator de contagem por campos}

Na Figura 36 apresenta-se a seqüência explicativa para contagem dos campos.

\begin{tabular}{|c|c|}
\hline Retículo Milimetrado & Câmara de Sedgwick - Rafter \\
\hline 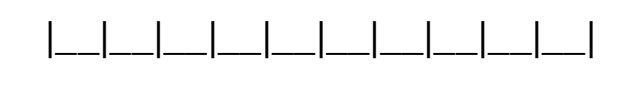 & \\
\hline $\begin{array}{llllll}0 & 0,1 & 0,2 & 0,3 & 0,4 & 0,5\end{array}$ & Área $=20 \times 50=1000 \mathrm{~mm}^{2}$ \\
\hline $\begin{array}{lllll}0,6 & 0,7 & 0,8 & 0,9 & 1,0 \mathrm{~mm}\end{array}$ & Volume $=1000 \mathrm{~mm}^{3}=1 \mathrm{~mL}$ \\
\hline Cada $0,1 \mathrm{~mm}$ é subdividido em 0,01 & 1Campo \\
\hline mm (cada 1,0 mm contém 100 & \\
\hline divisões) & \\
\hline
\end{tabular}

Figura 36: seqüência explicativa para contagem dos campos.

\subsection{Cálculos da Área ( $L \times L=a)$}

Na Tabela 12 apresentam-se os procedimentos de cálculo da área do campo da lâmina para análise de cianobactérias.

Tabela 12: cálculo da área do campo da lâmina para análise de cianobactérias.

\begin{tabular}{ccc}
\hline Objetiva & $\begin{array}{c}\text { Lado } \times \text { Lado } \\
(\mathbf{m m})\end{array}$ & $\begin{array}{c}\text { Área do Campo (a) } \\
\mathbf{m m}^{\mathbf{2}}\end{array}$ \\
\hline $\mathbf{4 x}=$ & $0,4 \times 0,4=$ & $\mathbf{0 , 1 6}$ \\
$\mathbf{1 0}=$ & $1,0 \times 1,0=$ & $\mathbf{1 , 0}$ \\
$\mathbf{2 0}=$ & $2,0 \times 2,0=$ & $\mathbf{4 , 0}$ \\
$\mathbf{4 0}=$ & $4,0 \times 4,0=$ & $\mathbf{1 6 , 0}$ \\
\hline
\end{tabular}




\subsection{Cálculo do Fator}

$F=\frac{A}{a}$

onde:

$\mathrm{F}=$ Fator de Contagem

$A$ = área da câmara

$\mathrm{a}=$ área do campo

Exemplo:

Ocular de 10x

Objetiva de $40 \mathrm{x}$

$$
\begin{array}{cc}
\mathrm{F}_{1 \text { campo }}=\underline{1000}= & \mathrm{F}_{3 \text { campos }}=\frac{1000}{62,50}= \\
16 & 20,83 \\
16 \cdot 3
\end{array}
$$

№ de Células $\times$ Fator de Conversão $=$ № de Células $/ \mathrm{mL}$ 
Na Tabela 13 apresenta-se a conversão para fator de contagem de cianobactérias.

Tabela 13: Conversão para fator de contagem de cianobactérias.

TABELA DE CONVERSÃO - FATOR DE CONTAGEM

- Objetiva $10 \mathrm{x}-$

\begin{tabular}{cccccc}
\hline & \multicolumn{3}{c}{ Aumento 4 x } & \multicolumn{3}{c}{ Aumento 10 x } \\
CAMPOS & $\begin{array}{c}\text { Área } \\
\left(\mathrm{mm}^{2}\right)\end{array}$ & $\begin{array}{c}\text { Fator de } \\
\text { Conversão }\end{array}$ & CAMPOS & $\begin{array}{c}\text { Área } \\
\left(\mathrm{mm}^{2}\right)\end{array}$ & $\begin{array}{c}\text { Fator de } \\
\text { Conversão }\end{array}$ \\
1 & 0,16 & 6250,00 & 1 & 1 & 1000,00 \\
2 & 0,32 & 3125,00 & 2 & 2 & 500,00 \\
3 & 0,48 & 2083,33 & 3 & 3 & 333,33 \\
4 & 0,64 & 1562,50 & 4 & 4 & 250,00 \\
5 & 0,8 & 1250,00 & 5 & 5 & 200,00 \\
6 & 0,96 & 1041,67 & 6 & 6 & 166,67 \\
7 & 1,12 & 892,86 & 7 & 7 & 142,86 \\
8 & 1,28 & 781,25 & 8 & 8 & 125,00 \\
9 & 1,44 & 694,44 & 9 & 9 & 111,11 \\
10 & 1,6 & 625,00 & 10 & 10 & 100,00
\end{tabular}

\begin{tabular}{|c|c|c|c|c|c|}
\hline \multicolumn{3}{|c|}{ Aumento $20 \mathrm{x}$} & \multicolumn{3}{|c|}{ Aumento $40 \mathrm{x}$} \\
\hline CAMPOS & $\begin{array}{l}\text { Área } \\
\left(\mathrm{mm}^{2}\right)\end{array}$ & $\begin{array}{l}\text { Fator de } \\
\text { Conversão }\end{array}$ & CAMPOS & $\begin{array}{l}\text { Área } \\
\left(\mathrm{mm}^{2}\right)\end{array}$ & $\begin{array}{c}\text { Fator de } \\
\text { Conversão }\end{array}$ \\
\hline 1 & 4 & 250,00 & 1 & 16 & 62,50 \\
\hline 2 & 8 & 125,00 & 2 & 32 & 31,25 \\
\hline 3 & 12 & 83,33 & 3 & 48 & 20,83 \\
\hline 4 & 16 & 62,50 & 4 & 64 & 15,63 \\
\hline 5 & 20 & 50,00 & 5 & 80 & 12,50 \\
\hline 6 & 24 & 41,67 & 6 & 96 & 10,42 \\
\hline 7 & 28 & 35,71 & 7 & 112 & 8,93 \\
\hline 8 & 32 & 31,25 & 8 & 128 & 7,81 \\
\hline 9 & 36 & 27,78 & 9 & 144 & 6,94 \\
\hline 10 & 40 & 25,00 & 10 & 160 & 6,25 \\
\hline
\end{tabular}


Nas Figuras 37 à 44, apresentam-se os procedimentos para transferência, homogeneização, preservação e contagem de cianobactérias.

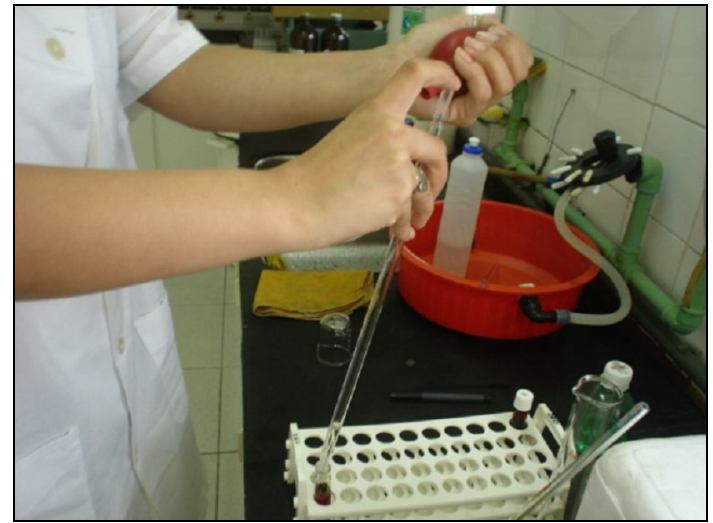

Figura 37: Transferência da amostra para o tubo de lugol

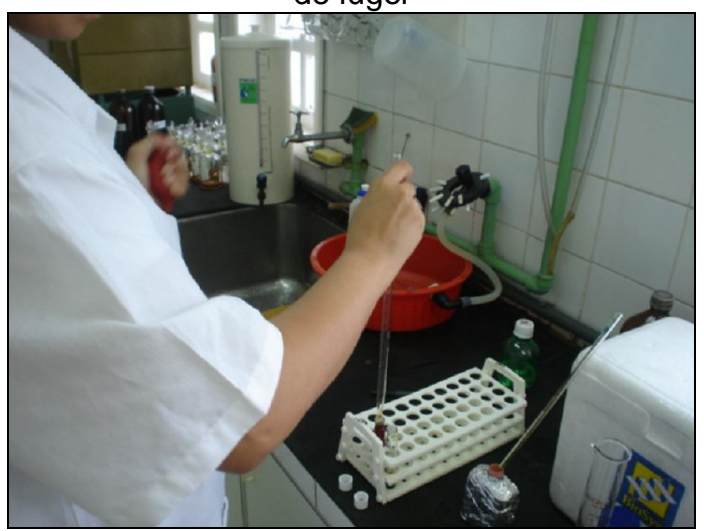

Figura 39: Preservação da amostra com lugol

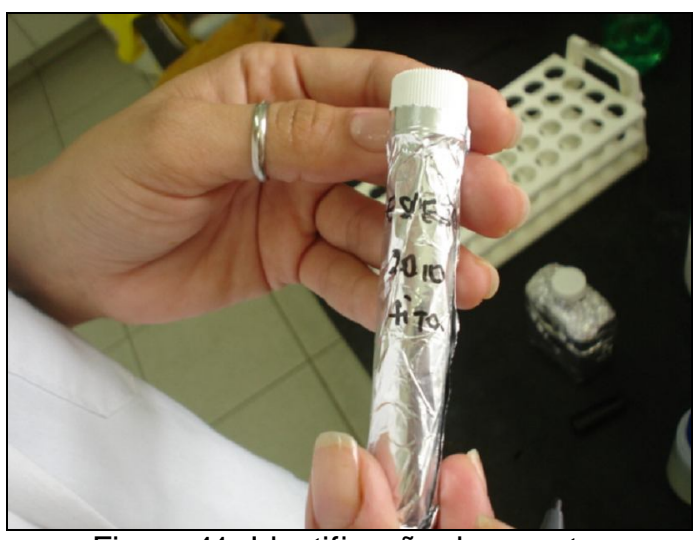

Figura 41: Identificação da amostra

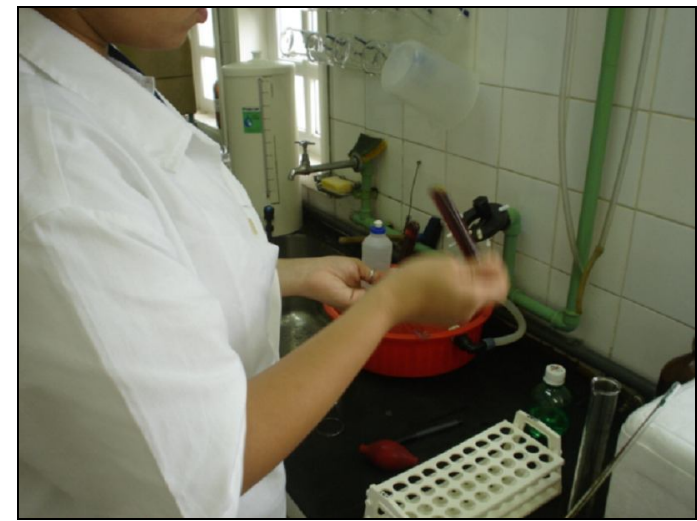

Figura 38: Homogeneização da amostra com lugol

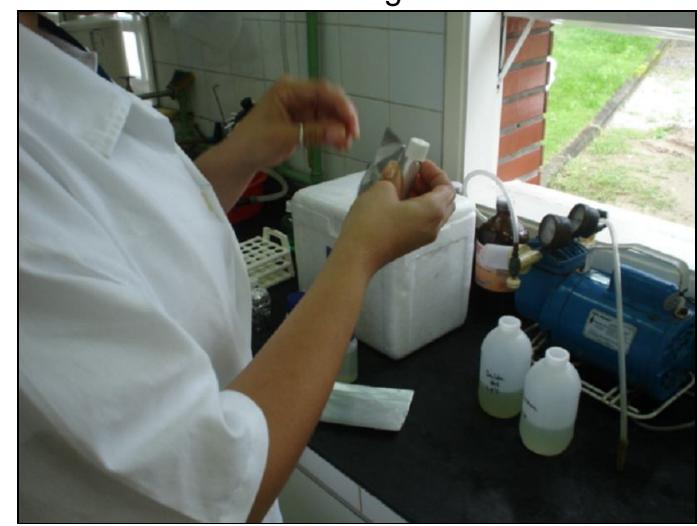

Figura 40: envolvimento do tubo para manter a amostra no escuro

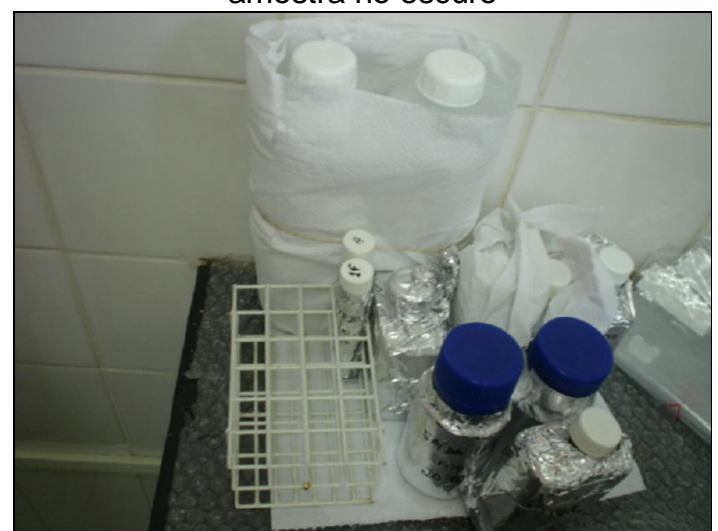

Figura 42: Preservação da amostra com lugol em cubetas e frascos de formol. 


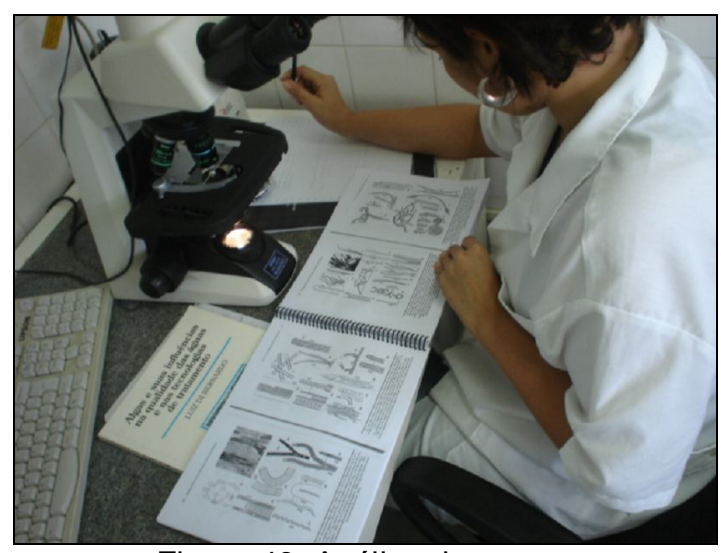

Figura 43: Análise da amostra

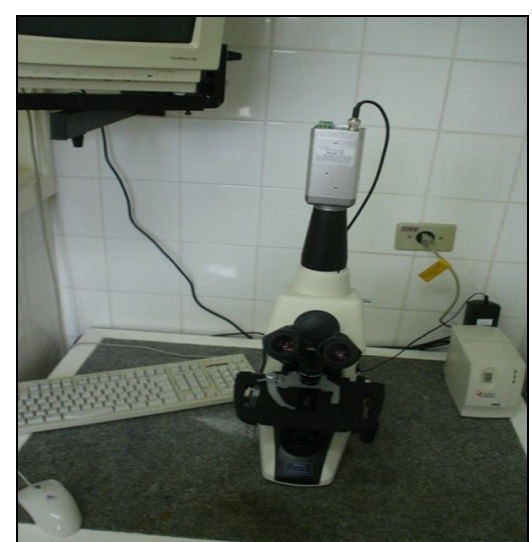

Figura 44: Microscópio utilizado - Nikon Eclipse E200

\subsubsection{Determinação de clorofila-a}

Há vários tipos de clorofilas, mas a mais importante é a clorofila-a que torna possível a fotossíntese, e todas as algas e plantas possuem clorofila-a. A clorofila-b ocorre somente no grupo nas clorofíceas ou algas verdes e nas demais plantas superiores, e a clorofila-c ocorre no grupo dos dinoflagelados.

Pigmentos são compostos químicos que refletem e absorvem comprimentos de onda específicos da luz visível, o que confere coloração ao organismo. As algas possuem alguns tipos de pigmentos principais que diferem por sua composição química e são as clorofilas, carotenóides (carotenos e xantofilas) e focolilíninas (ficocianinas e ficoeritrinas) (Lívia Agujaro - CETESB, 2005).

A concentração de pigmentos fotossintéticos é usada extensivamente para estimar a biomassa do fitoplâncton.

Todas as plantas verdes possuem clorofila-a, o que constitui aproximadamente 1-2\% do peso seco das algas planctônicas. Outros pigmentos que ocorrem no fitoplâncton incluem clorofilas b e c, xantofilas, ficobilinas e carotenos. Os produtos da degradação da clorofila mais importantes encontrados no meio aquáticos são os colorofilídeos, feoforbideos e feofitinas. 
Três métodos diferentes podem ser empregados na determinação da clorofila-a no fitoplâncton: métodos espectrofotométricos, fluorométricos e técnicas em cromatografia líquida de alta eficiência (HPLC). Ambas as técnicas são utilizadas para a determinação da clorofila após a sua devida extração utilizando solventes orgânicos, como álcool ou acetona.

\subsection{Metodologia utilizada}

Utilizou-se a Norma CETESB L5.306: Determinação de Pigmentos Fotossintetizantes Clorofila-a, B, e C e Feotinina-A.

\subsection{Princípio do método}

As concentrações de clorofila-a, b e c e feofitina-a são determinadas espectrofotometricamente, através das leituras das densidades ópticas em três comprimentos de onda definidos.

O método fornece resultado em termos de peso dos referidos pigmentos por unidade de volume.

\subsection{Amostragem}

A amostragem foi efetuada segundo as especificações apresentadas no Guia de Coleta e Preservação de Amostra de Água da CETESB. 


\subsubsection{Procedimento de extração}

Concentrou-se a amostra por filtração tão logo quanto possível após a coleta. Utilizou-se entre 100 e $300 \mathrm{~mL}$ de amostra. Mantiveram-se as amostras refrigeradas a $4^{\circ} \mathrm{C}$ em frascos escuros ou opacos. Utilizaram-se materiais limpos e sem resíduos ácidos.

Após a concentração da amostra no filtro, enrolou-se o mesmo com o auxilio de baqueta e pinça.

Introduziu-se o filtro enrolado dentro de um tubo de ensaio com tampa de rosca e adicionaram-se $10 \mathrm{~mL}$ de solução de acetona $90 \%$.

Envolveu-se o tubo com papel alumínio e manter a amostra em solução por pelo menos 2 horas a $4^{\circ} \mathrm{C}$ no escuro.

Após o período de refrigeração transferiu-se a amostra em solução para outro tubo de ensaio (envolvido com papel alumínio) e desprezou-se o filtro.

Procedeu-se à determinação espectrofotométrica.

\subsubsection{Determinação espectrofotométrica}

A clorofila-a pode ser superestimada devido a feopigmentos que absorvem próximo ao comprimento de onda de absorção da clorofila-a. Adição de ácido à clorofila a resulta na perda do átomo de magnésio, convertendo-a em feofitina-a Quando uma solução de clorofila-a pura é convertida em feofitina-a por acidificação, a razão de pico de absorção (OD664/OD665) de 1,70 é usada na correção da concentração aparente de clorofila para feofitina-a. 
Utilizando uma cubeta de $1 \mathrm{~cm}$ leu-se a densidade ótica a 750 e $664 \mathrm{~nm}$. Acidificouse o extrato na cubeta com $0,1 \mathrm{~mL}$ de $\mathrm{HCl} 0,1 \mathrm{~N}$. Agitou-se gentilmente o extrato e leu-se a densidade óptica a 750 e 665 nm, 90 s após a acidificação.

A densidade ótica em 664nm antes da acidificação deve estar entre 0,1 e 1,0. Corrigiu-se a densidade ótica obtida com cubetas maiores antes dos cálculos. Subtraiu-se a densidade ótica a 750nm das leituras antes $(664 \mathrm{~nm})$ e depois da acidificação (665 nm). Usando os valores corretos calcule a clorofila-a e feofitina-a por metro cúbico de acordo com a equação (1):

$$
\begin{aligned}
& \text { Clorofila-a }\left(\mathrm{mg} / \mathrm{m}^{3}\right)=\underline{26,7}\left(664_{\underline{b}}-665_{2}\right) \times \mathrm{V}_{1} \\
& \mathrm{~V}_{2} \times \mathrm{L} \\
& \text { Feofitina- } a\left(\mathrm{mg} / \mathrm{m}^{3}\right)=\underline{26,7}\left[1,7\left(665_{a}-664_{b}\right] \times \mathrm{V}_{1}\right. \\
& \mathrm{V}_{2} \times \mathrm{L}
\end{aligned}
$$

Onde:

$\mathrm{V}_{1}=$ volume do extrato, $\mathrm{L}$

$V_{2}=$ volume da amostra, $\mathrm{m}^{3}$

$\mathrm{L}=$ comprimento do caminho ótico ou largura da cubeta, $\mathrm{cm}$

$664_{b}, 665_{a}=$ densidades óticas do extrato em acetona $90 \%$ antes e depois da acidificação, respectivamente.

O valor 26,7 é uma correção na absorção e corresponde a $\mathrm{A} \times \mathrm{K}$, onde:

$A=$ coeficiente de absorbância para clorofila a $664 \mathrm{~nm}=11,0$

$\mathrm{K}=$ razão que expressa a correção para acidificação

$$
\mathrm{K}=\frac{\left(664_{\mathrm{b}} / 664_{\mathrm{a}}\right) \text { clorofila a pura }}{\left(664_{\mathrm{b}} / 664_{\mathrm{a}}\right) \text { clorofila a pura }-\left(664_{\mathrm{b}} / 664_{\mathrm{a}}\right) \text { feofitina-a pura }}=\frac{1,7}{1,7-1,0}=2,43
$$


Nas Figuras 45 a 54, apresentam-se as seqüências de preparação, extração e análise de clorofila-a.

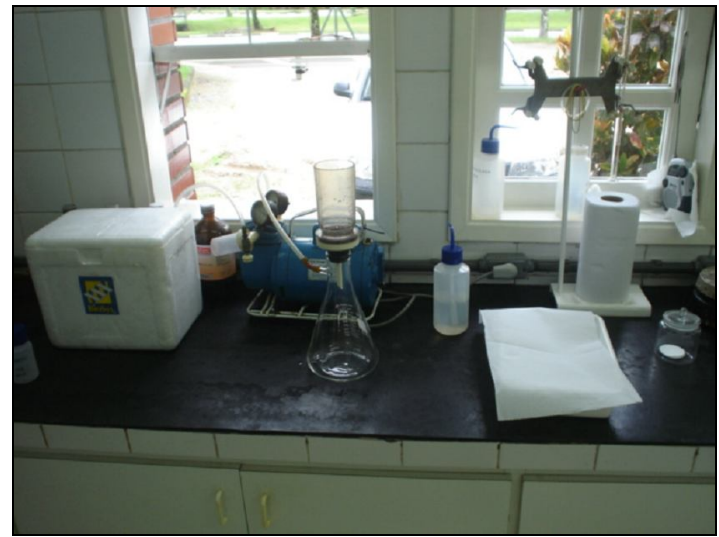

Figura 45: Preparação da amostra

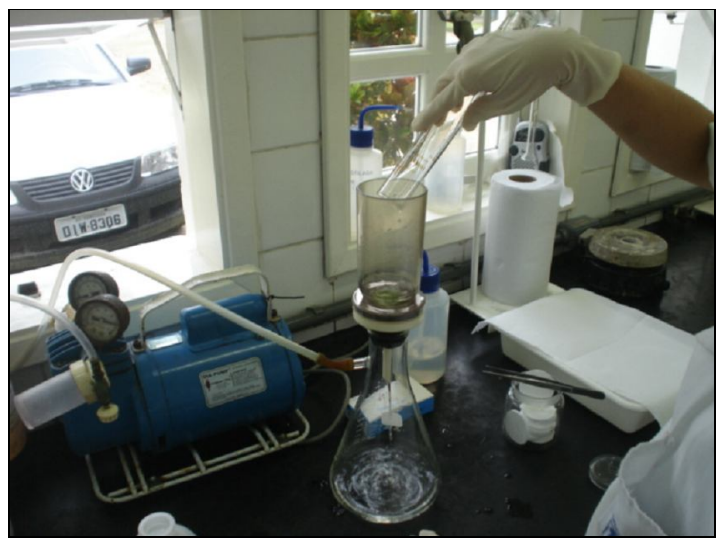

Figura 47: Filtração da amostra

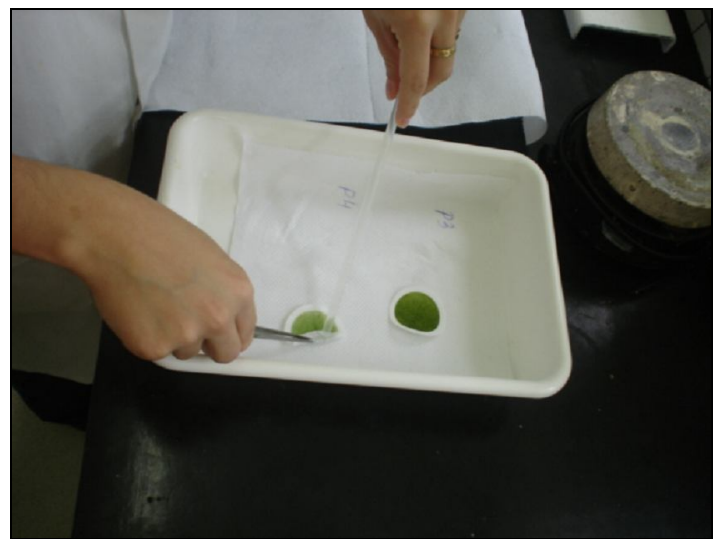

Figura 49: Enrolando o filtro concentrado de clorofila

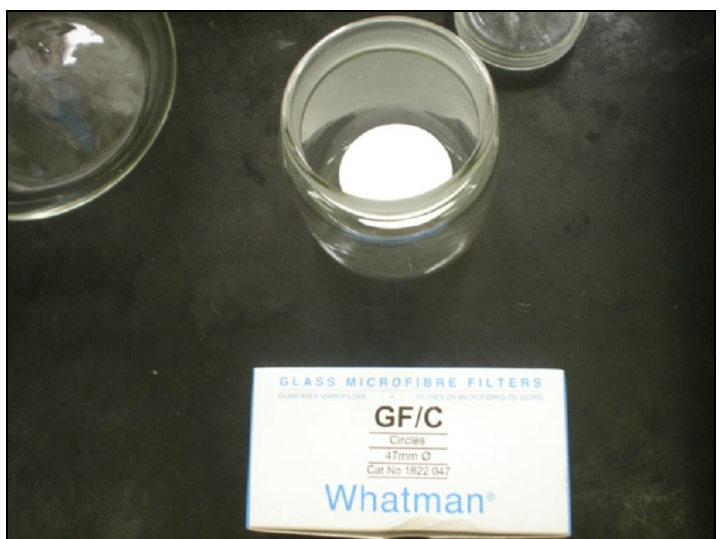

Figura 46: Papel filtro

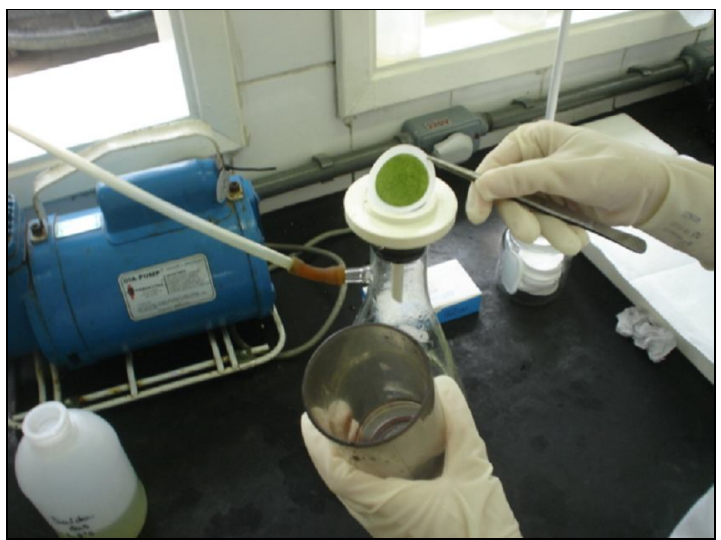

Figura 48: extrato concentrado no filtro

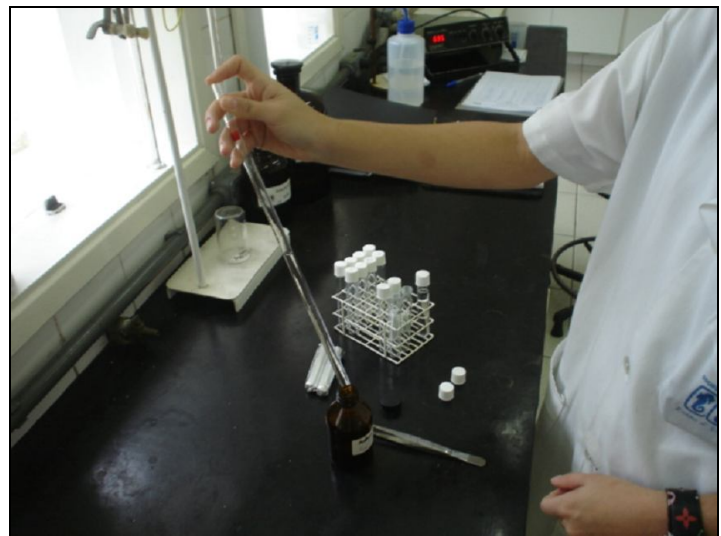

Figura 50: Solução de acetona 90\% para de clorofila extração 


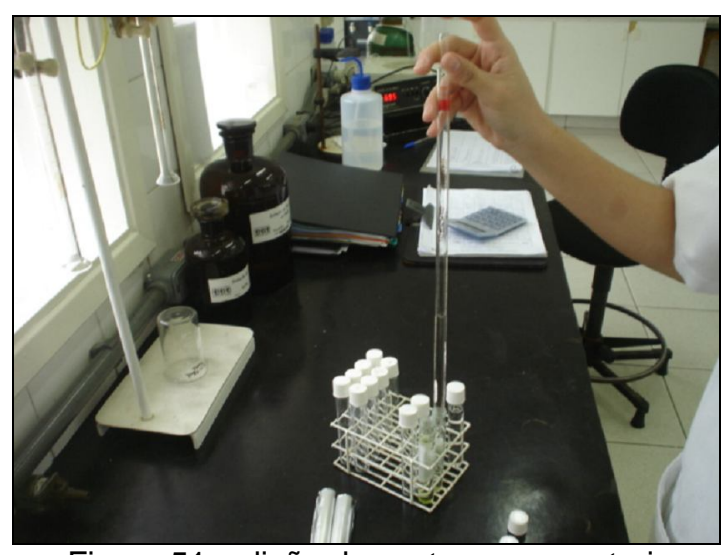

Figura 51: adição de acetona para extrair clorofila concentrada no filtro

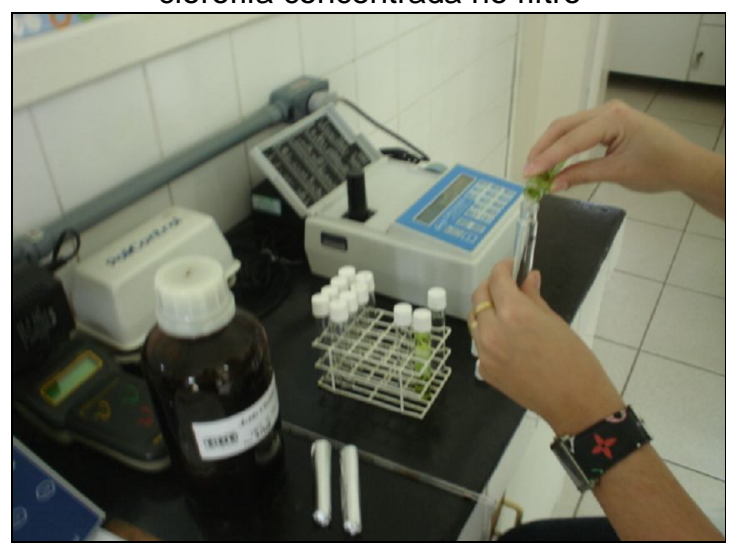

Figura 53: transferência do extrato concentrado no filtro para outro tubo

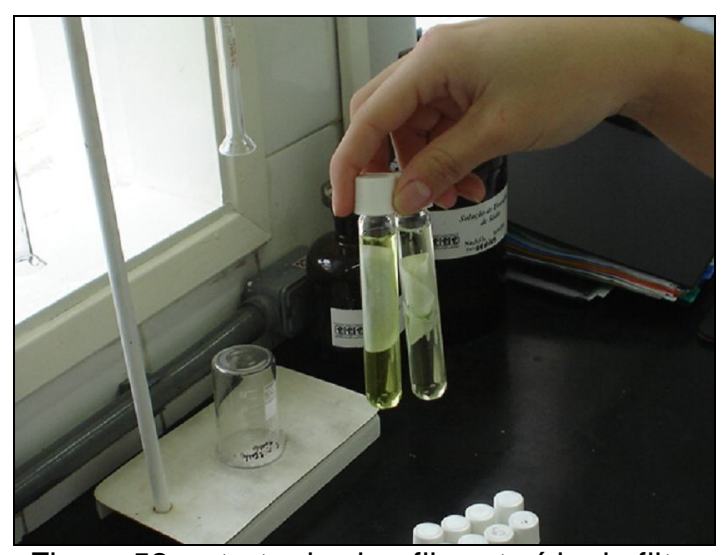

Figura 52: extrato da clorofila extraída do filtro

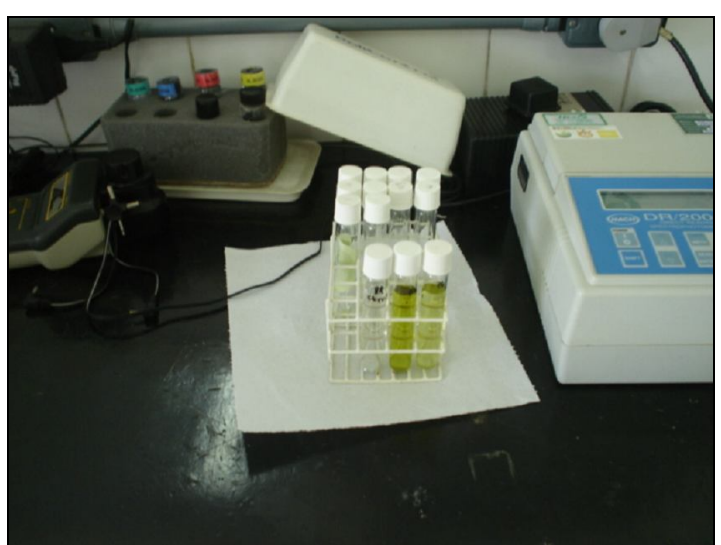

Figura 54: branco e extrato de clorofila (amostra) depois da acidificação 


\section{RESULTADOS E DISCUSSÃO}

\subsection{Resultado de ocorrência de cianobactérias no sistema de tratamento de esgotos}

\subsubsection{Avaliação qualitativa}

Foram encontradas no sistema as seguintes espécies de cianobactérias: Planktothrix $s p$, Merismopedia sp, Microcystis sp, Phormidium sp, Chroococcus sp, Pseudonabaena sp. Aphanocapsa sp. Ademais, foram analisadas as porcentagens das presenças de cada espécie nas amostras ao longo do sistema para a baixa e alta temporada, no sentido de identificar qual espécie tem maior dificuldade de ser removida, qual espécie aparece com maior freqüência nas amostras e com qual densidade. Foi realizado também um estudo da variabilidade das espécies de cianobactérias ao longo do período para cada etapa do sistema com a finalidade de buscar alguma relação entre a sazonalidade e variação de espécies de cianobactérias.

A Tabela 14 apresenta a distribuição relativa das concentrações de células de espécies de cianobactérias nas lagoas facultativas, maturação, Decantador de algas e saída do sistema na baixa temporada. 
Tabela 14: distribuição relativa média das concentrações de células de espécies de cianobactérias para baixa temporada.

\begin{tabular}{|c|c|c|c|c|c|}
\hline $\begin{array}{c}\text { BAIXA } \\
\text { TEMPORADA }\end{array}$ & $\begin{array}{c}\text { SAÍDA DAS } \\
\text { LAGOAS } \\
\text { FACULTATIVAS }\end{array}$ & $\begin{array}{c}\text { SAÍDA DA } \\
\text { LAGOA DE } \\
\text { MATURAÇÃO }\end{array}$ & $\begin{array}{c}\text { SAÍDA DO } \\
\text { DECANTADOR } \\
\text { DE ALGAS }\end{array}$ & $\begin{array}{l}\text { SAÍDA DO } \\
\text { SISTEMA }\end{array}$ & $\begin{array}{c}\text { Eficiência } \\
(\%)\end{array}$ \\
\hline Planktothrix sp & $5,04 \mathrm{E}+03$ & $6,66 \mathrm{E}+03$ & $3,58 \mathrm{E}+03$ & $4,75 \mathrm{E}+03$ & 5,75 \\
\hline Merismopedia sp & $5,77 \mathrm{E}+03$ & $5,96 \mathrm{E}+03$ & $1,10 \mathrm{E}+03$ & $1,65 \mathrm{E}+03$ & 71,40 \\
\hline Microcystis sp & $3,86 \mathrm{E}+03$ & $0,00 \mathrm{E}+00$ & $0,00 \mathrm{E}+00$ & $0,00 \mathrm{E}+00$ & 100,00 \\
\hline Phormidium $s p$ & $1,05 \mathrm{E}+03$ & $0,00 \mathrm{E}+00$ & $0,00 \mathrm{E}+00$ & $0,00 \mathrm{E}+00$ & 100,00 \\
\hline Chroococcus sp & $0,00 \mathrm{E}+00$ & $0,00 \mathrm{E}+00$ & $0,00 \mathrm{E}+00$ & $0,00 \mathrm{E}+00$ & 0,00 \\
\hline Pseudonabaena sp & $0,00 \mathrm{E}+00$ & $0,00 \mathrm{E}+00$ & $0,00 \mathrm{E}+00$ & $0,00 \mathrm{E}+00$ & 0,00 \\
\hline Aphanocapsa sp & $3,16 \mathrm{E}+03$ & $3,73 \mathrm{E}+03$ & $0,00 \mathrm{E}+00$ & $0,00 \mathrm{E}+00$ & 100,00 \\
\hline
\end{tabular}

Os gráficos das Figuras 55, 56, 57 e 58 relativos à Tabela 14, ilustram a divisão média das espécies de cianobactérias ao longo do sistema na baixa temporada.

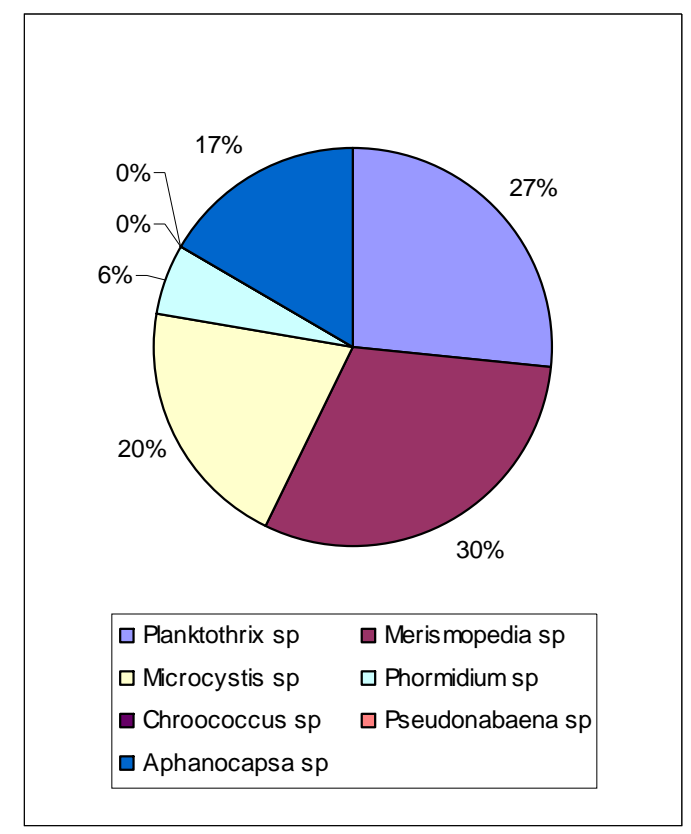

Figura 55: distribuição relativa das densidades de cianobactérias na saída das lagoas facultativas na baixa temporada.

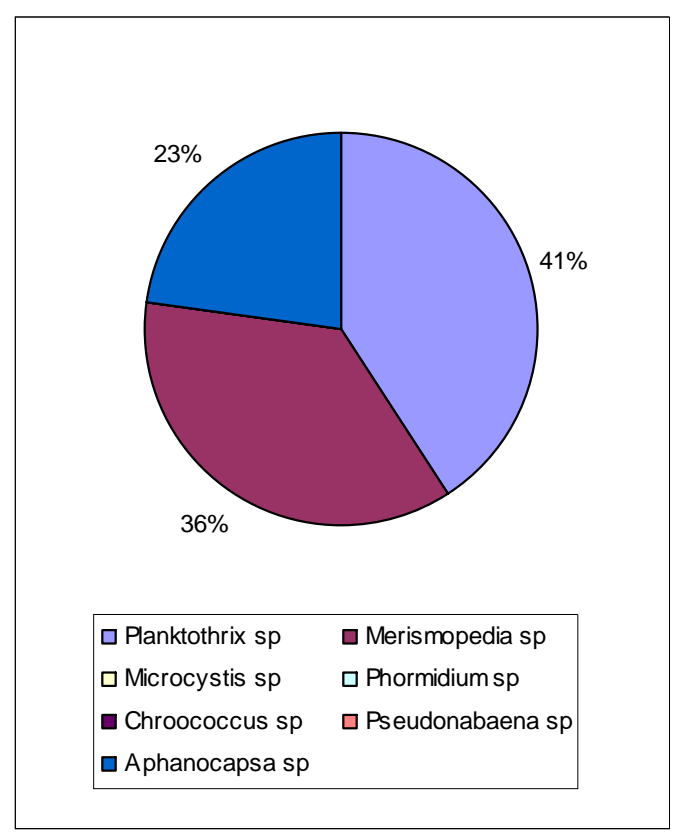

Figura 56: distribuição relativa das densidades de cianobactérias na saída da lagoa de maturação na baixa temporada. 


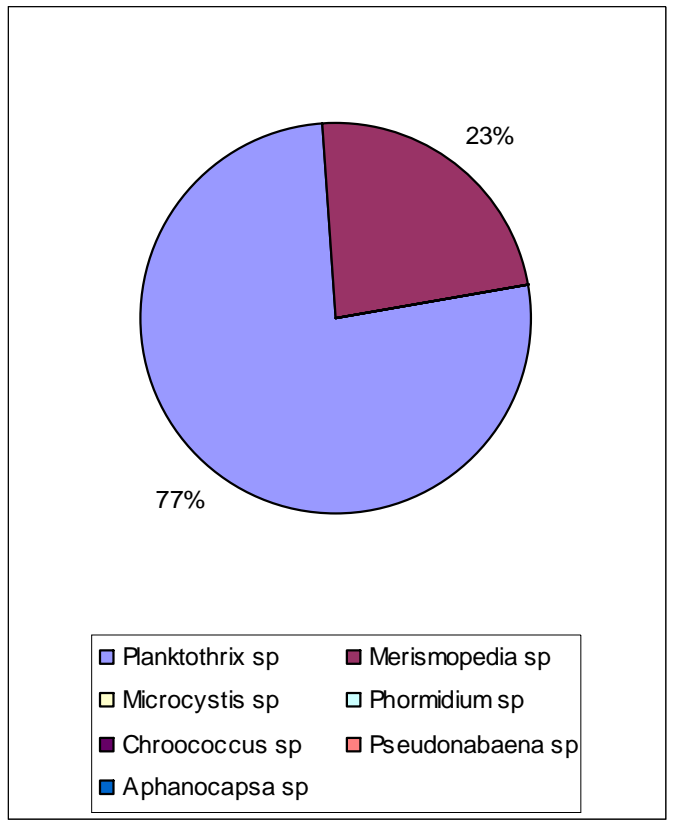

Figura 57: distribuição relativa das densidades de cianobactérias na saída do Decantador de algas na baixa temporada.

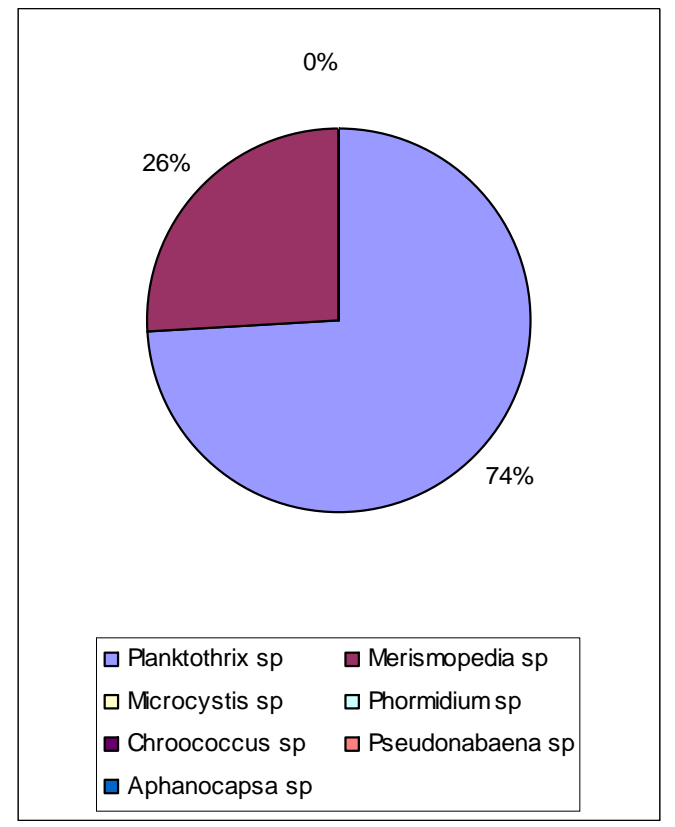

Figura 58: distribuição relativa das densidades de cianobactérias na saída do sistema na baixa temporada.

A Tabela 14 e as Figuras 55, 56, 57 e 58, apontam para uma tendência da espécie Planktothrix sp.ter maior resistência à remoção as que as demais, sendo que a mesma teve a menor eficiência média de remoção ao longo do processo $(5,75 \%)$, sendo que a Merismopedia sp.também se mostrou na média com maior resistência que as outras espécies $(71,40 \%)$, pois, as outras espécies encontradas na baixa temporada Microcystis sp, Phormidium sp.e Aphanocapsa sp.tiveram remoção total, Vale observar que não foram encontradas Pseudonabaena sp.e Chroococcus sp.na baixa temporada.

$\mathrm{Na}$ lagoa de maturação em relação as lagoas facultativas demonstra-se uma certa estabilidade por espécie em relação a densidade de cianobactérias encontradas, porém, na média, obteve-se um pequeno decaimento total em função de duas espécies não serem encontradas na lagoa de maturação, Microcystis $s p$, Phormidium sp.

No Decantador de algas em relação a lagoa de maturação, obtiveram-se os seguintes resultados de eficiência média por espécies, Planktothrix sp.(46,25\%), Merismopedia sp.(81,54\%) e Aphanocapsa sp.(100\%). 
As quantidades encontradas na baixa temporada tanto ao longo das lagoas quanto principalmente na saída do tratamento refletem valores sempre abaixo em relação à nova legislação CONAMA № 357/05 no que tange ao limite de cianobactérias para águas classe I, II e III, são eles $20000 \mathrm{cel} / \mathrm{mL}, 50000 \mathrm{cel} / \mathrm{mL}$ e $100000 \mathrm{cel} / \mathrm{mL}$, respectivamente.

A Tabela 15 apresenta a distribuição relativa das concentrações de células de espécies de cianobactérias nas lagoas facultativas, maturação, Decantador de algas e saída do sistema na alta temporada.

Tabela 15: distribuição relativa média das concentrações de células de espécies de cianobactérias para alta temporada.

\begin{tabular}{lccccc}
\hline ALTA TEMPORADA & $\begin{array}{c}\text { SAÍDA DAS } \\
\text { LAGOAS } \\
\text { FACULTATIVAS }\end{array}$ & $\begin{array}{c}\text { SAÍDA DA } \\
\text { LAGOA DE } \\
\text { MATURAÇÃo }\end{array}$ & $\begin{array}{c}\text { SAÍDA DO } \\
\text { DECANTADOR } \\
\text { DE ALGAS }\end{array}$ & $\begin{array}{c}\text { SAÍ́A Do } \\
\text { SISTEMA }\end{array}$ & $\begin{array}{c}\text { Eficiência } \\
(\%)\end{array}$ \\
\hline Planktothrix $s p$ & $5,27 \mathrm{E}+03$ & $4,17 \mathrm{E}+03$ & $2,63 \mathrm{E}+03$ & $2,91 \mathrm{E}+03$ & 44,78 \\
Merismopedia $s p$ & $5,93 \mathrm{E}+03$ & $6,58 \mathrm{E}+03$ & $9,21 \mathrm{E}+03$ & $0,00 \mathrm{E}+00$ & 100,00 \\
Microcystis sp & $0,00 \mathrm{E}+00$ & $0,00 \mathrm{E}+00$ & $0,00 \mathrm{E}+00$ & $0,00 \mathrm{E}+00$ & 0,00 \\
Phormidium sp & $1,36 \mathrm{E}+04$ & $0,00 \mathrm{E}+00$ & $0,00 \mathrm{E}+00$ & $0,00 \mathrm{E}+00$ & 100,00 \\
Chroococcus $s p$ & $4,39 \mathrm{E}+02$ & $1,32 \mathrm{E}+03$ & $0,00 \mathrm{E}+00$ & $0,00 \mathrm{E}+00$ & 100,00 \\
Pseudonabaena $s p$ & $1,10 \mathrm{E}+03$ & $1,10 \mathrm{E}+03$ & $0,00 \mathrm{E}+00$ & $0,00 \mathrm{E}+00$ & 100,00 \\
Aphanocapsa $s p$ & $0,00 \mathrm{E}+00$ & $0,00 \mathrm{E}+00$ & $0,00 \mathrm{E}+00$ & $0,00 \mathrm{E}+00$ & 0,00 \\
\hline
\end{tabular}

Os gráficos das Figuras 59, 60, 61 e 62, relativos à Tabela 15, ilustram a divisão das espécies de cianobactérias ao longo do sistema na alta temporada. 


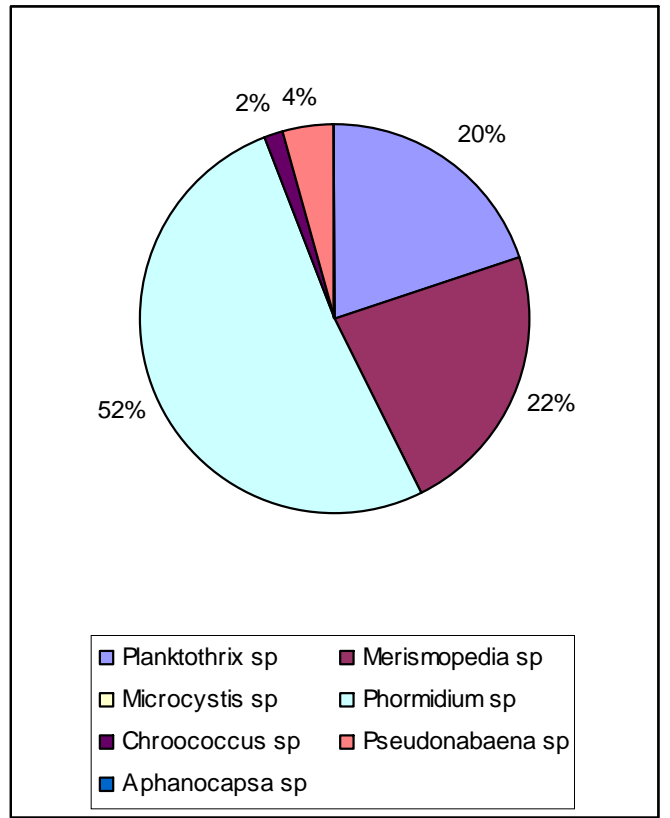

Figura 59: distribuição relativa das densidades de cianobactérias na saída das lagoas facultativas na alta temporada.

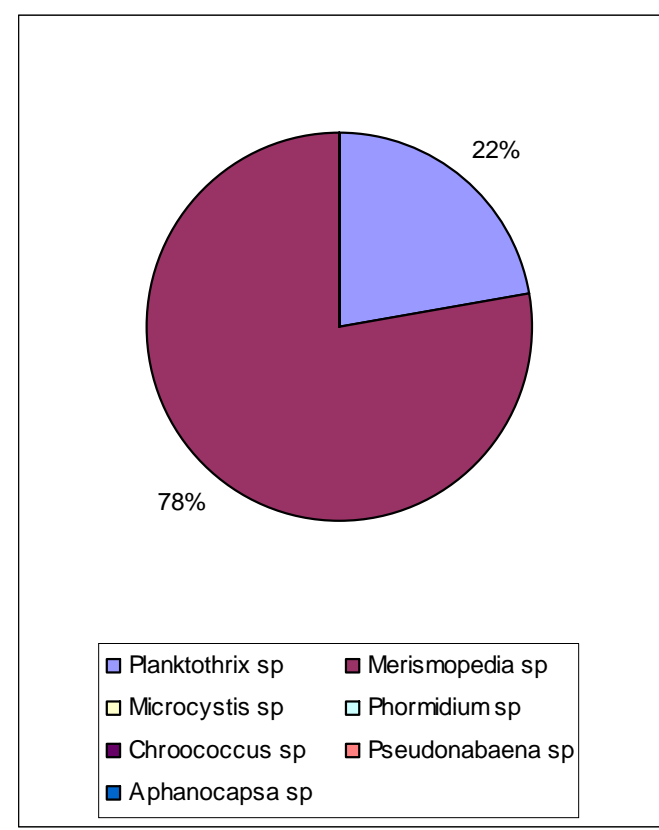

Figura 61: distribuição relativa das densidades de cianobactérias na saída do Decantador de algas na alta temporada.

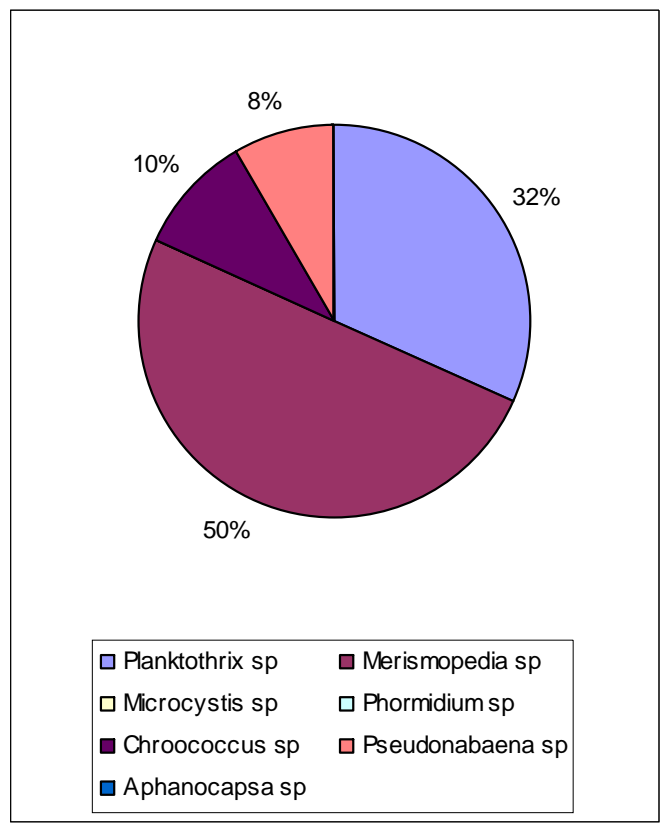

Figura 60: distribuição relativa das densidades de cianobactérias na saída da lagoa de maturação na alta temporada.

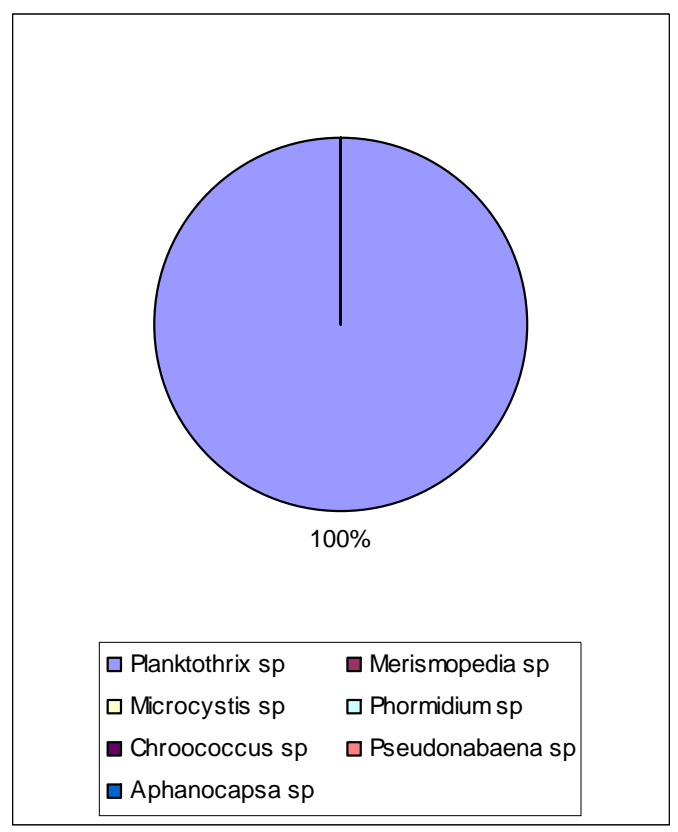

Figura 62: distribuição relativa das densidades de cianobactérias na saída do sistema na alta temporada.

Na Tabela 15 e as Figuras 59, 60, 61 e 62, aponta-se para uma tendência da espécie Planktothrix sp.novamente (agora na alta temporada) demonstrar maior 
resistência à remoção ao tratamento que as demais (44,78\%), onde somente ela foi encontrada na saída do tratamento, além de Microcystis sp.e Aphanocapsa sp.não serem encontradas no processo na alta temporada, as demais espécies tiveram $100 \%$ de remoção.

$\mathrm{Na}$ lagoa de maturação em relação as lagoas facultativas demonstra-se uma certa estabilidade por espécie em relação a densidade de cianobactérias encontradas, porém, na média, obteve-se um significativo decaimento total em função da espécie Phormidium sp.não ser encontrada na lagoa de maturação, observa-se assim, que tanto na baixa com na alta temporada a espécie Phormidium sp.só aparece nas lagos facultativas.

No Decantador de algas, em relação a lagoa de maturação, obteve-se os seguintes resultados de eficiência média por espécie, Planktothrix sp.(36,93\%), Pseudonabaena sp.(100\%), com exceção da Merismopedia sp.onde não houve remoção, pelo contrário, achou-se valores maiores, deve-se suspeitar da possibilidade destes valores, estarem atrelados a coleta, uma vez que a mesma é pontual.

As quantidades encontradas na alta temporada tanto ao longo das lagoas quanto principalmente na saída do tratamento também refletem números positivos em relação à nova legislação CONAMA № 357/05 no que tange o limite de cianobactérias no despejo para rio classe I, II e III, são eles $20000 \mathrm{cel} / \mathrm{mL}, 50000$ $\mathrm{cel} / \mathrm{mL}$ e $100000 \mathrm{cel} / \mathrm{mL}$, respectivamente.

A Tabela 16 apresenta o total de amostras em cada ponto coletado e a presença de cianobactérias por espécie nas lagoas facultativas, maturação, Decantador de algas e saída do sistema na baixa e alta temporada e em todo o período. 
Tabela 16: total de amostras em cada ponto coletado e a presença de cianobactérias por espécie no sistema.

\begin{tabular}{|c|c|c|c|c|c|c|c|c|}
\hline \multicolumn{9}{|c|}{ BAIXA TEMPORADA } \\
\hline total de amostras & \multicolumn{2}{|l|}{12} & \multicolumn{2}{|c|}{11} & \multicolumn{2}{|l|}{8} & \multicolumn{2}{|l|}{15} \\
\hline ponto & \multicolumn{2}{|c|}{ saída LF's } & \multicolumn{2}{|c|}{ saída LM } & \multicolumn{2}{|c|}{ saída RA } & \multicolumn{2}{|c|}{ saída do sistema } \\
\hline & presença & $\%$ & presença & $\%$ & presença & $\%$ & presença & $\%$ \\
\hline Planktothrix sp & 12 & $100 \%$ & 11 & $100 \%$ & 8 & $100 \%$ & 14 & $93 \%$ \\
\hline Merismopedia sp & 9 & $75 \%$ & 8 & $73 \%$ & 2 & $25 \%$ & 1 & $7 \%$ \\
\hline Microcystis sp & 1 & $8 \%$ & 0 & $0 \%$ & 0 & $0 \%$ & 0 & $0 \%$ \\
\hline Phormidium sp & 1 & $8 \%$ & 0 & $0 \%$ & 0 & $0 \%$ & 0 & $0 \%$ \\
\hline Chroococcus sp & 0 & $0 \%$ & 0 & $0 \%$ & 0 & $0 \%$ & 0 & $0 \%$ \\
\hline Pseudonabaena sp & 0 & $0 \%$ & 0 & $0 \%$ & 0 & $0 \%$ & 0 & $0 \%$ \\
\hline Aphanocapsa sp & 1 & $8 \%$ & 2 & $18 \%$ & 0 & $0 \%$ & 0 & $0 \%$ \\
\hline \multicolumn{9}{|c|}{ ALTA TEMPORADA } \\
\hline total de amostras & \multicolumn{2}{|l|}{5} & \multicolumn{2}{|l|}{4} & \multicolumn{2}{|l|}{2} & \multicolumn{2}{|l|}{5} \\
\hline \multirow[t]{2}{*}{ ponto } & \multicolumn{2}{|c|}{ saída LF's } & \multicolumn{2}{|c|}{ saída LM } & \multicolumn{2}{|c|}{ saída RA } & \multicolumn{2}{|c|}{ saída do sistema } \\
\hline & presença & $\%$ & presença & $\%$ & presença & $\%$ & presença & $\%$ \\
\hline Planktothrix sp & 5 & $100 \%$ & 4 & $100 \%$ & 1 & $50 \%$ & 5 & $100 \%$ \\
\hline Merismopedia sp & 2 & $40 \%$ & 2 & $50 \%$ & 1 & $50 \%$ & 0 & $0 \%$ \\
\hline Microcystis sp & 0 & $0 \%$ & 0 & $0 \%$ & 0 & $0 \%$ & 0 & $0 \%$ \\
\hline Phormidium sp & 1 & $20 \%$ & 0 & $0 \%$ & 0 & $0 \%$ & 0 & $0 \%$ \\
\hline Chroococcus sp & 1 & $20 \%$ & 1 & $25 \%$ & 0 & $0 \%$ & 0 & $0 \%$ \\
\hline Pseudonabaena sp & 1 & $20 \%$ & 1 & $25 \%$ & 0 & $0 \%$ & 0 & $0 \%$ \\
\hline Aphanocapsa sp & 0 & $0 \%$ & 0 & $0 \%$ & 0 & $0 \%$ & 0 & $0 \%$ \\
\hline \multicolumn{9}{|c|}{ PERIODO TOTAL } \\
\hline total de amostras & \multicolumn{2}{|l|}{17} & \multicolumn{2}{|c|}{15} & \multicolumn{2}{|c|}{10} & \multicolumn{2}{|l|}{20} \\
\hline ponto & \multicolumn{2}{|c|}{ saída LF's } & \multicolumn{2}{|c|}{ saída LM } & \multicolumn{2}{|c|}{ saída RA } & \multicolumn{2}{|c|}{ saída do sistema } \\
\hline & presença & $\%$ & presença & $\%$ & presença & $\%$ & presença & $\%$ \\
\hline Planktothrix sp & 17 & $100 \%$ & 15 & $100 \%$ & 9 & $90 \%$ & 19 & $95 \%$ \\
\hline Merismopedia sp & 11 & $65 \%$ & 10 & $67 \%$ & 3 & $30 \%$ & 1 & $5 \%$ \\
\hline Microcystis sp & 1 & $6 \%$ & 0 & $0 \%$ & 0 & $0 \%$ & 0 & $0 \%$ \\
\hline Phormidium sp & 2 & $12 \%$ & 0 & $0 \%$ & 0 & $0 \%$ & 0 & $0 \%$ \\
\hline Chroococcus sp & 1 & $6 \%$ & 1 & $7 \%$ & 0 & $0 \%$ & 0 & $0 \%$ \\
\hline Pseudonabaena sp & 1 & $6 \%$ & 1 & $7 \%$ & 0 & $0 \%$ & 0 & $0 \%$ \\
\hline Aphanocapsa sp & 1 & $6 \%$ & 2 & $13 \%$ & 0 & $0 \%$ & 0 & $0 \%$ \\
\hline
\end{tabular}


Os gráficos das Figuras 63, 64 e 65, relativos à Tabela 16, apontam a presença relativa de espécies de cianobactérias ao longo do sistema.

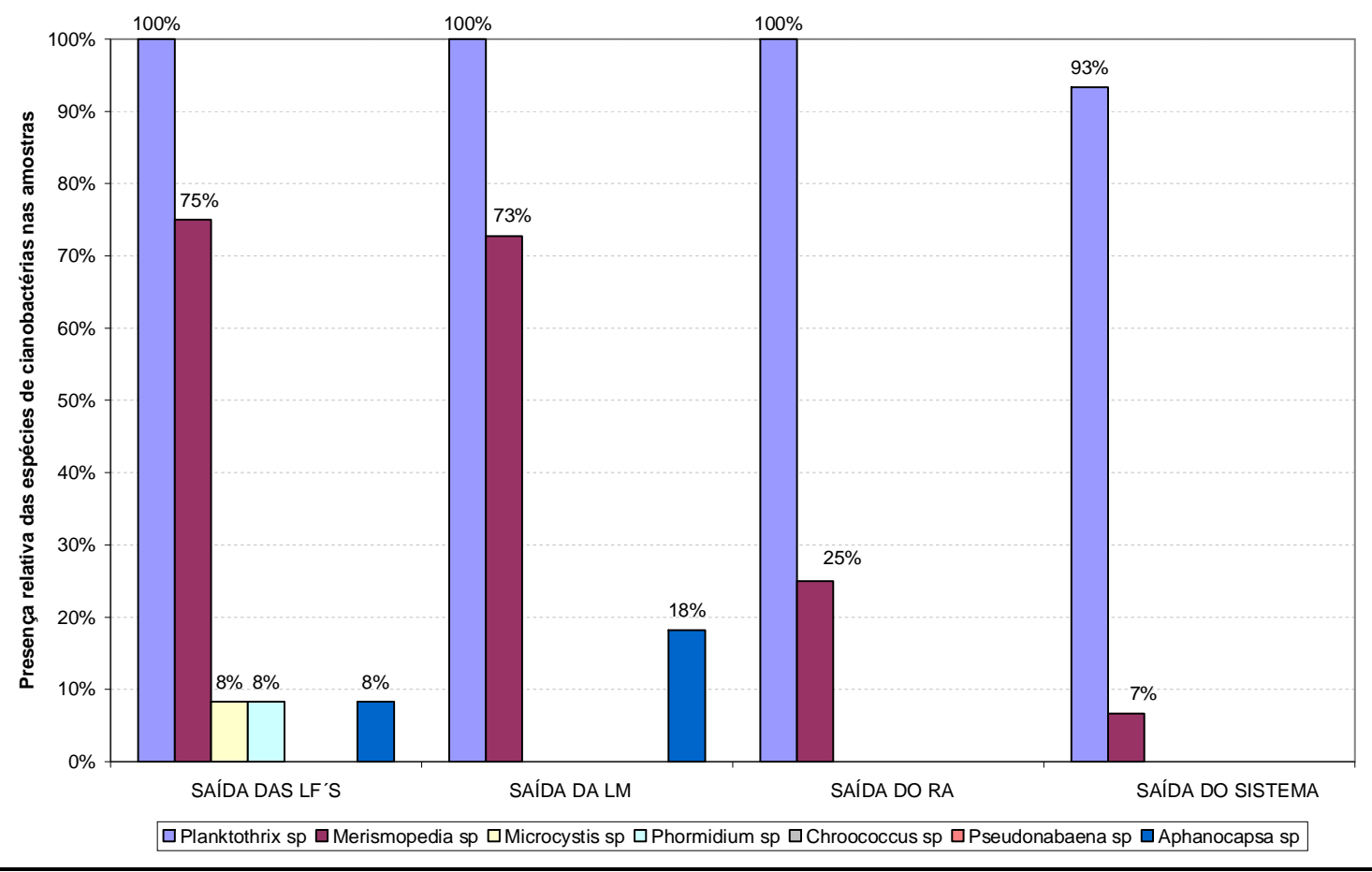

Figura 63: presença relativa de espécies de cianobactérias na baixa temporada.

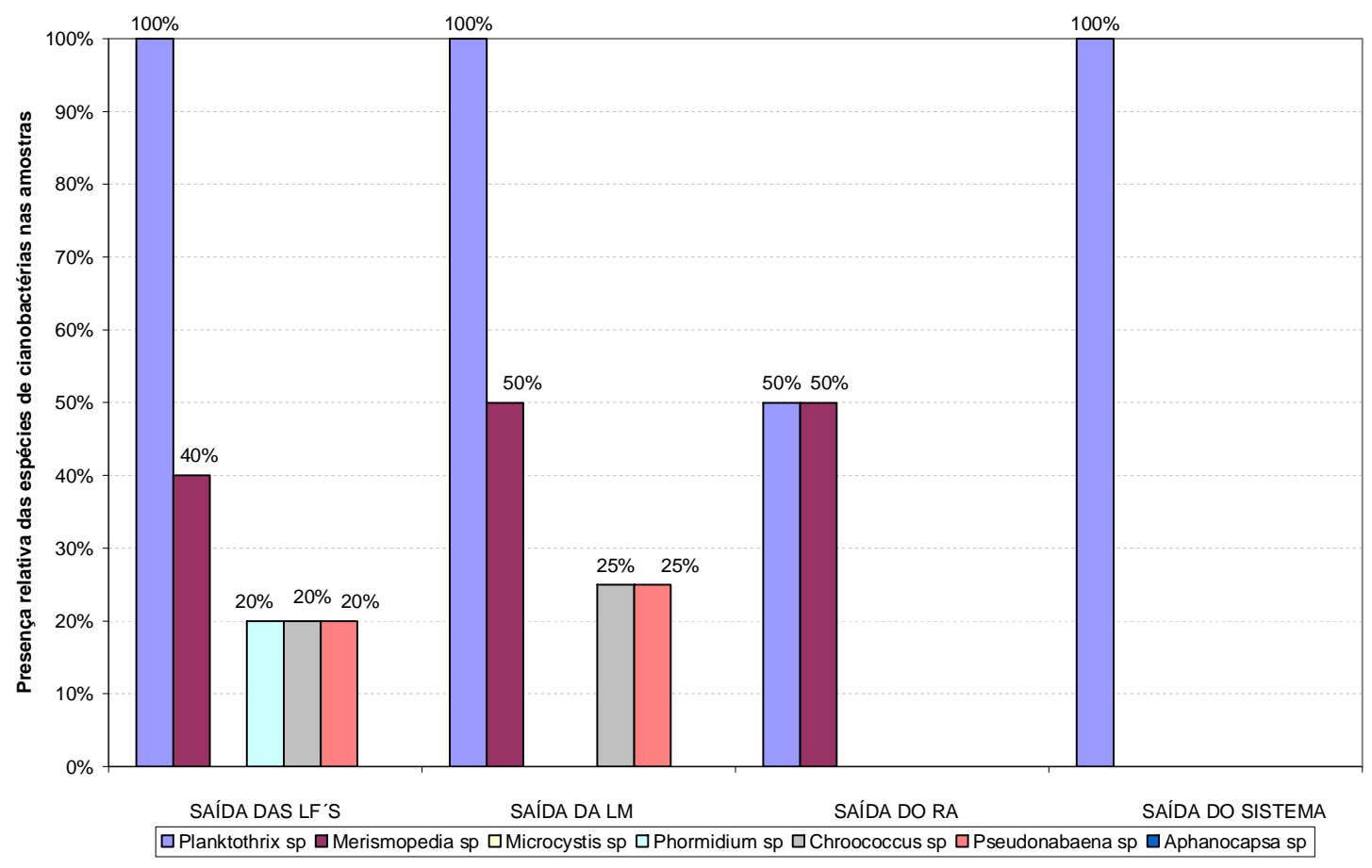


Figura 64: presença relativa de espécies de cianobactérias na alta temporada.

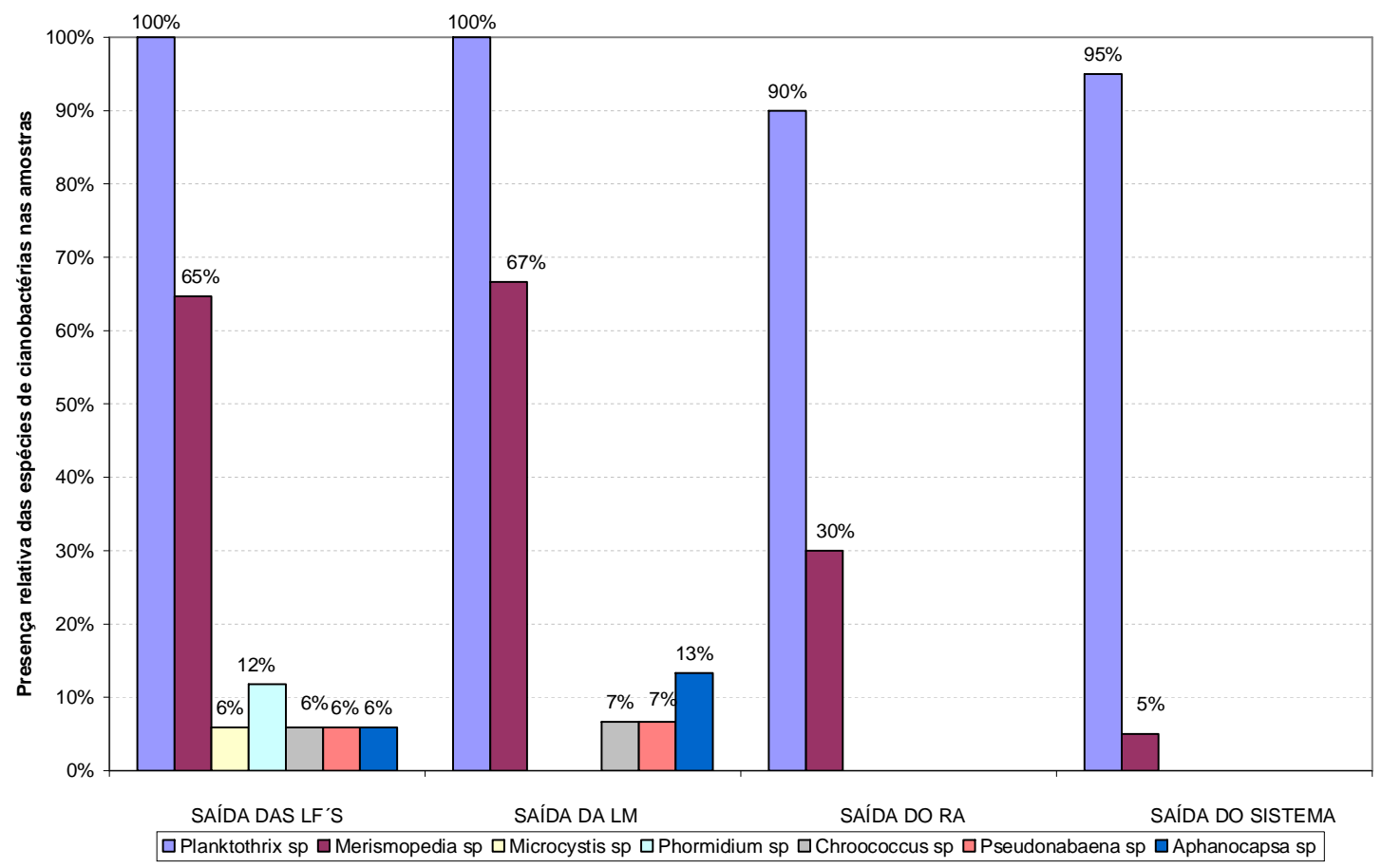

Figura 65: presença relativa de espécies de cianobactérias em todo o período.

A Tabela 16 e as Figuras 63, 64 e 65, apontam que ao longo de todo o período de estudo, as espécies que ocorreram em maior freqüência foram, Planktothrix sp.(90 à100\%) e a Merismopedia sp.(5 à 67\%), demonstrando assim, que as duas espécies são claramente predominantes no sistema estudado. Pode-se observar também, que a Planktothrix sp, tanto na baixa temporada como na alta temporada, possui a maior capacidade de permanecer no sistema com melhor resistência a remoção, seguida pela Merismopedia sp, tanto na parte biológica como na parte físico-química, e que todas as outras espécies são removidas até o Decantador de algas.

$\mathrm{Na}$ Figura 66, são apresentados os valores totais de cianobactérias na saída no sistema ao longo do período estudado, quanto ao respectivo limite para rio classe II. 


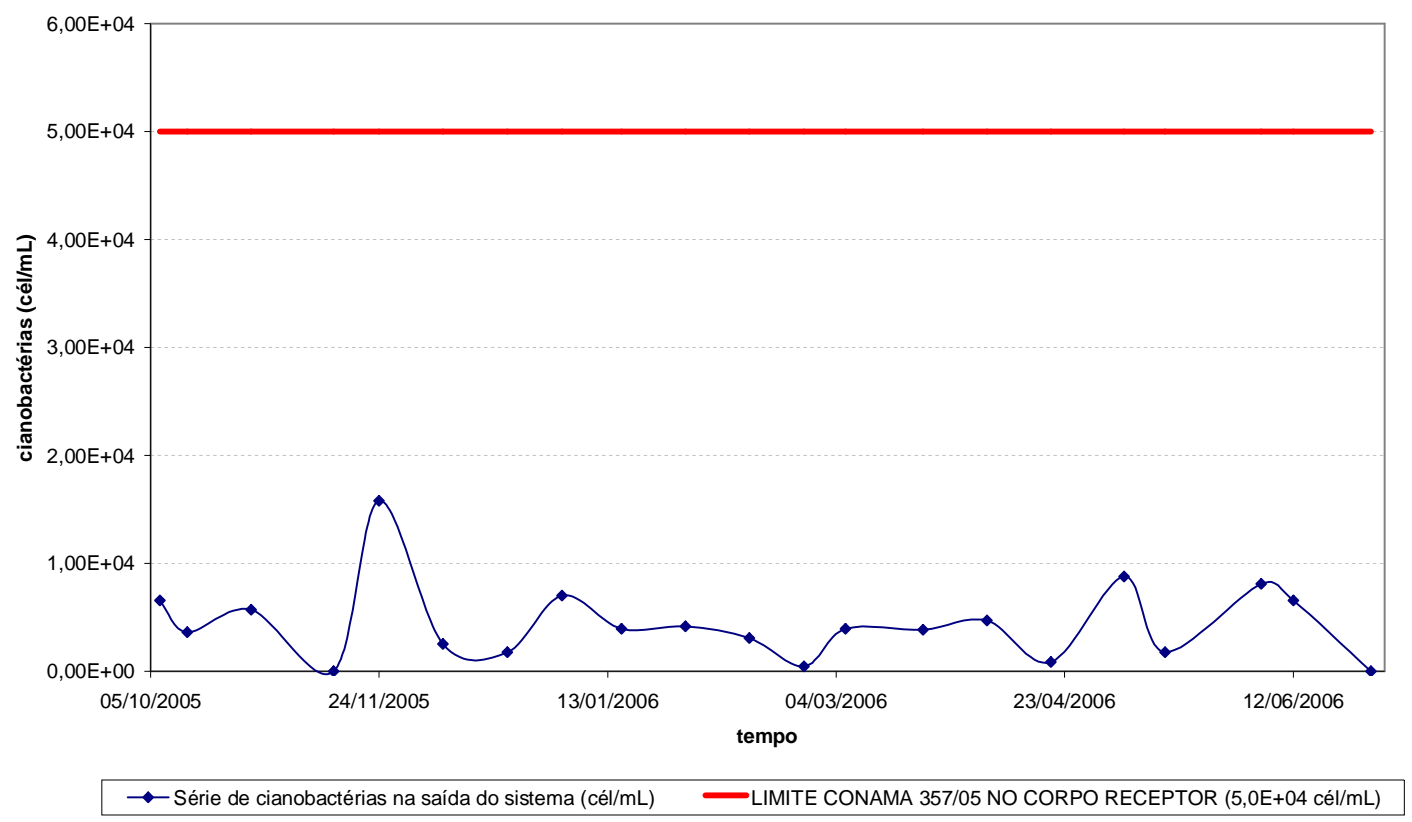

Figura 66: comparação entre a série de valores totais de cianobactérias na saída no sistema ao longo do período estudado e o limite da resolução CONAMA № 357/05 no corpo receptor para rio classe II.

Segundo a Resolução CONAMA 357, o limite para densidade de cianobactérias em rios classe I, II e III é de $20000 \mathrm{cel} / \mathrm{mL}, 50000 \mathrm{cel} / \mathrm{mL}$ e $100000 \mathrm{cel} / \mathrm{mL}$, respectivamente, portanto, de acordo com a Figura 71, toda a série desse parâmetro na saída do sistema encontra-se abaixo desses limites, antes mesmo de considerarse a diluição no corpo receptor.

\subsection{Resultados dos parâmetros físico-químicos, clorofila-a e cianobactérias}

\subsubsection{Avaliação quantitativa parâmetros físico-químicos}

Os parâmetros de suporte e os parâmetros de controle foram submetidos a uma análise de outliers através de um boxplot para cada parâmetro afluente e efluente à estação, no sentido de eliminar os dados que poderiam deteriorar as estatísticas. Os 
outliers foram caracterizados como dados fora do intervalo da mediana mais ou menos três vezes o intervalo inter-quartil (IIQ), sendo o IIQ a diferença entre o primeiro (25\%) e o terceiro quartil $(75 \%)$.

Posteriormente os resultados das amostras foram estatiscamente analisados através dos parâmetros média, mediana e desvio-padrão, onde foram confeccionados gráficos de Box Wiskler e séries temporais, além da eficiência de remoção.

$\mathrm{Na}$ tentativa de relacionar os parâmetros clorofila-a e cianobactérias efluentes com os outros seis parâmetros efluentes, criaram-se gráficos de séries temporais com esses dois parâmetros e mais um terceiro parâmetro no sentido de buscar visualmente algum comportamento semelhante.

As Figuras 67 a 82 apresentam os resultados da análise de outliers de todos os parâmetros afluentes e efluentes.

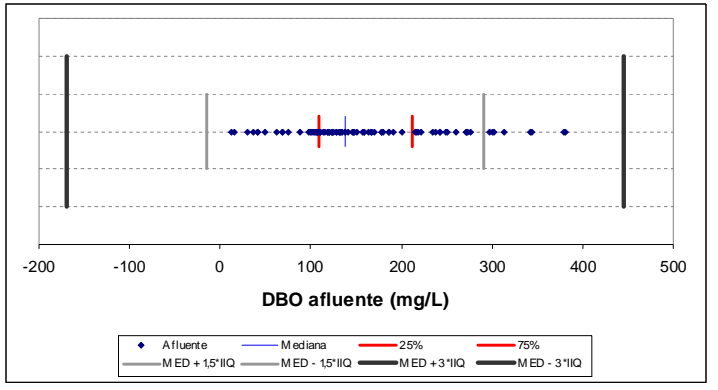

Figura 67: análise de outliers para DBO afluente.

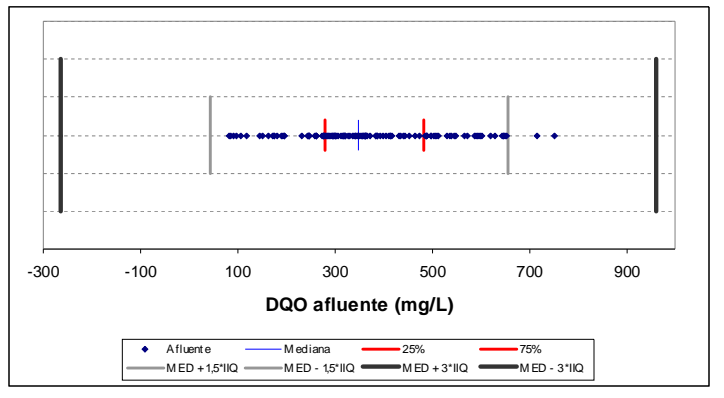

Figura 69: análise de outliers para DQO afluente.

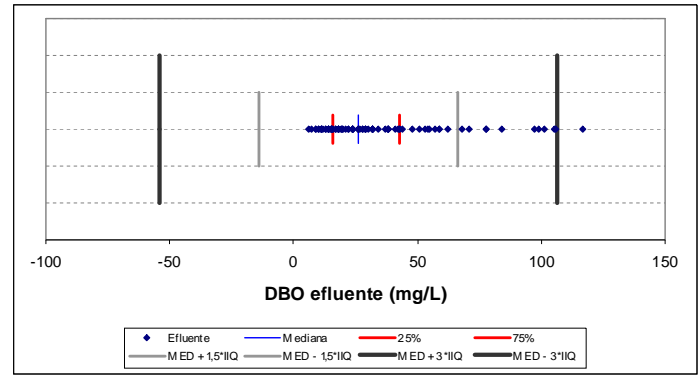

Figura 68: análise de outliers para DBO efluente.

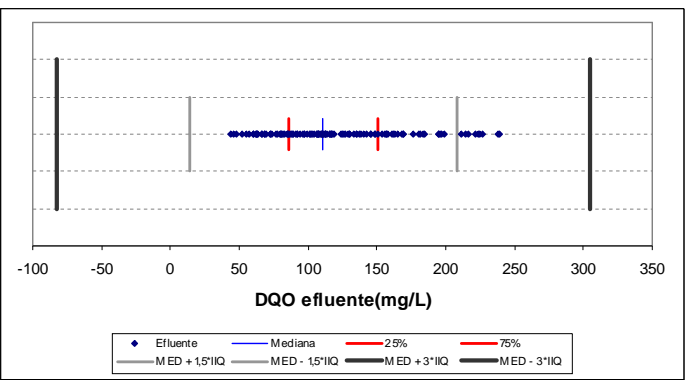

Figura 70: análise de outliers para DQO efluente. 


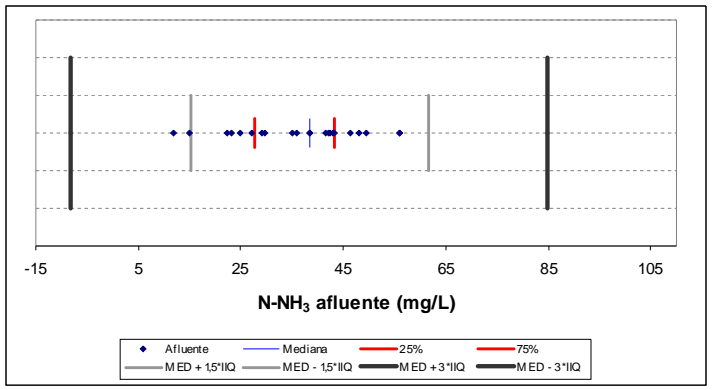

Figura 71: análise de outliers para $\mathrm{N}-\mathrm{NH}_{3}$ afluente.

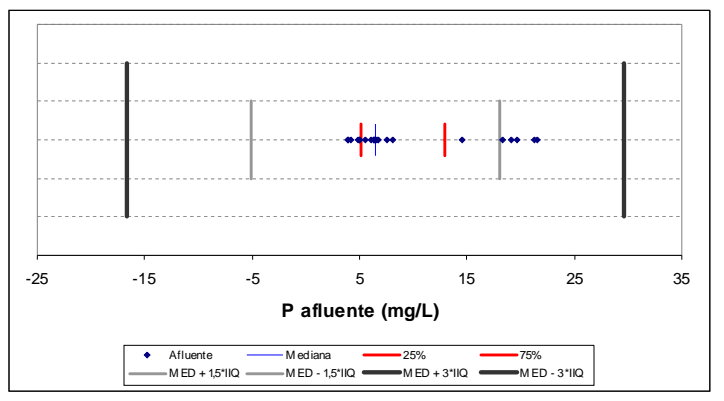

Figura 73: análise de outliers para $\mathrm{P}$ afluente.

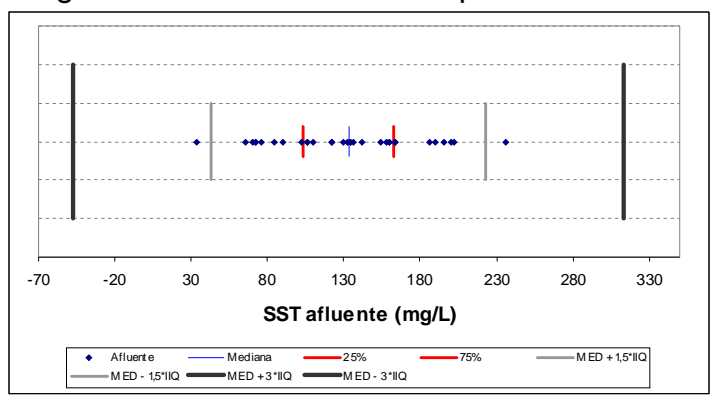

Figura 75: análise de outliers para SST afluente.

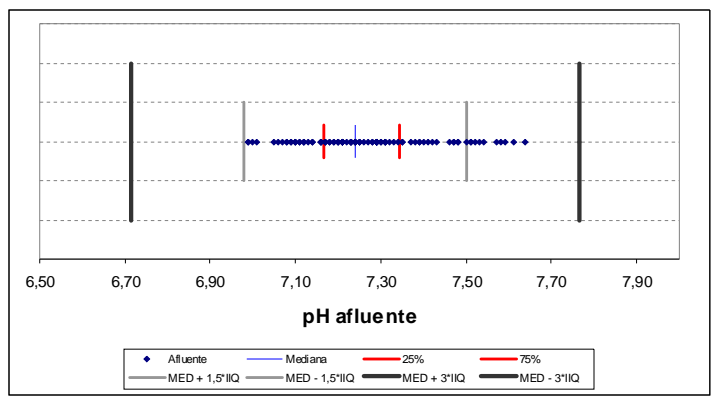

Figura 77: análise de outliers para pH afluente.

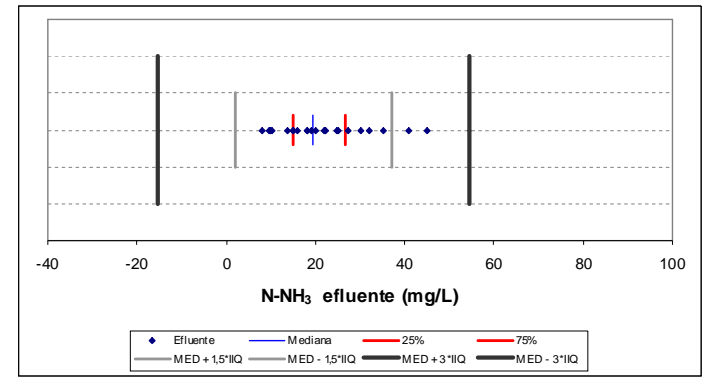

Figura 72: análise de outliers para $\mathrm{N}-\mathrm{NH}_{3}$ efluente.

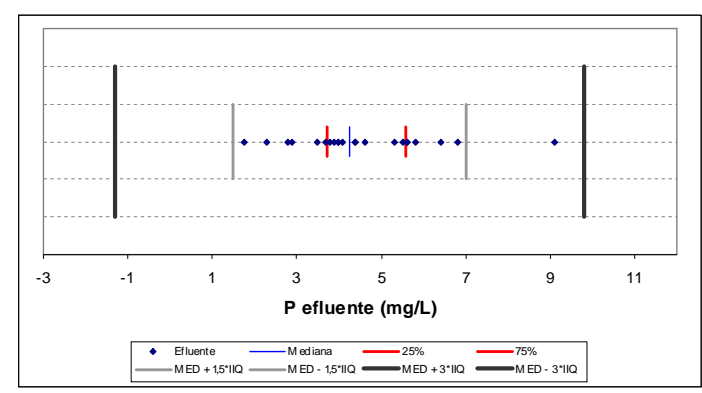

Figura 74: análise de outliers para $\mathrm{P}$ efluente.

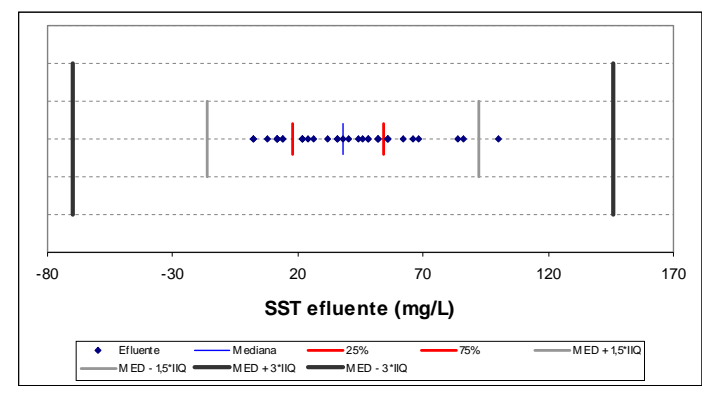

Figura 76: análise de outliers para SST efluente.

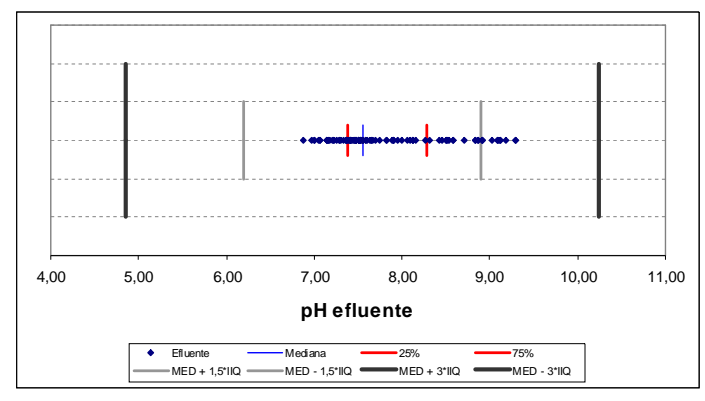

Figura 78: análise de outliers para pH efluente. 


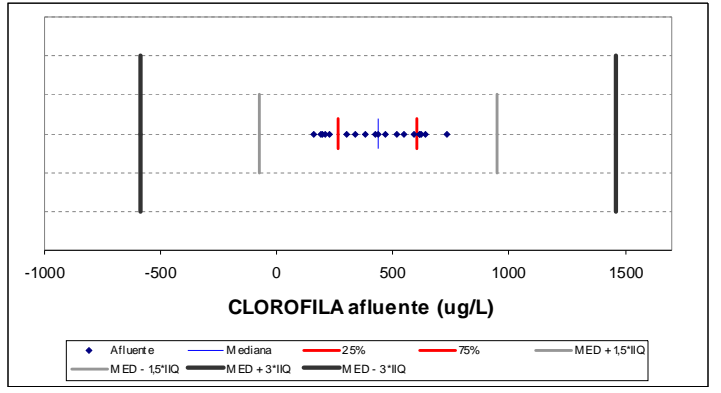

Figura 79: análise de outliers para clorofila-a afluente.

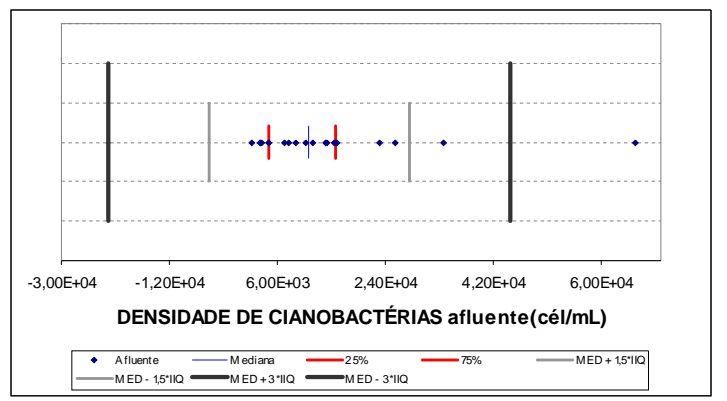

Figura 81: análise de outliers para densidade de cianobactérias afluente.

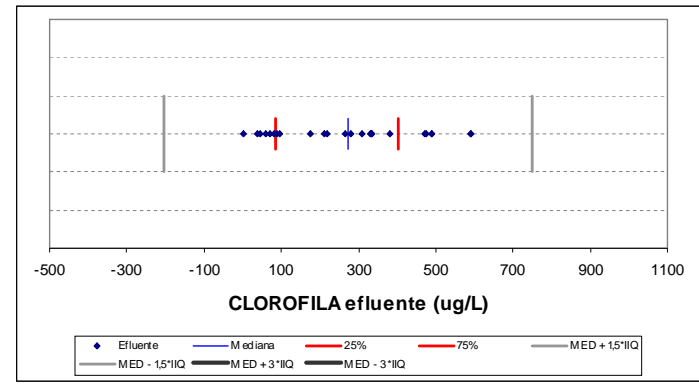

Figura 80: análise de outliers para clorofila-a efluente.

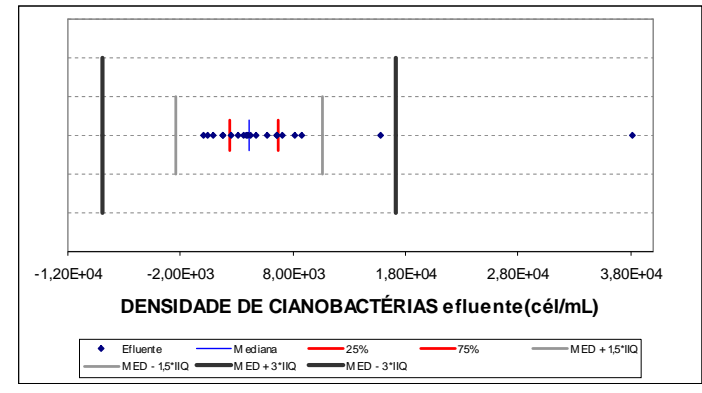

Figura 82: análise de outliers para densidade de cianobactérias efluente.

Nas Figuras 67 a 82, nota-se que apenas os parâmetros DBO e cianobactéria apresentaram outliers .

Nas Figuras 83, 84 e 85, apresentam-se os gráficos sem os outliers, que serão utilizados no estudo.

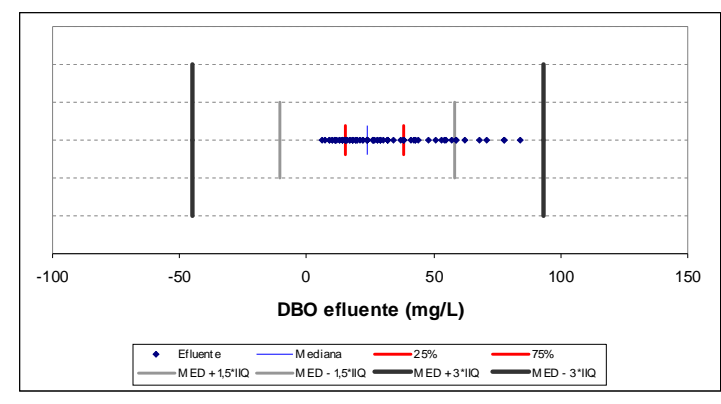

Figura 83: análise de outliers para DBO efluente, sem os outilers. 


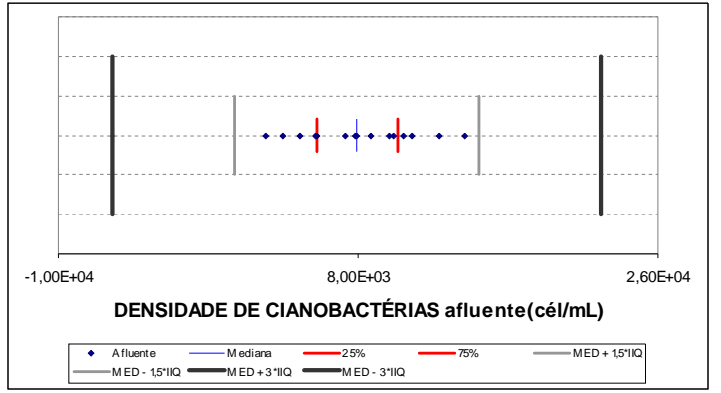

Figura 84: análise de outliers para densidade de cianobactérias afluente, sem o outiler.

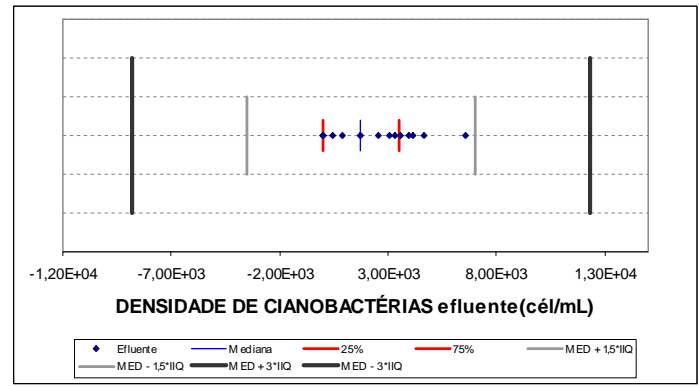

Figura 85: análise de outliers para densidade de cianobactérias efluente, sem o outiler.

Os resultados obtidos através dos gráficos das Figuras 67 a 82 apresentam valores para todos os parâmetros, que podem ser considerados coerentes, uma vez que somente na DBO e cianobactérias encontrou-se outliers, sendo os mesmos removidos, conforme gráficos da Figura 88,89 e 90.

As Figuras 86 a 130 apresentam a série histórica de todos os parâmetros analisados com seus respectivos Box and Wiskers e desvio padrão em relação à concentração e eficiência para entrada e saída do sistema, conforme objetivo específico de avaliar as condições operacionais do sistema. Adotou-se, para a cianobactéria como ponto afluente, a saída das lagoas facultativas e efluente a saída do sistema, para clorofila-a, adotou-se, a saída da lagoa de maturação como afluente e efluente a saída do sistema. Para todas as variáveis de suporte adotouse como ponto afluente à entrada do sistema e efluente a saída do sistema. e efluente a saída do sistema.

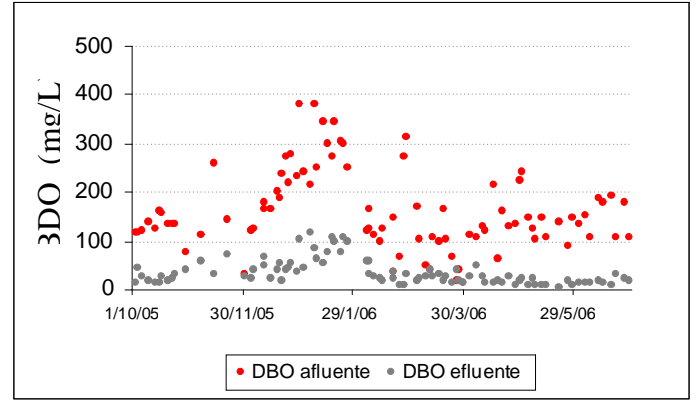

Figura 86: séries temporais de DBO afluente e efluente.

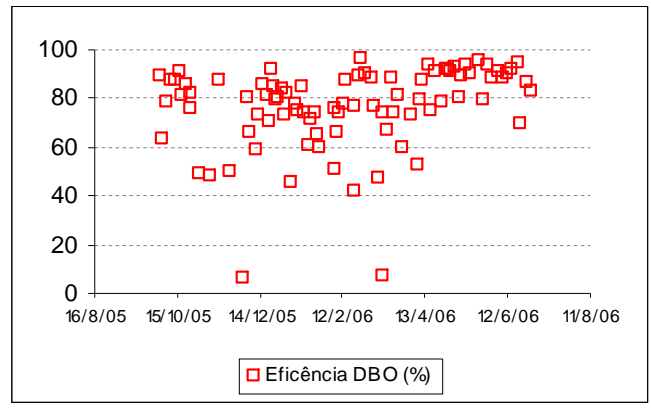

Figura 87: séries temporais da eficiência de remoção de DBO. 


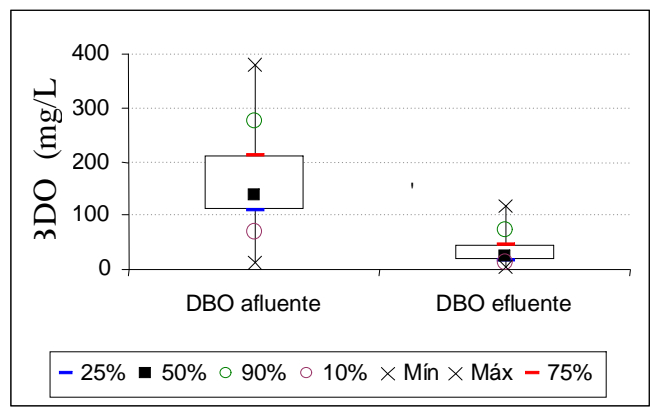

Figura 88: gráfico Box and Wiskers da DBO afluente e efluente.

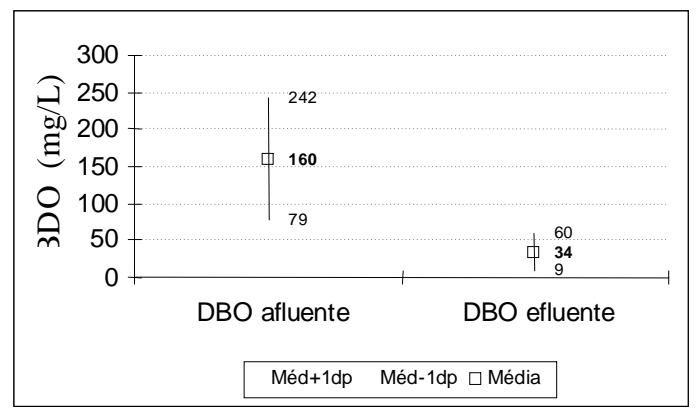

Figura 90: desvio padrão das séries temporais de DBO afluente e efluente.

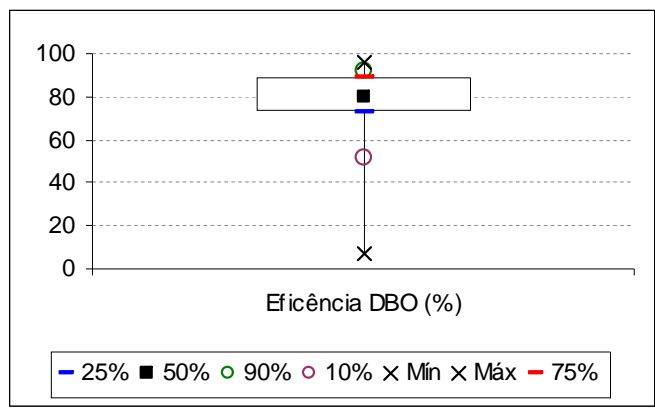

Figura 89: gráfico Box and Wiskers da eficiência de remoção de DBO.

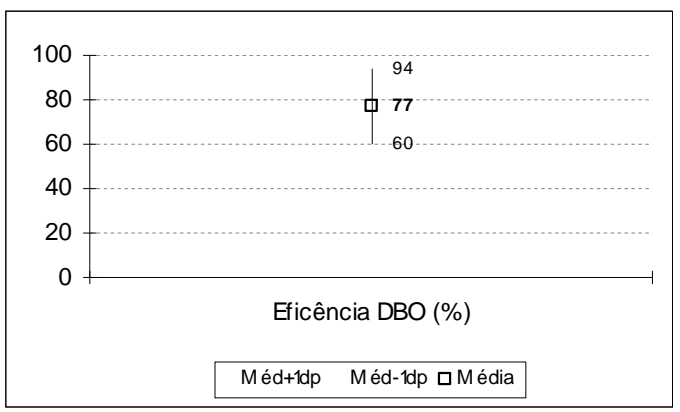

Figura 91: desvio padrão da eficiência de remoção de DBO.

As Figuras 86 a 91 apresentam valores de DBO, onde podem-se notar a variação das concentrações no afluente ao longo do período estudado em função da sazonalidade do sistema, onde os valores de DBO afluentes aumentam nos meses de alta temporada, sendo este perfil de baixa e alta temporada acompanhado pelo efluente conforme Figura 91. Observando o gráficos de Box and Wiskers e desvio padrão, pode-se observar que os valores de afluente caracterizam o esgoto como fraco para médio com uma média de $160 \pm 81 \mathrm{mg} / \mathrm{L}$ (médio $220 \mathrm{mg} / \mathrm{L}$ e fraco 110 $\mathrm{mg} / \mathrm{L}$ conforme Tabela 1), as eficiências mantiveram-se estabilizadas ao longo de todo o período conforme Figura 92, com uma saída média de $34 \pm 25 \mathrm{mg} / \mathrm{L}$, com média de eficiência de remoção de $77 \pm 17 \%$, onde pode-se enquadrar estes resultados do sistema de tratamento de esgotos com as novas mudanças, ou seja, o sistema biológico precedido e sucedido por tratamento físico-químico, como satisfatório em termos de legislação pertinente (decreto 8468/76 - CETESB). 


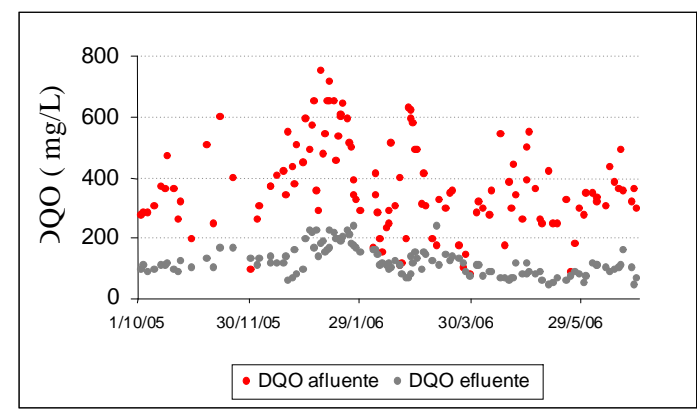

Figura 92: séries temporais de DQO afluente e efluente.

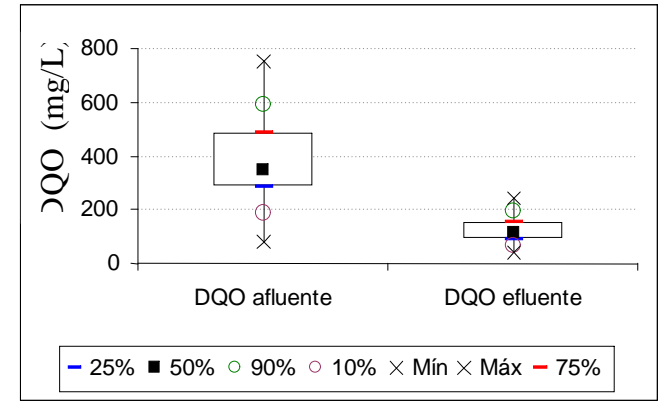

Figura 94: gráfico Box and Wiskers da DQO afluente e efluente.

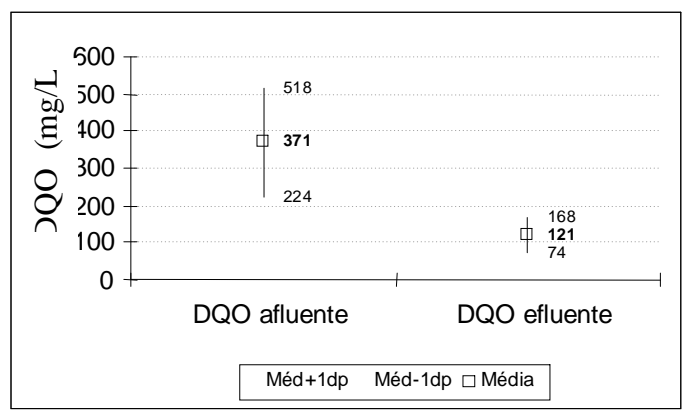

Figura 96: desvio padrão das séries temporais de DQO afluente e efluente.

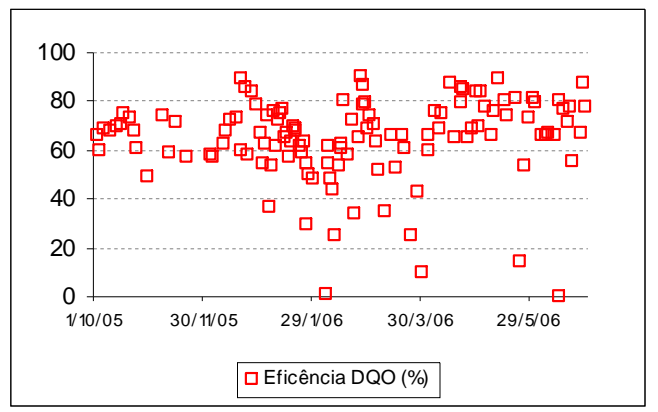

Figura 93: séries temporais da eficiência de remoção de DQO.

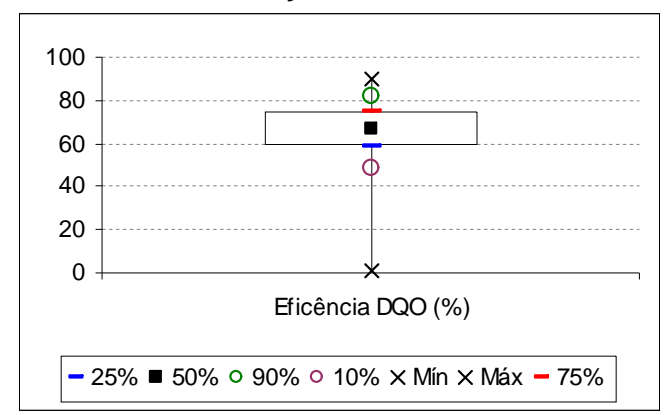

Figura 95: gráfico Box and Wiskers da eficiência de remoção de DQO.

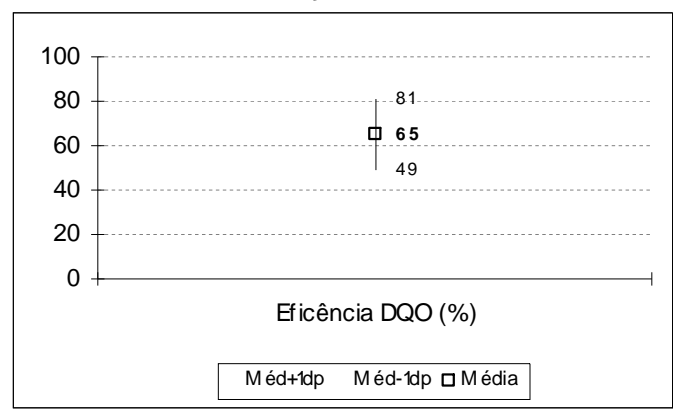

Figura 97: desvio padrão da eficiência de remoção de DQO.

As Figuras 92 a 97 apresentam valores de DQO, onde pode-se notar uma pequena variação da DQO no afluente ao longo do período estudado em função da sazonalidade do sistema, sendo este perfil de baixa e alta temporada acompanhado pelo efluente. Observando o gráficos de Box and Wiskers e desvio padrão, pode-se observar que os valores de DQO afluente caracterizam o esgoto como médio para fraco com uma média de $371 \pm 147 \mathrm{mg} / \mathrm{L}$ (médio $500 \mathrm{mg} / \mathrm{L}$ e fraco $250 \mathrm{mg} / \mathrm{L}$ conforme Tabela 1), as eficiências mantiveram-se estabilizadas ao longo de todo 0 período conforme Figura 98, com uma saída média de $121 \pm 47 \mathrm{mg} / \mathrm{L}$, com média de eficiência de remoção de $65 \pm 16 \%$, pode-se notar que há coerência nos dados de DBO em relação a DQO, com uma relação média entre os dois parâmetros de 1:2,3, 
levando-se em conta que trata-se de um esgoto com características de esgoto doméstico. Pode-se, então enquadrar estes resultados de DQO do sistema de tratamento de esgotos com as novas mudanças, ou seja, o sistema biológico precedido e sucedido por tratamento físico-químico, como satisfatório.

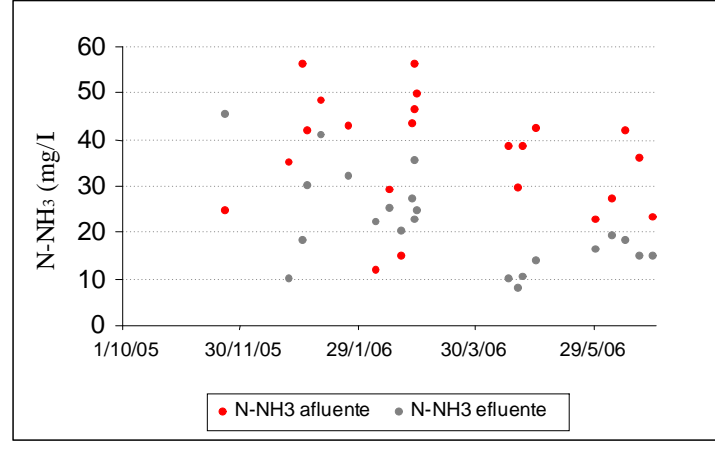

Figura 98: séries temporais de $\mathrm{N}-\mathrm{NH}_{3}$ afluente e efluente.

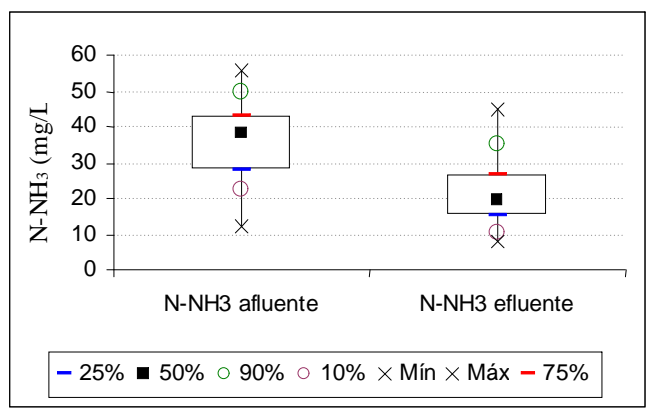

Figura 100: gráfico Box and Wiskers de $\mathrm{N}-\mathrm{NH}_{3}$ afluente e efluente.

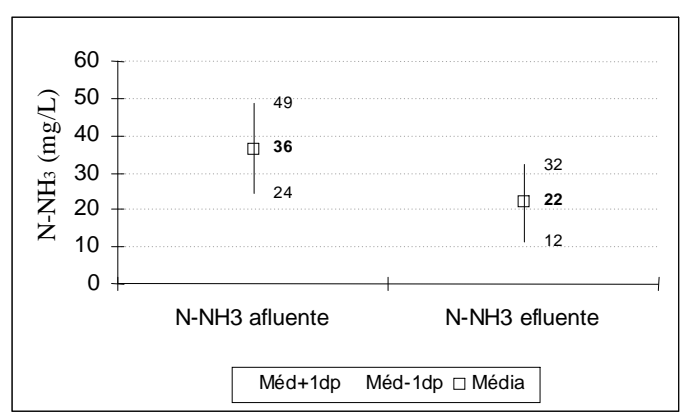

Figura 102: desvio padrão das séries temporais de $\mathrm{N}-\mathrm{NH}_{3}$ afluente e efluente.

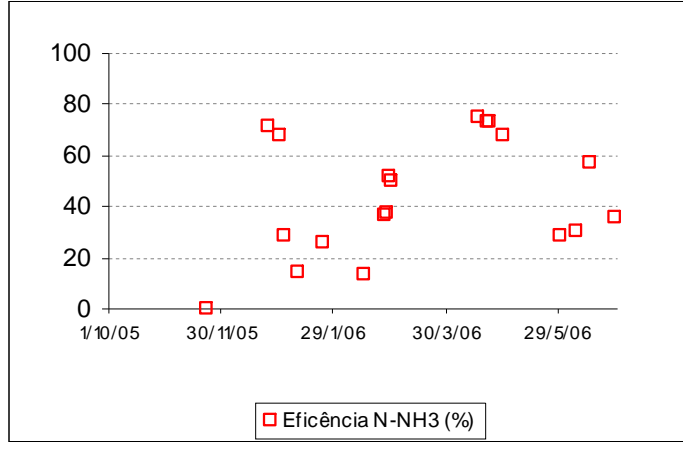

Figura 99: séries temporais da eficiência de remoção de $\mathrm{N}-\mathrm{NH}_{3}$.

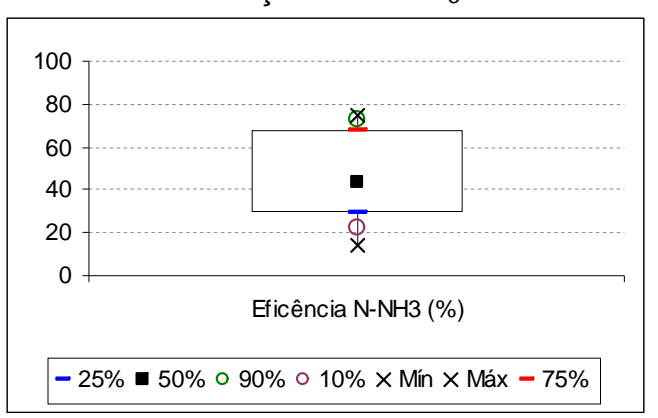

Figura 101: gráfico Box and Wiskers da eficiência de remoção de $\mathrm{N}-\mathrm{NH}_{3}$.

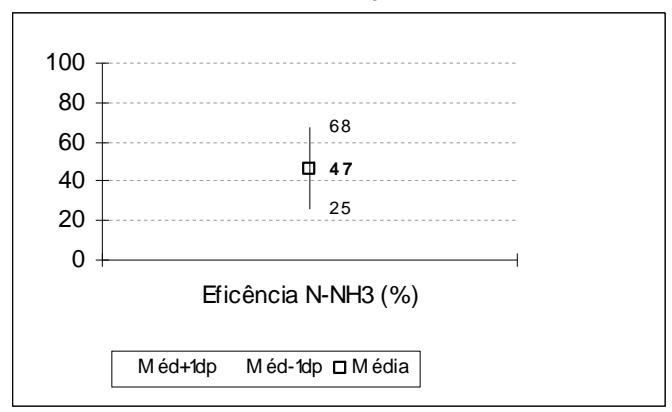

Figura 103: desvio padrão da eficiência de remoção de $\mathrm{N}-\mathrm{NH}_{3}$.

As Figuras 98 a 103 apresentam valores de nitrogênio amoniacal do esgoto estudado, onde pode-se notar duas situações, uma em relação a sazonalidade e outra em relação a aplicação de cal hidratada. $\mathrm{Na}$ alta temporada observar-se um aumento da concentração de nitrogênio amoniacal no afluente e efluente, provavelmente em função do aumento da população, conforme gráfico da série 
temporal da Figura 98, na eficiência, Figura 99, nota-se ainda um decaimento na remoção do nitrogênio amoniacal neste mesmo período (alta temporada), provavelmente em função da diminuição do tempo de detenção do sistema.

Nota-se, também, uma acentuada melhora conforme Figura 99, da eficiência a partir de fevereiro de 2006, data esta que se iniciou a aplicação de cal hidratada no Decantador de algas, anteriormente utilizava-se, somente polímero catiônico, e a partir desta data (fevereiro/2006) passou-se a utilizar os dois, polímero catiônico (1 À 2,5 mg/L) seguido de cal hidratada com uma relação de 1:25 com o polímero, no caso, variando de $25 \mathrm{mg} / \mathrm{L}$ à $62,5 \mathrm{mg} / \mathrm{L}$. Apesar dos resultados não satisfazerem a legislação durante todo o período de estudo(decreto 8468/76 - CETESB), obteve-se média de $45 \pm 14 \mathrm{mg} / \mathrm{L}$ no afluente, caracterizando-o como esgoto médio (40 mg/L Tabela 1), com média de saída de $22 \pm 10 \mathrm{mg} / \mathrm{L}$ no efluente, a eficiência mostrou-se na ordem de $47 \pm 21 \%$.

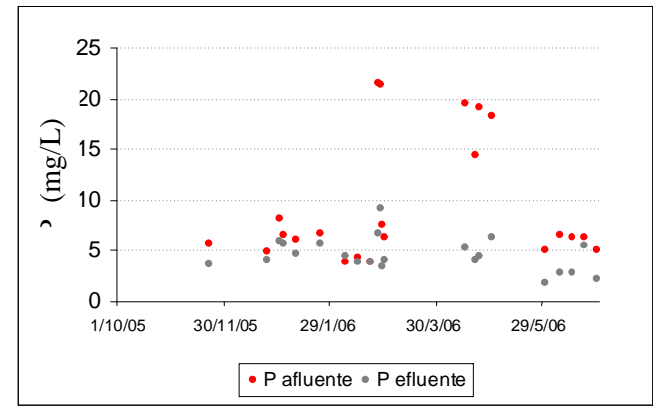

Figura 104: séries temporais de $\mathrm{P}$ afluente $\mathrm{e}$ efluente.

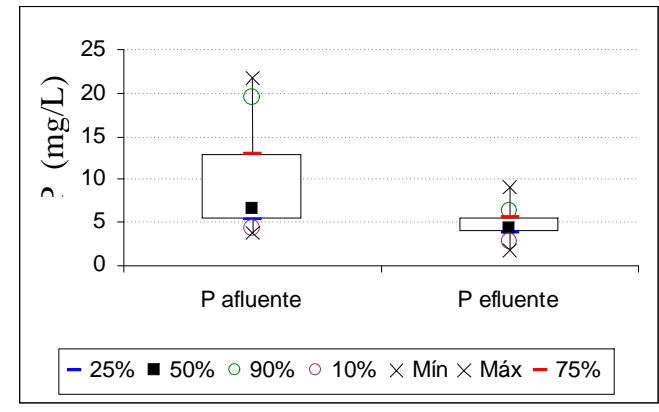

Figura 106: gráfico Box and Wiskers de $\mathrm{P}$ afluente e efluente.

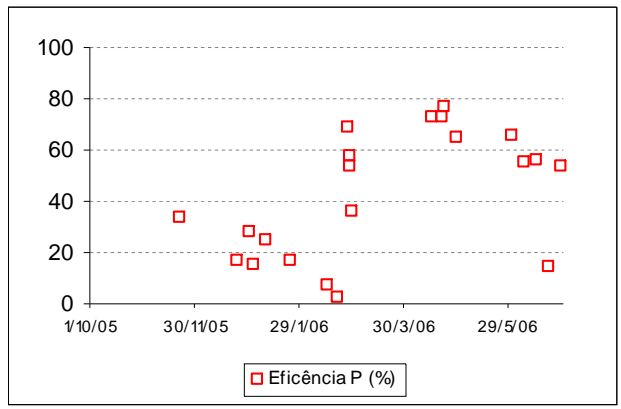

Figura 105: séries temporais da eficiência de remoção de $P$.

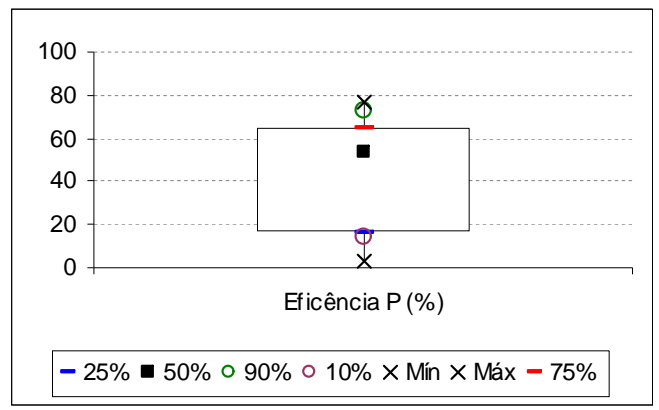

Figura 107: gráfico Box and Wiskers da eficiência de remoção de $P$. 


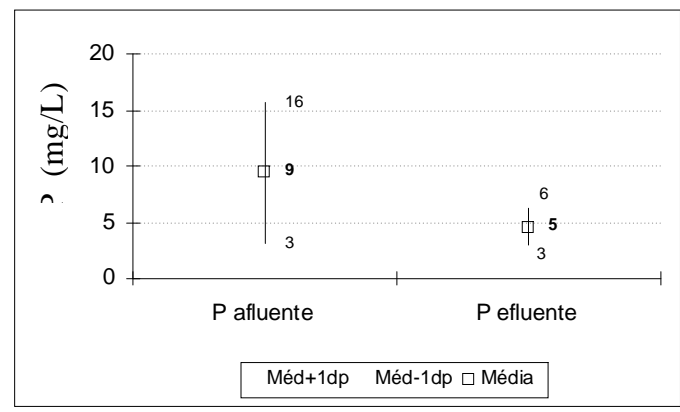

Figura 108: desvio padrão das séries temporais de $\mathrm{P}$ afluente e efluente.

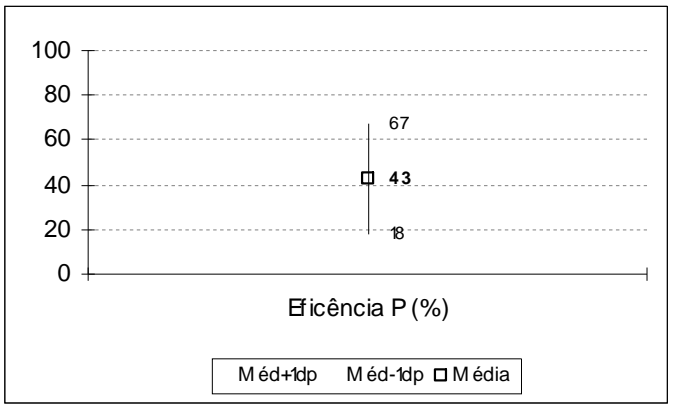

Figura 109: desvio padrão da eficiência de remoção de $P$.

As Figuras 104 a 109 apresentam valores de fósforo do esgoto estudado, onde se pode notar duas situações, uma em relação a sazonalidade e outra em relação a aplicação de cal hidratada. $\mathrm{Na}$ alta temporada e inicio da baixa temporada (março/2006), Pode-se observar um aumento da concentração de fósforo no afluente e efluente, provavelmente em função do aumento da população e conseqüente carga orgânica, em relação a eficiência, conforme Figura 105, nota-se uma remoção baixa do fósforo neste mesmo período (alta temporada), provavelmente em função da diminuição do tempo de detenção do sistema.

Pode-se observar, também, uma acentuada melhora conforme Figura 105, da eficiência a partir de fevereiro de 2006, data esta que se iniciou a aplicação de cal hidratada no Decantador de algas, como anteriormente citado, utilizava-se, somente polímero catiônico, e a partir desta data (fevereiro/2006) utiliza-se os dois, polímero catiônico (1 a 2,5 mg/L) seguido de cal hidratada com uma relação de 1:25 com o polímero, no caso, variando de $25 \mathrm{mg} / \mathrm{L}$ à $62,5 \mathrm{mg} / \mathrm{L}$, possivelmente, a cal hidratada aplicada colaborou com a remoção do fósforo promovendo a precipitação do ortofosfato no Decantador de algas. Apesar desta característica de remoção ser interessante, não se obteve resultados médios de concentração e eficiência tão significativos, como pode-se constatar nas Figuras 108 e 109, média de $9 \pm 6 \mathrm{mg} / \mathrm{L}$ no afluente, caracterizando-o como esgoto médio ( $8 \mathrm{mg} / \mathrm{L}$ - Tabela 1), com média de saída de $5 \pm 2 \mathrm{mg} / \mathrm{L}$ no efluente, a eficiência mostrou-se na ordem de $43 \pm 24 \%$. 


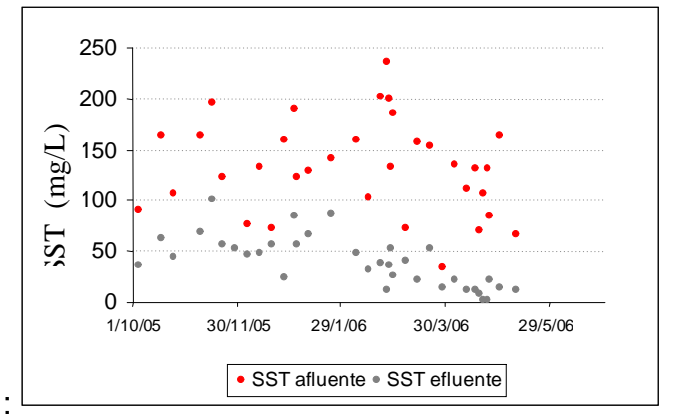

Figura 110: séries temporais de SST afluente e efluente.

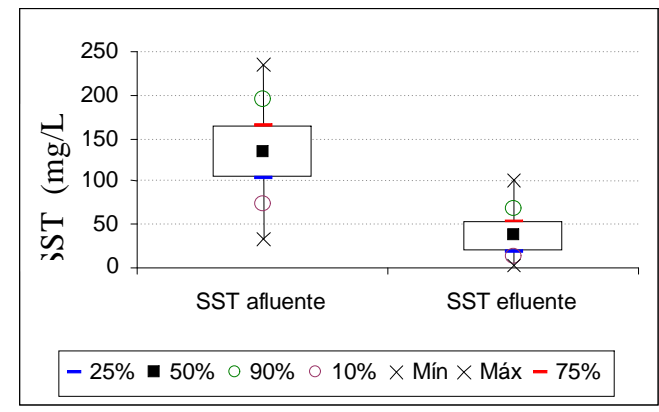

Figura 112: gráfico Box and Wiskers de SST afluente e efluente.

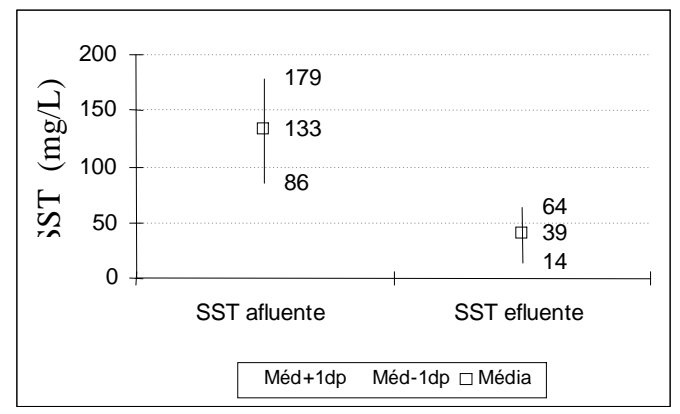

Figura 114: desvio padrão das séries temporais de SST afluente e efluente.

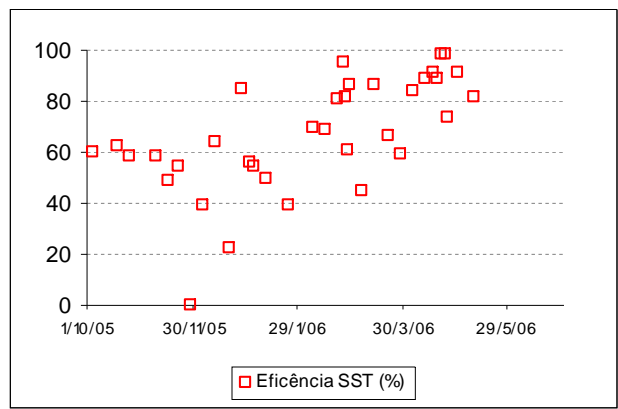

Figura 111: séries temporais da eficiência de remoção de SST.

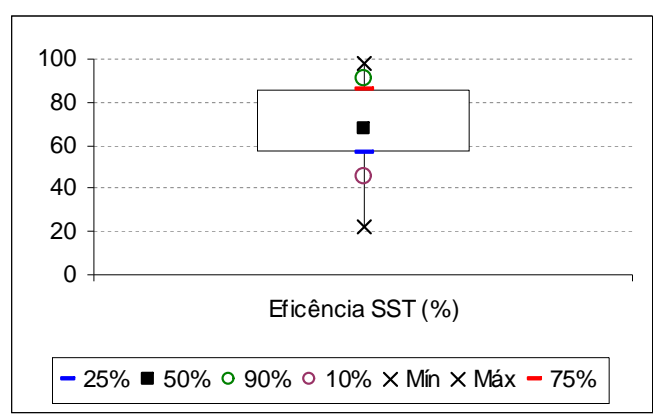

Figura 113: gráfico Box and Wiskers da eficiência de remoção de SST.

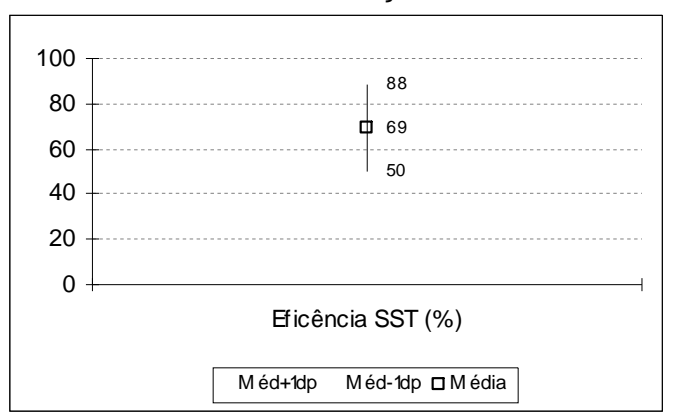

Figura 115: desvio padrão da eficiência de remoção de SST.

As Figuras 110 a 115 apresentam valores de SST do esgoto, onde se observa conforme a Figura 110 das séries temporais, que as concentrações no efluente diminuíram a partir da aplicação de cal hidratada (fevereiro/2006), a Figura 111, também aponta para resultados maiores de eficiência de remoção.

Os resultados conforme apontam para valores médios de SST no afluente de $133 \pm$ $47 \mathrm{mg} / \mathrm{L}$, caracterizando o esgoto como fraco para médio (médio $220 \mathrm{mg} / \mathrm{L}$ e fraco $100 \mathrm{mg} / \mathrm{L}$ - Tabela 3), e efluente com concentração média de $39 \pm 25 \mathrm{mg} / \mathrm{L}$. Pode-se observar nos gráficos Box and Wiskers e o desvio padrão em relação às eficiências do sistema que se obteve uma média de remoção de $69 \pm 19 \%$. Estes resultados atestam a boa eficiência do tratamento primário e também do Decantador de algas 
com aplicação de polímero e cal hidratada, que funciona no sistema coagulação/floculação, tendo um resultado de um efluente bastante clarificado.

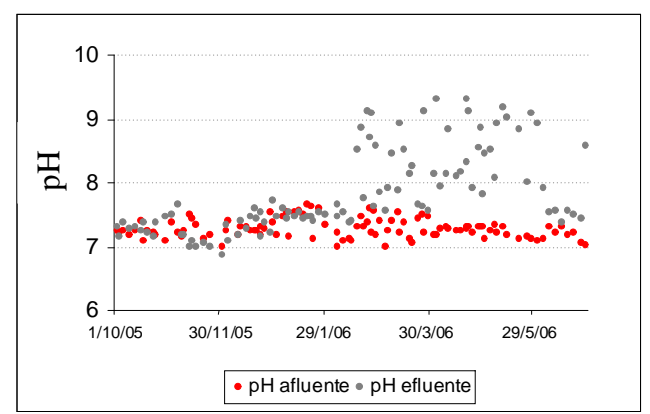

Figura 116: séries temporais de $\mathrm{pH}$ afluente e efluente.

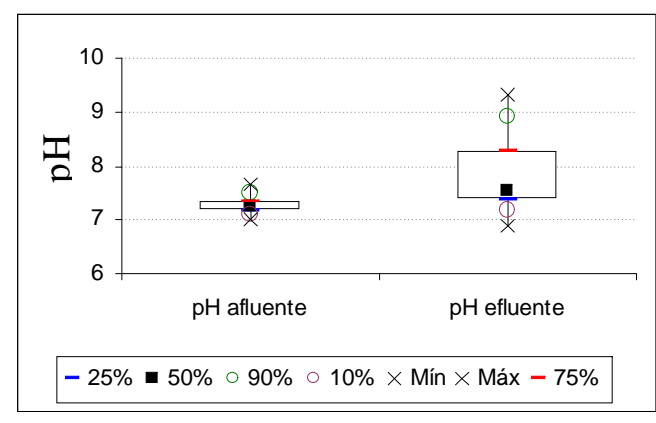

Figura 117: gráfico Box and Wiskers do $\mathrm{pH}$ afluente e efluente.

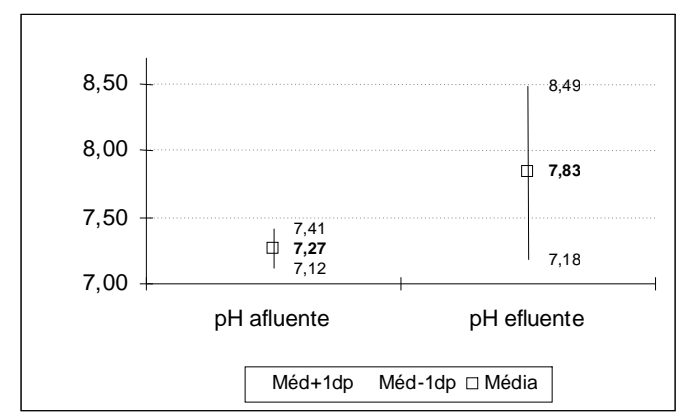

Figura 118: desvio padrão das séries temporais de $\mathrm{pH}$ afluente e efluente.

As Figuras 116 a 118, apresentam valores de $\mathrm{pH}$ do esgoto, onde se pode notar a variação do $\mathrm{pH}$ ao longo do período. Os resultados da série histórica apontam claramente a alteração do pH efluente a partir de fevereiro de 2006, tal fato é explicado devido ao inicio da aplicação de cal hidratada junto com o polímero no Decantador de algas. Obteve-se resultados médios, afluente 7,27 \pm 0,15 e efluente $7,83 \pm 0,65$, os resultados efluentes atestam a importância de um melhor controle do pH de saída, uma vez que a legislação estadual (decreto 8468/76) exige o pH entre 6,00 e 9,00 . 


\subsubsection{Avaliação quantitativa de clorofila-a e cianobactérias}

Nas Figuras 119 a 124, apresentam-se valores de clorofila-a afluente (saída da lagoa de maturação/entrada Decantador de algas) e efluente (saída do sistema) do esgoto estudado.

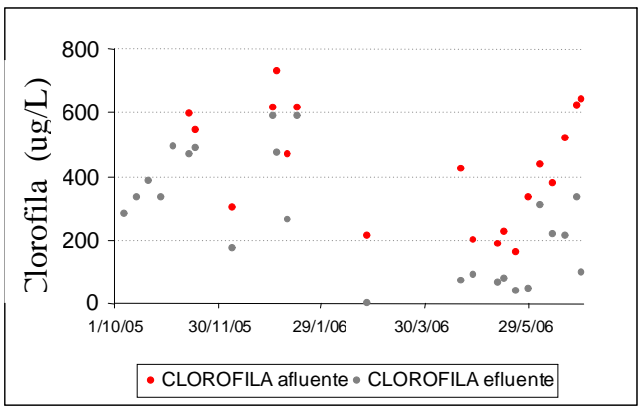

Figura 119: séries temporais de clorofila-a do Decantador de algas(afluente) e saída do sistema(efluente).

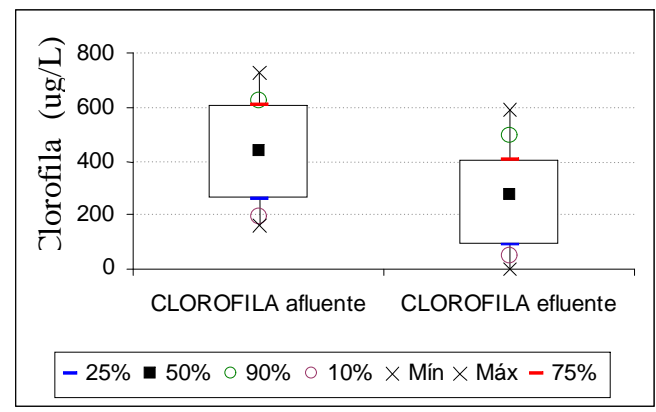

Figura 121: gráfico Box and Wiskers da clorofilaa do Decantador de algas(afluente) e saída do sistema(efluente).

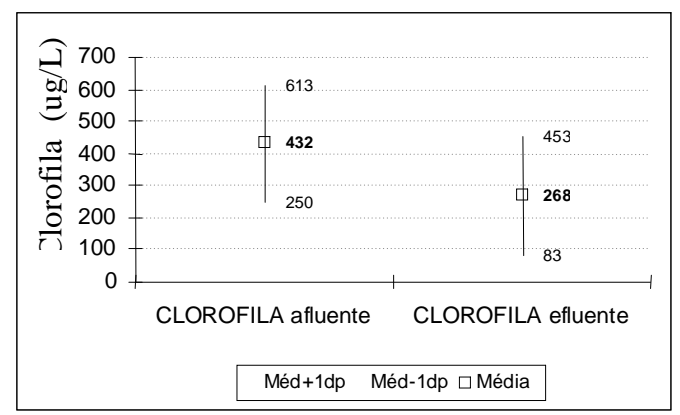

Figura 123: desvio padrão das séries temporais de clorofila-a do Decantador de algas(afluente) e saída do sistema(efluente).

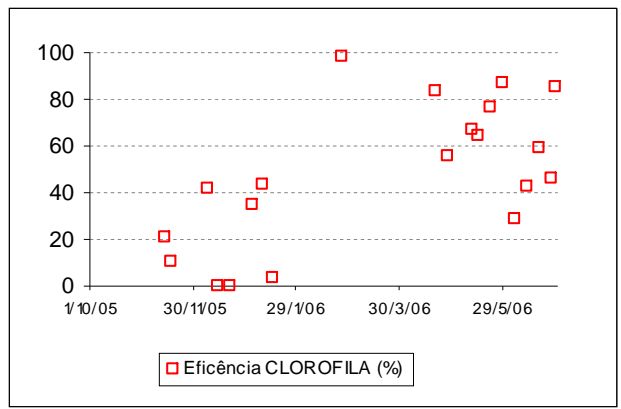

Figura 120: séries temporais da eficiência de remoção de clorofila-a do Decantador de algas(afluente) e saída do sistema(efluente).

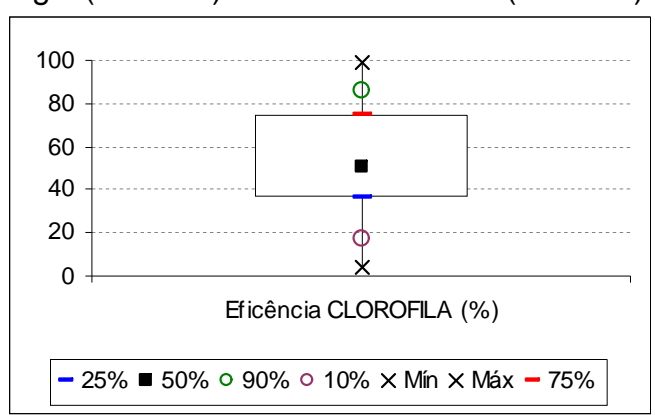

Figura 122: gráfico Box and Wiskers da eficiência de remoção de clorofila-a do Decantador de algas(afluente) e saída do sistema(efluente).

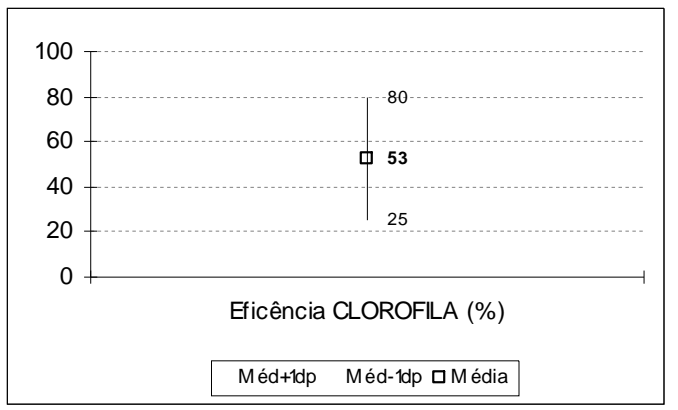

Figura 124: desvio padrão da eficiência de remoção de clorofila-a do Decantador de algas(afluente) e saída do sistema(efluente). 
Pode-se observar uma acentuada melhora conforme Figura 119, da eficiência na remoção de clorofila-a a partir de fevereiro de 2006, data esta que se iniciou a aplicação de cal hidratada no Decantador de algas, anteriormente utilizava-se, somente polímero catiônico, e a partir desta data (fevereiro/2006) utiliza-se os dois, polímero catiônico (1 a 2,5 mg/L) seguido de cal hidratada com uma relação de 1:25 com o polímero, no caso, variando de $25 \mathrm{mg} / \mathrm{L}$ à $62,5 \mathrm{mg} / \mathrm{L}$. Com a aplicação de cal melhorou-se a remoção de clorofila-a em função da remoção de sólidos suspensos.

Conforme Figuras 123 e 124, obteve-se média de $432 \pm 182 \mu \mathrm{g} / \mathrm{L}$ no afluente, com média de saída de $268 \pm 185 \mu \mathrm{g} / \mathrm{L}$ no efluente, a eficiência média mostrou-se na ordem de $53 \pm 28 \%$, porém, observando-se os resultados de eficiência somente após a aplicação de cal estes valores, conforme gráfico 120, apresentam significativa melhora. Estes resultados de clorofila-a para este sistema de tratamento de esgotos com as novas mudanças, ou seja, o sistema biológico precedido e sucedido por tratamento físico-químico, pode ser considerado satisfatório em termos de atendimento à legislação, pois, ao comparar-se os resultados de saída do sistema com os encontrados no corpo receptor, conforme a Tabela 17, estão aquém dos limites preconizados na Resolução CONAMA № 357/05 para rios classe II.

Observou-se também, que em abril/2006, não se aplicou cloro na saída do sistema, em função de reparo no equipamento, e obtiveram-se valores de clorofila-a baixos conforme Figura 119, de eficiência no efluente, ficando como sugestão par estudos futuros, a interferência da cloração na clorofila-a.

A Tabela 17 aponta que praticamente não há diferenças entre os resultados de jusante e montante, ou seja, não ocorreu impacto significativo sobre a qualidade da água do corpo receptor decorrente do lançamento deste efluente. 
Tabela 17: resultados de concentração de clorofila-a para os pontos a montante e jusante do lançamento do efluente tratado no corpo receptor ao longo do período estudado.

\section{MONTANTE $(\mu \mathrm{g} / \mathrm{L}) \quad$ JUSANTE $(\mu \mathrm{g} / \mathrm{L})$}

\begin{tabular}{ccc}
\hline máximo & 10,68 & 12,46 \\
mínimo & 0 & 0 \\
média & 2,94 & 3,06 \\
\hline
\end{tabular}

Nas Figuras 125 a 130, apresentam-se valores de cianobactérias afluentes (saída das lagoas facultativas) e efluentes (saída do sistema) do esgoto estudado.

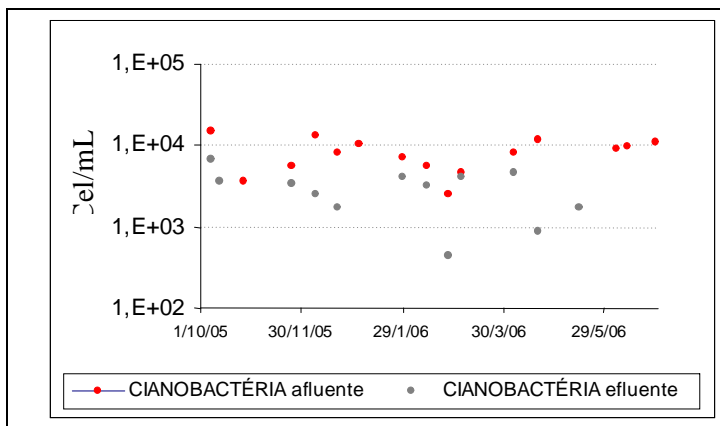

Figura 125: séries temporais de densidade de cianobactérias afluente e efluente.

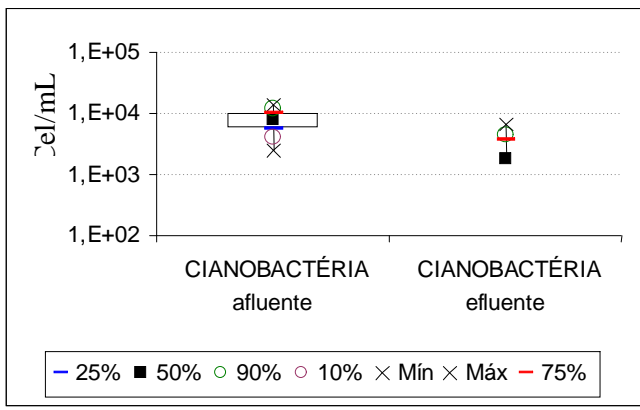

Figura 127: gráfico Box and Wiskers da densidade de cianobactérias afluente e efluente.

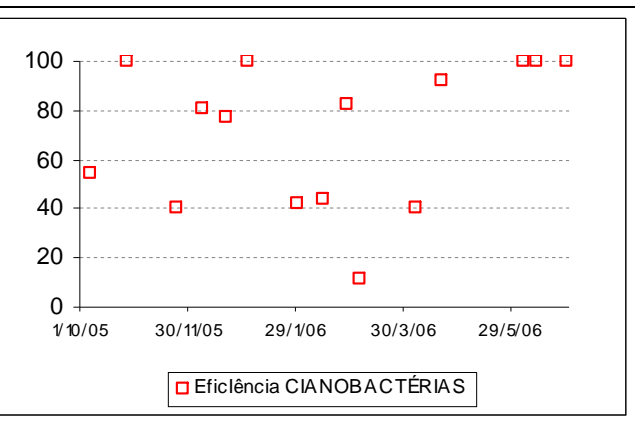

Figura 126: séries temporais da eficiência de remoção de cianobactérias.

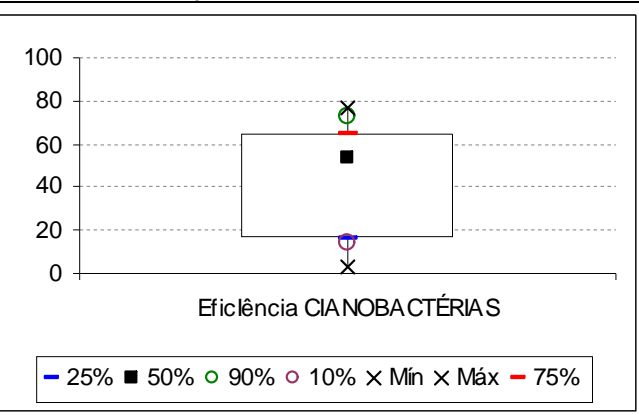

Figura 128: gráfico Box and Wiskers da eficiência de remoção de cianobactérias. 


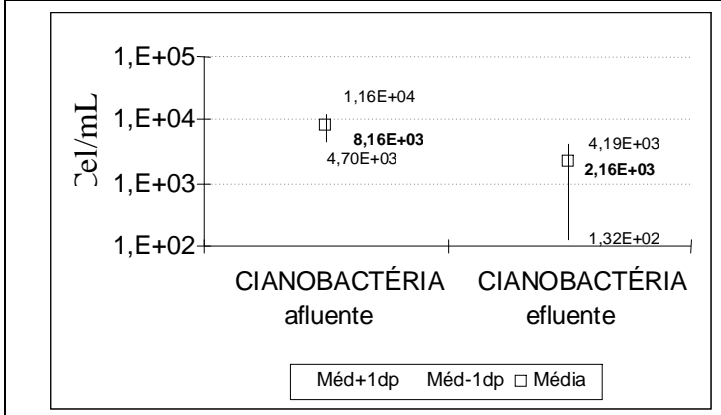

Figura 129: desvio padrão das séries temporais de cianobactérias afluente e efluente.

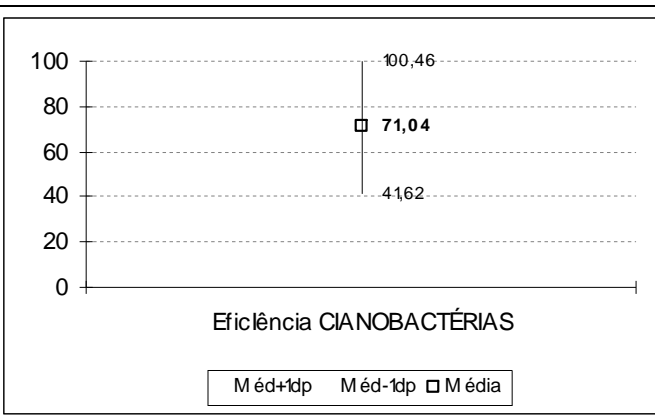

Figura 130: desvio padrão da eficiência de remoção de cianobactérias.

Pode-se observar aparentemente pouca variação na densidade de cianobactérias, conforme Figura 125 da série histórica. Obteve-se também, conforme Figura 126, uma eficiência menor na remoção de cianobactérias no período de alta temporada. Nas Figuras 129 e 130 pode-se observar que os valores de densidade de cianobactérias afluente apresentaram média $8160 \pm 3460 \mathrm{cel} / \mathrm{mL}$, densidade média de cianobactérias efluente foi $2160 \pm 2030 \mathrm{cel} / \mathrm{mL}$, a eficiência média mostrou-se na ordem de $71 \pm 29 \%$, podem-se enquadrar estes resultados do sistema de tratamento de esgotos com as novas mudanças, ou seja, o sistema biológico precedido e sucedido por tratamento físico-químico, como satisfatórios em termos de legislação, pois as densidades de cianobactérias encontradas foram inferiores aos limites da legislação CONAMA № 357/05 para rio classe I, II e III, onde temos limites de 20000 $\mathrm{cel} / \mathrm{ml}, 50000 \mathrm{cel} / \mathrm{ml}$ e $100000 \mathrm{cel} / \mathrm{mL}$, respectivamente.

\subsection{Inter-relações entre resultados}

A Tabela 18 apresenta os valores máximo, mínimo e médio das relações entre densidade de cianobactérias efluente e média das concentrações dos parâmetros de suporte e clorofila-a. 
Tabela 18: média, máxima e mínima das relações entre densidade de cianobactérias efluente e média das concentrações dos parâmetros de suporte e clorofila-a.

\begin{tabular}{ccccccc}
\hline & CIA:DBO & CIA:DQO & CIA:N & CIA:P & CIA:SST & CIA:CLOROFILA \\
\hline MÉDIA & 89,1 & 25,3 & 141,0 & 671,3 & 78,6 & 18,0 \\
MÁXIMO & 191,6 & 54,4 & 303,3 & 1444,1 & 169,1 & 23,5 \\
MÍNIMO & 12,8 & 3,6 & 20,2 & 96,3 & 11,3 & 12,2 \\
\hline
\end{tabular}

A Tabela 19 apresenta os valores máximo, mínimo e médio das relações entre concentração de clorofila-a efluente e média das concentrações dos parâmetros de suporte.

Tabela 19: média, máxima e mínima das relações entre as concentrações de clorofila-a efluente e média das concentrações dos parâmetros de suporte.

\begin{tabular}{lccccc}
\hline \multicolumn{7}{c}{ CLOROFILA:DBO } & CLOROFILA:DQO & CLOROFILA:N & CLOROFILA:P & CLOROFILA:SST \\
\hline MÉDIA & 7,8 & 2,3 & 12,4 & 58,8 & 6,9 \\
MÁXIMO & 17,2 & 4,9 & 27,2 & 129,7 & 15,2 \\
MíNIMO & 0,1 & 0,3 & 0,1 & 0,7 & 0,1 \\
\hline
\end{tabular}

As Figuras 131, 132, 133, 134 e 135 apresentam o comportamento ao longo do período estudado de todos os parâmetros, tanto de controle quanto de suporte. No eixo à esquerda encontram-se as concentrações de clorofila-a e densidade de cianobactérias efluentes, enquanto que no eixo à direita constam as concentrações de DBO, DQO, N, P e SST, respectivamente.

Como pode ser observada nas Figura 131 a relação média entre os parâmetros considerados de controle cianobactéria:clorofila-a (linha preta e azul, respectivamente) foi de 18,0, onde a relação máxima é 23,5 e a mínima 12,2. Podese observar na Figura 131, que a curvas se acompanham com uma certa coerência 
entre os dois parâmetros, apesar de alguns picos de diferença, como no período de abril, onde a cianobactéria aumentou e a concentração de clorofila-a diminuiu, vale lembrar o citado em relação a clorofila-a no mês de abril, não houve cloração.

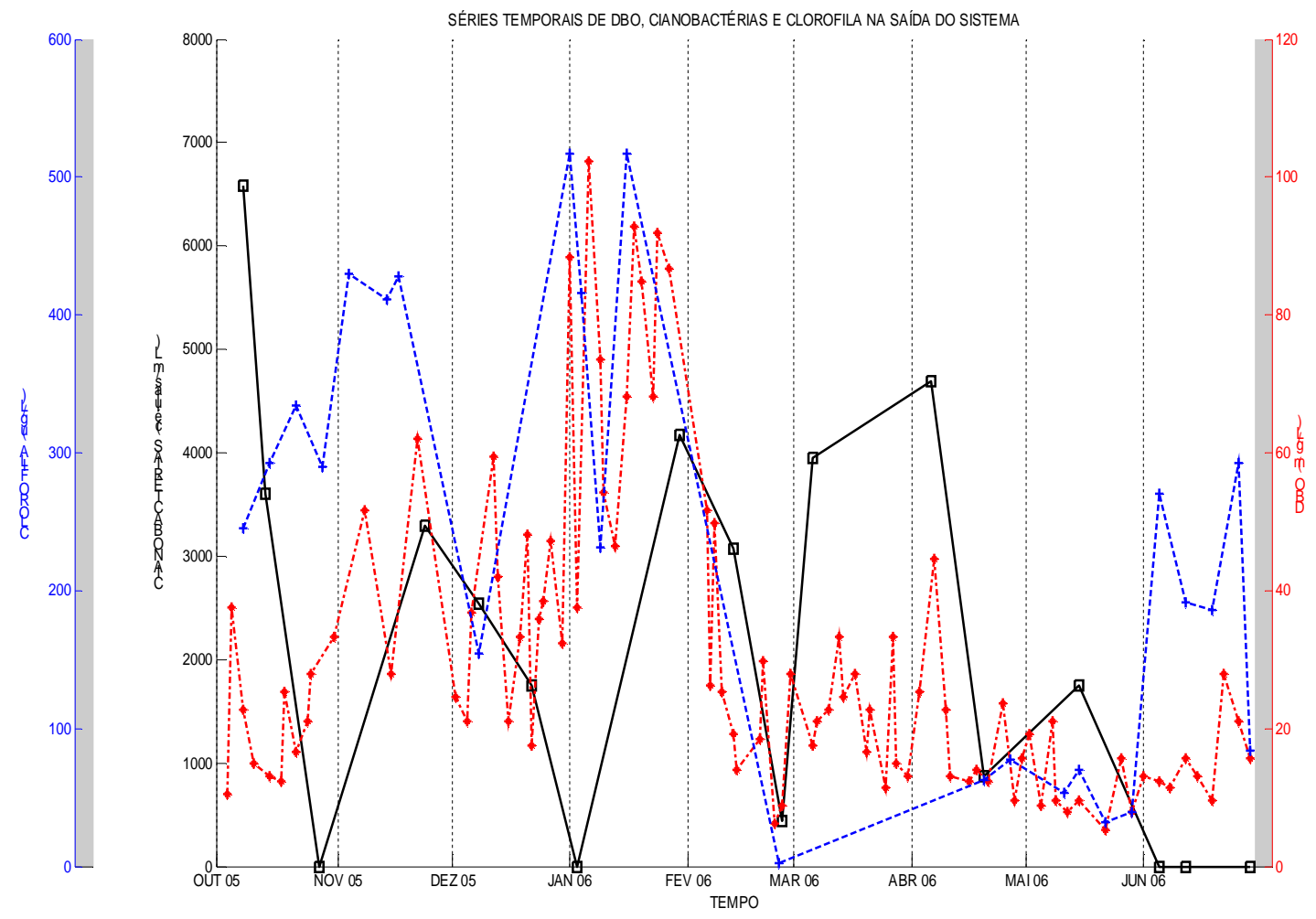

Figura 131: séries temporais de DBO, densidade de cianobactérias e clorofila-a na saída do sistema.

Analisando a Figura 131 verifica-se que aparentemente há um padrão bem definido entre as curvas dos parâmetros densidade de cianobactérias, DBO e clorofila-a na saída do sistema, onde as curvas se acompanham nos picos, tanto na lata como na baixa temporada, com exceção de abril/2006 para clorofila-a. Conforme a Tabela 18, a relação média entre os parâmetros cianobactéria:DBO foi de 89,1 , onde a relação máxima é 191,6 e mínima de 12,8. Pode-se observar também que a relação entre clorofila-a:DBO foi de 7,8, a máxima é 17,2 e a mínima de 0,1. 


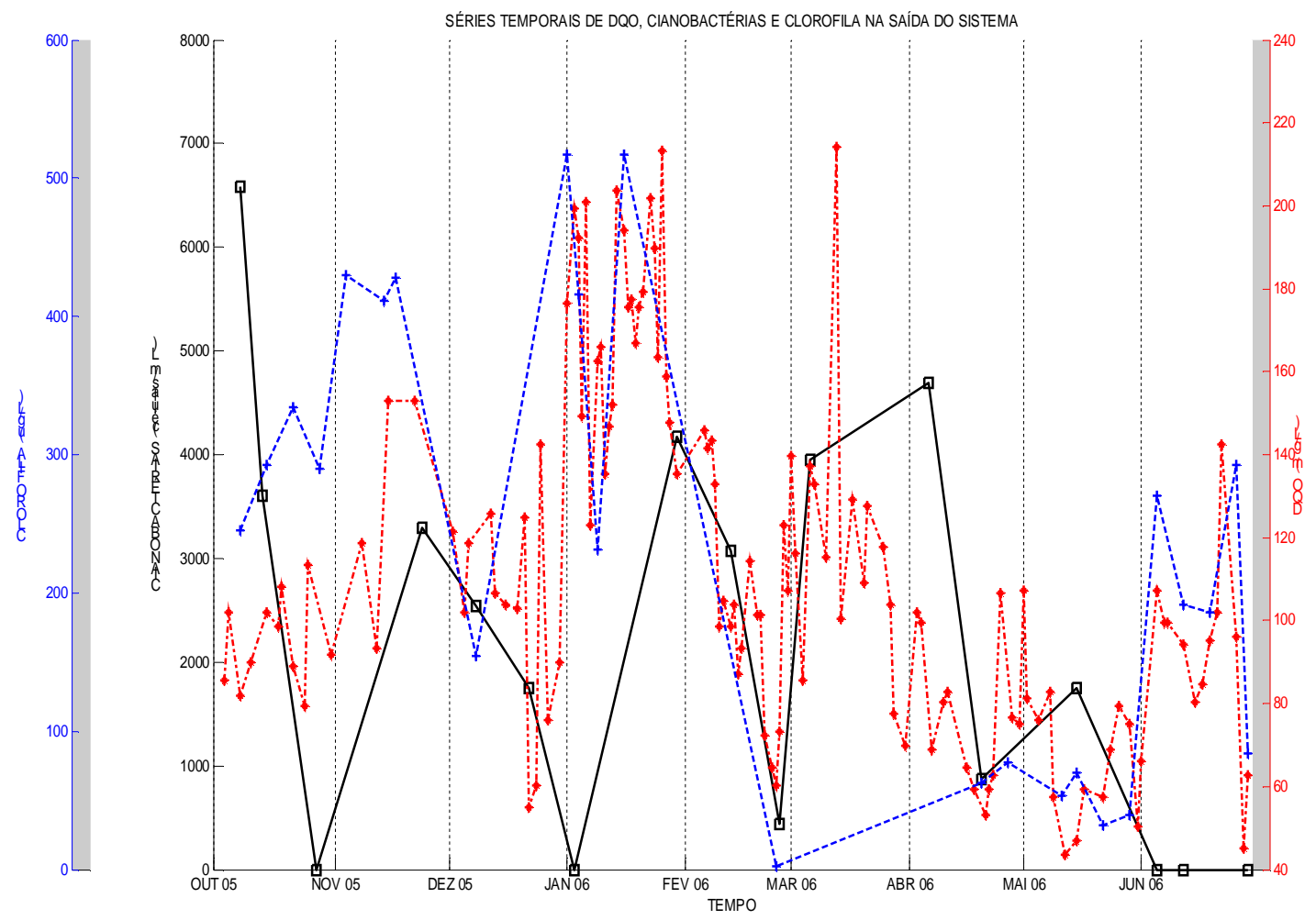

Figura 132: séries temporais de DQO, densidade de cianobactérias e clorofila-a na saída do sistema.

Na Figura 132, como ocorrido na Figura 130, pode-se observar um comportamento da curva com padrão definido, onde os picos dos três parâmetros para cima e para baixo acompanharam-se à exceção da clorofila-a no mês de abril/2006. A relação média entre os parâmetros cianobactéria:DQO foi de 25,3 , a relação máxima é 54,4 e mínima de 3,6. Pode-se observar também que a relação entre clorofila-a:DQO foi de 2,3, a relação máxima 4,9 e a mínima de 0,3. 


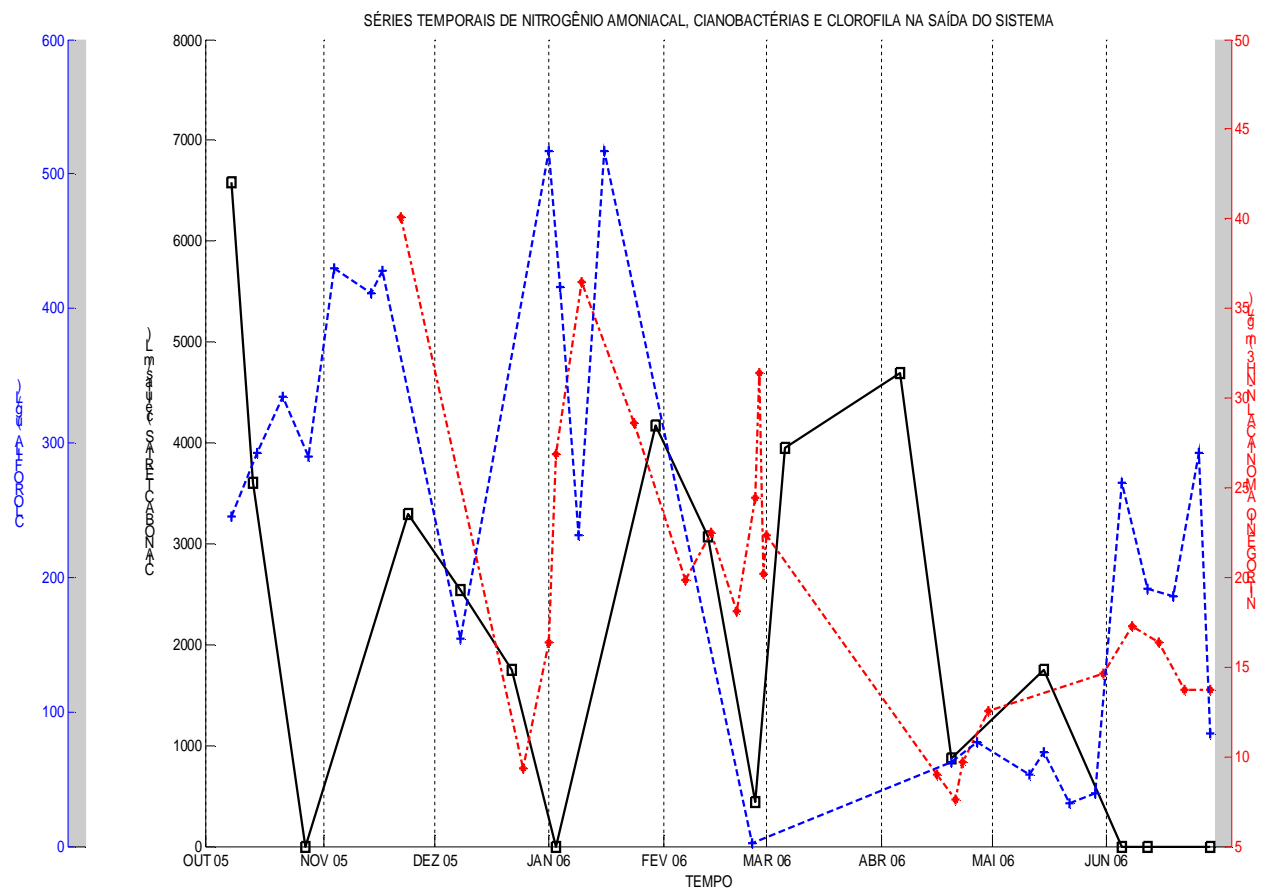

Figura 133: séries temporais de $\mathrm{N}-\mathrm{NH}_{3}$, densidade de cianobactérias e clorofila-a na saída do sistema.

A Figura 133 relativa ao parâmetro nitrogênio amoniacal, não demonstra um comportamento bem definido, uma vez que a quantidade de dados de nitrogênio amoniacal é pequena em relação aos parâmetros de controle (anexo A), porém, alguns picos na alta temporada e baixa também, tiveram alguma coerência, afinal, as características do esgoto estudado são bem definidas (esgoto doméstico de médio para fraco), com eficiências de remoção consideradas adequadas, com isso, obteve-se até aqui, para todos os parâmetros, curvas com comportamentos parecidos. A relação média entre os parâmetros cianobactéria:nitrogênio amoniacal foi de 141,0, a relação máxima 303,3 e mínima de 20,2. Pode-se observar também que a relação entre clorofila-a:nitrogênio amoniacal foi de 12,4 a relação máxima é 27,2 e mínima de 0,1 . 


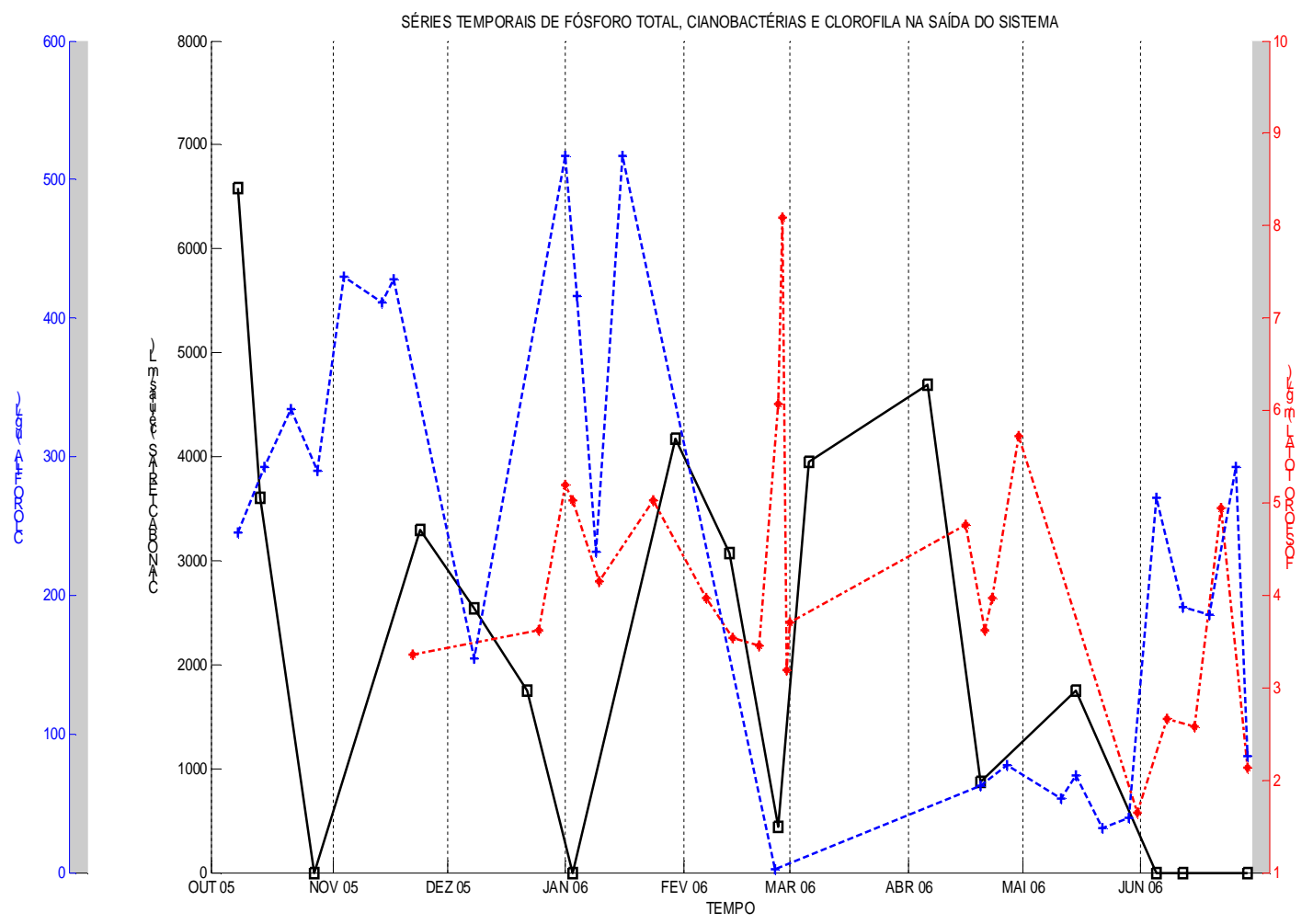

Figura 134: séries temporais de $\mathrm{P}$, densidade de cianobactérias e clorofila-a na saída do sistema.

A Figura 134 para o parâmetro fósforo, assim como o nitrogênio, não demonstra um comportamento bem definido, uma vez que a quantidade de dados de fósforo é pequena em relação aos parâmetros de controle (anexo A), porém, alguns picos na alta temporada (janeiro e fevereiro) e baixa temporada (Junho), tiveram alguma coerência. A relação média entre os parâmetros cianobactéria: foi de 671,3 a relação máxima 1444,1 e mínima de 96,3. Pode-se observar também que a relação entre clorofila-a:fósforo foi de 58,8, a relação máxima é 129,7 e mínima de 15,2. 


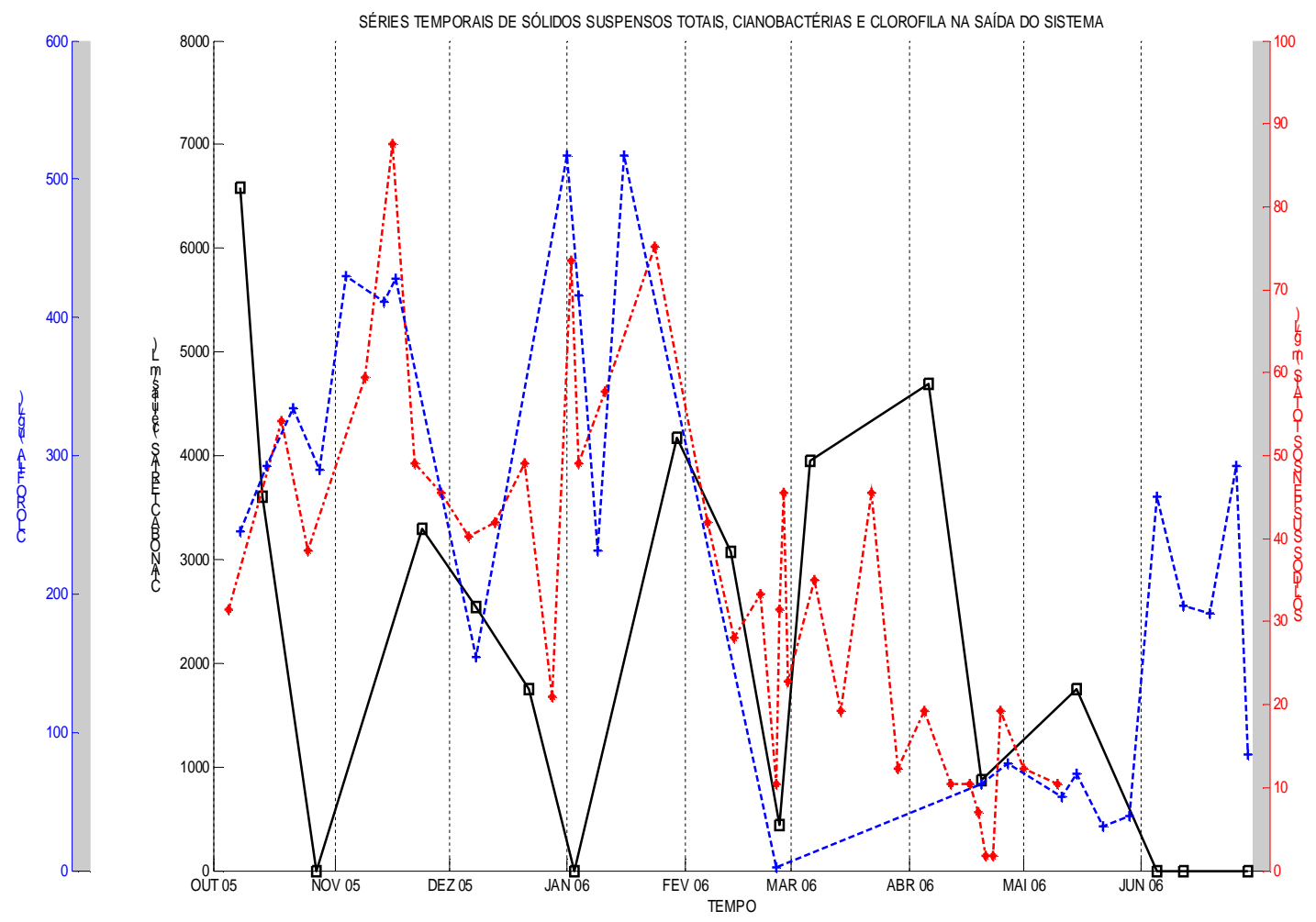

Figura 135: séries temporais de SST, densidade de cianobactérias e clorofila-a na saída do sistema.

Na Figura 135 é possível verificar um padrão de comportamento bem definido entre SST e clorofila-a e cianobactéria ao longo de toda a série, obteve-se uma curva de SST que acompanhou todos os picos, tanto na alta temporada como na baixa, com exceção do mês de abril/2006. A relação média entre os parâmetros cianobactéria:SST foi de 78,6, a relação máxima 169,1 e mínima de 11,3. Pode-se observar também que a relação entre clorofila-a:SST foi de 6,9, a relação máxima 15,2 e mínima de 0,1 . 


\section{CONCLUSÕES}

A presente pesquisa permitiu concluir que:

- Em relação as cianobactérias no sistema estudado, foram encontradas ao longo do sistema (lagos faculativas, lagoa de maturação e Decantador de algas) as seguintes espécies de cianobactérias: Planktothrix $s p$, Merismopedia sp, Microcystis $s p$, Phormidium sp, Chroococcus $s p$, Pseudonabaena sp, Aphanocapsa sp.

- Ao longo de todo o período de estudo, as espécies mais presentes foram, Planktothrix sp.(90 a 100\%) e a Merismopedia sp.(5 a 67\%), demonstrando assim, que as duas espécies são claramente predominantes no sistema estudado. Pode-se observar também, que a Planktothrix sp, tanto na baixa temporada como na alta temporada, possui a maior capacidade de permanecer no sistema com melhor resistência a remoção, seguida pela Merismopedia sp, tanto na parte biológica como na parte físico-química, e que todas as outras espécies são removidas até o Decantador de algas.

- Foram estes os valores encontrados ao longo do sistema para densidades de cianobactérias na baixa temporada para lagoas facultativas - $18880 \mathrm{cel} / \mathrm{mL}$; lagoa de maturação - $16350 \mathrm{cel} / \mathrm{mL}$; Decantador de algas - $4680 \mathrm{cel} / \mathrm{mL}$; saída do sistema - $6400 \mathrm{cel} / \mathrm{mL}$; e na alta temporada para lagoas facultativas - $26340 \mathrm{cel} / \mathrm{mL}$; lagoa de maturação - $13170 \mathrm{cel} / \mathrm{mL}$; Decantador de algas $11840 \mathrm{cel} / \mathrm{mL}$; saída do sistema - $2910 \mathrm{cel} / \mathrm{mL}$. As densidades de cianobactérias encontradas na baixa e alta temporada na saída do tratamento refletem valores sempre positivos em relação à nova legislação CONAMA № 357/05 no que tange o limite de cianobactérias no despejo águas classe I, II e III.

- Para os parâmetros convencionais analisados (parâmetros de suporte), o sistema de tratamento de esgotos estudado se mostrou eficiente em termos 
de legislação (decreto 8468/76 - CETESB) ao longo do período, onde se obtiveram porcentagem de atendimento aos padrões ao longo do período de $86,7 \%, 74,6 \%, 36,4 \%, 45,5 \%, 100 \%, 91,3 \%$, para os parâmetros de DBO, $\mathrm{DQO}$, nitrogênio amoniacal, fósforo, SST e pH, respectivamente.

- Para os parâmetros de suporte nitrogênio amoniacal e fósforo, o sistema, assim como outros tradicionais (lagoas de estabilização, lodos ativados, etc), não se mostrou como a melhor solução, com eficiências de remoção apenas razoáveis.

- Em relação ao pH do efluente, o mesmo tornou-se alcalino, onde os resultados apontam para uma média no efluente de 8,00, mínima de 6,87 e máxima de 9,30. Tala fato deve-se ao inicio da aplicação de cal hidratada como coadjuvante na coagulação/floculação junto com o polímero no Decantador de algas. Estes resultados atestam a importância de um melhor controle do pH de saída, pois a legislação Estadual (CETESB 8468/76) coloca como limite o pH entre 6 a 9.

- Com a quantidade de dados gerada para este sistema ao longo do estudo, foi possível observar uma relação entre os parâmetros de suporte e os parâmetros de controle, CIA:DBO - 89,1; CIA:DQO - 25,3; CIA:N - 141,0; CIA:P - 671,3; CIA:SST - 78,6; CIA:CLOROFILA - 18,0; CLOROFILA:DBO 7,8; CLOROFILA:DQO - 2,3; CLOROFILA:N - 12,4; CLOROFILA:P - 58,8; CLOROFILA:SST - 6,9.

- Concentrações de clorofila-a afluentes (saída da lagoa de maturação) e efluentes (saída do sistema-despejo), sofrem pequena variação ao longo do período estudado em função da sazonalidade do sistema, onde nos meses de baixa temporada a clorofila-a é um pouco menor em relação aos meses da alta temporada. 
- Com a aplicação de cal melhorou-se a remoção de clorofila-a em função da remoção de sólidos suspensos.

- Os valores de clorofila-a afluente (saída da lagoa de maturação) ficaram com uma média de $432 \pm 182 \mu \mathrm{g} / \mathrm{L}$, com média de saída de $268 \pm 185 \mu \mathrm{g} / \mathrm{L}$ no efluente (saída do sistema), a eficiência média mostrou-se na ordem de $53 \pm$ $28 \%$, estes resultados de clorofila-a para este sistema de tratamento de esgotos com as novas mudanças, ou seja, o sistema biológico precedido e sucedido por tratamento físico-químico, pode ser considerado satisfatório em termos de atendimento à legislação, pois, ao comparar-se os resultados de saída do sistema com os encontrados no corpo receptor, estão aquém dos limites preconizados na Resolução CONAMA № 357/05 para águas classe I, II e III. 


\section{SUGESTÕES PARA FUTURAS PESQUISAS}

Para futuras pesquisas visando à avaliação da presença de cianobactérias em sistemas de tratamento biológicos e físico-químicos, recomenda-se:

- Determinar a influência ou não das toxicinas liberadas pelas cianobactérias no efluente final, através de ensaios de toxicidade crônica e aguda com Dhaphinias e Ceriodaphinias.

- Determinar com base nos resultados das análises, os graus de diluição necessários para permitir o atendimento a CONAMA № 357/05.

- Dar continuidade ao levantamento de dados para se criar relações entre os parâmetros de suporte e controle, ainda mais confiáveis.

- Estudar a influência da desinfecção por cloração na clorofila-a.

- Dar continuidade aos estudos da ocorrência de cianobactérias em sistemas de lagoas. 


\section{REFERÊNCIAS BIBLIOGRÁFICAS}

- Agujaro L.F., et al. 2006. Manual ilustrado para identificação e contagem de cianobactérias plantctônicas de águas continentais Brasileiras. Rio de Janeiro. Interciência. 53p.

- Azevedo S.M.F.O. 1998. Toxinas de Cianobactérias: Causas e conseqüências para a Saúde Pública. Medicina On line - Revista Virtual de Medicina - Volume 1- Número 3 - Ano I (Jul/Ago/Set de 1998).

- Bassoi, L.J. et al. 1990. Implementação de testes de toxicidade no controle de efluentes líquidos. CETESB. 7p. /Série Manuais/

- Bicudo, C.E.M., Menezes, M., 2005. Gêneros de algas de águas continentais do Brasil - chave para identificação e descrições. São Carlos - SP. Ed.Rima. 508p.

- Reviers,B.,2006. Biologia e Filogenia das algas. Porto Alegre - RS. Ed. Artmed. $208 p$.

- Bitencourt, M.C., Oliveira, M.C. \&Yunes, J.S. 2001. Cianobactérias tóxicas. Revista Biotecnologia ano IV número 23, novembro/dezembro de 2001 pgs: 44 a 47, UNESP/USP/FURG.

- BRASIL, Ministério do Meio Ambiente. Conselho Nacional do Meio Ambiente. Resolução no 357 de 17 de Março de 2005. Dispõe sobre a classificação dos corpos de água e diretrizes Ambientais para o seu enquadramento, bem como estabelece as condições e padrões de lançamento de efluentes, e dá outras providências. Diário Oficial da União, 18 mar.2005.

- BRASIL, Ministério da Saúde. Portaria MS no 518 de 25 de Março de 2004. Estabelece os procedimentos e responsabilidades relativos ao controle e vigilância da qualidade da água para consumo humano e seu padrão de potabilidade, e dá outras providências. 25 Mar.2004. 
- CETESB, Norma Técnica L5.313 - Coleta de Fitoplâncton Marinho e de água doce: Procedimento, Junho/91.

- CETESB, Norma Técnica L5.303 - Determinação de Fitoplâncton de água doce Métodos qualitativo e quantitativo: método de ensaio, Junho/91.

- CETESB, Norma Técnica L5.321 - Água - Determinação do Potencial de crescimento algáceo: método de ensaio, Dez/89.

- CETESB, Norma Técnica L5.721- Método Colorimétrico para Demanda Química de Oxigênio, 1995.

- CETESB, Norma Técnica L5.306 - Determinação de Pigmentos Fotossintetizantes, Clorofila-a, b, c e Feofitina-a, 1990.

- - Chernicharo, C.A., 1997. Reatores Anaeróbios. UFMG. 414p.

-- Di Bernardo, L. 1995. Algas e suas influências na qualidade das águas e nas Tecnologias de Tratamento. Rio de Janeiro. ABES. 140p.

- Eaton, A.D.; Clesceri, L.S. \& Greenberg, A.E. (Eds.). 1995. Standard Methods for the Examination of Water and Wastewater. 19a Ed. APHA/AWWA/WEF.

- Gherardi-Goldstein, E. et al. 1990. Procedimentos para utilização de testes de toxicidade no controle de efluentes líquidos. CETESB. 17p. /Série Manuais/

- Jordão, E.P. \& Pessoa, C.A. 2005. Tratamento de Esgotos Domésticos. 4a Ed.

- Mara, D. D. \& Pearson, H. W. 1998. Design manual for waste stabilization ponds in Mediterranean Countries. Leeds, Inglaterra. Publ.: Lagoon Technology International. 112 p. + XIV. Livro disponível na íntegra na Internet: www.leeds.ac.uk/civil/ceri/water/tphe/publicat/pdm/med/procwsp.pdf 
- Metcalf \& Eddy. 1991. Wastewater Enginneering. Treatment, Disposal and Reuse. 3a Ed.

- Monteggia, L.O. e Tessele, F. 2001. Remoção físico-química de algas e fósforo de efluentes de lagoas de alta taxa. Pós-tratamento de efluentes de reatores anaeróbios: coletânea de trabalhos técnicos vol.2 - PROSAB - Belo Horizonte -MG., 2001. Pág. 97 - 102.

- Monteggia, L.O. e Zancan Filho L.C. 2001. Remoção de algas de lagoas de alta taxa por filtração biológica para pós-tratamento de reatores anaeróbios. Póstratamento de efluentes de reatores anaeróbios: coletânea de trabalhos técnicos vol.2 - PROSAB - Belo Horizonte -MG., 2001. Pág. 103 - 110.

- Olive,N. 2002. Design of a Chemically Enhanced Primary Treatment Plant for the City of Alfenas, Minas, Gerais, Brazil.Submitted to the Department of Civil and Environmental Engineering in Partial Fulfillment of the Requirements for the Degree of Master of Engineering in Civil and Environmental Engineering at the Massachusetts Institute of Technology.

- Paschoal, C.M.R.B.; Masutti, M.B.; Oliveira Neto, A..L. \& Espíndola, E.L.G. 2004. Avaliação e Adequação do Laboratório de Controle Ambiental da Riviera de São Lourenço. Relatório Final. São Carlos. Laboratório de Ecofisiologia e Ecotoxicologia Aquática, CRHEA-EESC-USP. Setembro 2004.

- Pimentel,J.S. Tratamento físico-químico de esgotos e reuso de efluente - cada idéia tem seu tempo. Superintendência de Desenvolvimento Tecnológico - TD

- Pivelli, R.P. 2003. Apostila de Tratamento de Esgotos Sanitários. São Paulo. USP - Faculdade de Saúde Pública. Curso de Especialização em Engenharia e Controle da Poluição Ambiental.

- SÃO PAULO(Estado). Decreto №8468 de Setembro 1976. Aprova o regulamento da Lei no997 de 31de maio de 1976, que dispõe sobre a prevenção e o controle da 
poluição do meio ambiente.Legislação estadual: controle de poluição ambiental,: São Paulo, CETESB,1991.

- Sobrinho, P.A \& Tomoyuki, M. 1999. Coleta e transporte de esgoto sanitário. São Paulo. 547p.

- Von Sperling, M. 1996. Lagoas de Estabilização. Belo Horizonte. UFMG. 134 p.

- Von Sperling, M. 1997. Princípios básicos de tratamento de esgotos. Belo Horizonte. UFMG. 211p.

- Von Sperling, M. 1996. Introdução à qualidade das águas e ao tratamento de esgotos. Belo Horizonte. UFMG. 243p.

- Yunes, J.S.; et al. 2003. Estudo da migração vertical diária das cianobactérias na represa do Irai e a avaliação das cianotoxicinas. IV Seminário do Projeto Interdisciplinar sobre Eutrofização de Águas de Abastecimento Público na Bacia do Altíssimo Iguaçu, Curitiba-PR, 18 e 19 de novembro de 2003.

- Zagatto, P.A, et al, 1997. Manual de orientação em casos de florações de alga tóxicas: um problema ambiental e de saúde pública. São Paulo. CETESB. 


\section{ANEXO A - Resultados da análise estatística das concentrações para entrada e saída do sistema}

\begin{tabular}{|c|c|c|c|c|c|c|c|c|c|c|c|c|c|c|c|c|}
\hline \multirow[t]{2}{*}{ Estatística } & \multicolumn{2}{|c|}{ DBO } & \multicolumn{2}{|c|}{ DQO } & \multicolumn{2}{|c|}{$\mathbf{N}$} & \multicolumn{2}{|c|}{$\mathbf{P}$} & \multicolumn{2}{|c|}{ SST } & \multicolumn{2}{|c|}{ CLOROFILA } & \multicolumn{2}{|c|}{$\mathrm{pH}$} & \multicolumn{2}{|c|}{ CIANOBACTÉRIAS } \\
\hline & Afluente & Efluente & Afluente & Efluente & Afluente & Efluente & Afluente & Efluente & Afluente & Efluente & Afluente & Efluente & Afluente & Efluente & Afluente & Efluente \\
\hline Núm dados & 90 & 90 & 126 & 126 & 22 & 22 & 22 & 22 & 34 & 35 & 37 & 42 & 104 & 104 & 20 & 20 \\
\hline Média & 160 & 34 & 371 & 121 & 45 & 27 & 9 & 5 & 133 & 39 & 314 & 293 & 7 & 8 & $1,5 \mathrm{E}+04$ & $6,4 \mathrm{E}+03$ \\
\hline Mínimo & 12 & 6 & 82 & 44 & 20 & 10 & 3,9 & 1,74 & 34 & 2 & 48,06 & 2,67 & 6,99 & 6,87 & $1,7 \mathrm{E}+03$ & $0,0 \mathrm{E}+00$ \\
\hline Máximo & 381 & 117 & 751 & 239 & 70 & 53 & 21,6 & 9,1 & 236 & 100 & 731,58 & 591,21 & 7,64 & 9,3 & $6,6 \mathrm{E}+04$ & $3,8 \mathrm{E}+04$ \\
\hline Média & 160 & 34 & 371 & 121 & 45 & 27 & 9 & 5 & 133 & 39 & 314 & 293 & 7 & 8 & $1,5 \mathrm{E}+04$ & $6,4 \mathrm{E}+03$ \\
\hline Desvio padrão & 81 & 26 & 147 & 47 & 14 & 12 & 6 & 2 & 47 & 25 & 193 & 158 & 0 & 1 & $1,5 \mathrm{E}+04$ & $8,3 \mathrm{E}+03$ \\
\hline Méd - 1 desvpad & 79 & 9 & 224 & 74 & 31 & 15 & 3 & 3 & 86 & 14 & 121 & 135 & 7 & 7 & $-8,6 \mathrm{E}+01$ & $-1,9 \mathrm{E}+03$ \\
\hline Méd + 1 desvpad & 242 & 60 & 518 & 168 & 58 & 39 & 16 & 6 & 179 & 64 & 507 & 452 & 7 & 8 & $2,9 \mathrm{E}+04$ & $1,5 \mathrm{E}+04$ \\
\hline $10 \%$ & 69 & 11 & 187 & 65 & 28 & 12 & 4 & 3 & 72 & 12 & 89 & 73 & 7 & 7 & $3,2 \mathrm{E}+03$ & $8,3 \mathrm{E}+02$ \\
\hline $25 \%$ & 109 & 16 & 280 & 86 & 34 & 17 & 5 & 4 & 103 & 18 & 160 & 185 & 7 & 7 & $4,6 \mathrm{E}+03$ & $2,3 \mathrm{E}+03$ \\
\hline $50 \%$ & 138 & 26 & 349 & 111 & 48 & 27 & 6 & 4 & 133 & 38 & 312 & 306 & 7 & 8 & $1,1 \mathrm{E}+04$ & $4,1 \mathrm{E}+03$ \\
\hline $75 \%$ & 212 & 43 & 484 & 151 & 53 & 35 & 13 & 6 & 163 & 54 & 435 & 379 & 7 & 8 & $1,6 \mathrm{E}+04$ & $6,7 \mathrm{E}+03$ \\
\hline $90 \%$ & 273 & 72 & 593 & 195 & 62 & 43 & 20 & 6 & 194 & 67 & 601 & 491 & 7 & 9 & $2,6 \mathrm{E}+04$ & $9,5 \mathrm{E}+03$ \\
\hline
\end{tabular}




\section{ANEXO B - Resultados da análise estatística das eficiências}

\begin{tabular}{|l|c|c|c|c|c|c|c|}
\hline Estatística & DBO & DQO & N & P & SST & CLOROFILA & CIANOBACTÉRIAS \\
\hline & Efic (\%) & Efic (\%) & Efic (\%) & Efic (\%) & Efic (\%) & Efic (\%) & Efic (un log) \\
\hline Núm dados & 88 & 122 & 19 & 21 & 34 & 18 & 7 \\
\hline Média & 77 & 65 & 46 & 43 & 69 & 53 & 0,60 \\
\hline Mínimo & 7 & 1 & 11 & 3 & 22 & 4 & 0,14 \\
\hline Máximo & 96 & 90 & 75 & 77 & 98 & 99 & 1,47 \\
\hline Média & 77 & 65 & 46 & 43 & 69 & 53 & 0,60 \\
\hline Mediana & 80 & 67 & 44 & 53 & 67 & 51 & 0,35 \\
\hline Média geométrica & 73 & 61 & 41 & 32 & 66 & 42 & 0,44 \\
\hline Desvio padrão & 17 & 16 & 19 & 24 & 19 & 27 & 0,51 \\
\hline Méd-1 desvpad & 60 & 49 & 27 & 18 & 50 & 25 & 0,09 \\
\hline Méd + 1 desvpad & 94 & 81 & 65 & 67 & 88 & 80 & 1,11 \\
\hline $10 \%$ & 52 & 48 & 23 & 14 & 46 & 18 & 0,20 \\
\hline $25 \%$ & 73 & 59 & 35 & 17 & 56 & 37 & 0,25 \\
\hline $50 \%$ & 80 & 67 & 44 & 53 & 67 & 51 & 0,35 \\
\hline $75 \%$ & 88 & 75 & 60 & 65 & 86 & 74 & 0,87 \\
\hline $90 \%$ & 92 & 81 & 73 & 72 & 91 & 85 & 1,26 \\
\hline
\end{tabular}


ANEXO C - Resultados dos boletins de análises das cianobactérias 


\section{BOLETIM DE ANÁLISES \\ -CIANOBACTÉRIA / CIANOFÍCEA -}

№ da Amostra: 01

Data da Coleta: 07/10/05 Data do Ensaio: 18/02/06

Identificação da Amostra: Lagoas Facultativas (Estabilização) - E.T.E / R.S.L

Ponto de Coleta: Saída das L.F’s (I e II).

Preservação: Formol 4\% Fator de Conversão: 21,93

\begin{tabular}{|c|c|c|}
\hline Descrição (Cianofícea) & № Organismos / $\mathbf{m L}$ & № Células / $\mathbf{~ L ~}$ \\
\hline Planktothrix $s p$ & $1,36 \times 10^{3}$ & $1,64 \times 10^{4}$ \\
\hline Merismopedia $s p$ & 395 & $5,18 \times 10^{3}$ \\
\hline
\end{tabular}

Total de Células de Cianofíceas (Cianobactérias) $=2,16 \times 10^{4}$ Cels $/ \mathrm{mL}$

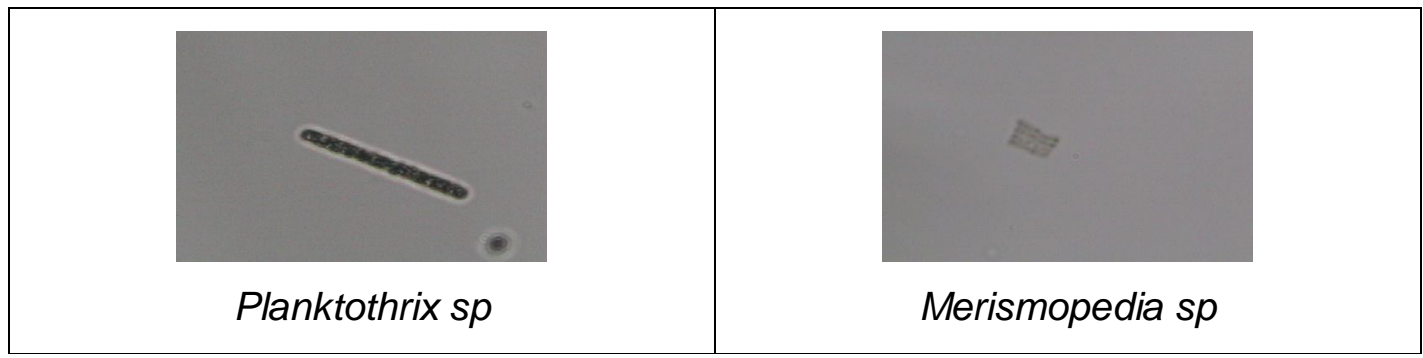

Metodologia:

Conforme Norma Técnica CETESB L5. 303 - Determinação de Fitoplâncton de Água Doce. 


\section{BOLETIM DE ANÁLISES \\ -CIANOBACTÉRIA / CIANOFÍCEA -}

№ da Amostra: 02

Data da Coleta: 07/10/05 Data do Ensaio: 23/05/06

Identificação da Amostra: Efluente Doméstico Tratado - E.T.E / R.S.L

Ponto de Coleta: Despejo do Efluente no Rio

Preservação: Formol 4\% Fator de Conversão: 87,71 Objetiva: 40x

\begin{tabular}{|c|c|}
\hline Descrição (Cianofícea) & № Células / mL \\
\hline Planktothrix sp & 6578 \\
\hline
\end{tabular}

Total de Células de Cianofíceas (Cianobactérias) $=6,58 \times 10^{3}$ Cels $/ \mathrm{mL}$

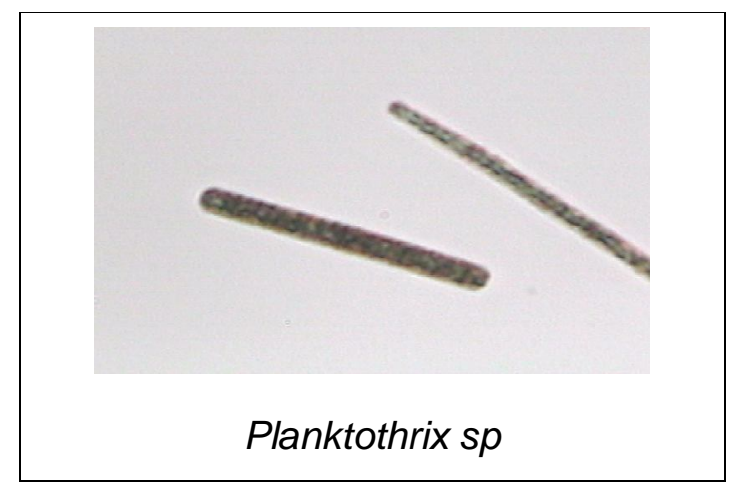

\section{Metodologia:}

Conforme Norma Técnica CETESB L5. 303 - Determinação de Fitoplâncton de Água Doce. 


\section{BOLETIM DE ANÁLISES \\ -CIANOBACTÉRIA / CIANOFÍCEA -}

№ da Amostra: 03

Data da Coleta: 13/10/05 Data do Ensaio: 23/05/06

Identificação da Amostra: Esgoto Doméstico (Lagoas de Estabilização)

Ponto de Coleta: Saída das Lagoas Facultativas (I e III)

Preservação: Formol 4\% Fator de Conversão: 219,29 Objetiva: 40x

\begin{tabular}{|c|c|}
\hline Descrição (Cianofícea) & № Células / mL \\
\hline Planktothrix $s p$ & 26753 \\
\hline Merismopedia $s p$ & 7017 \\
\hline
\end{tabular}

Total de Células de Cianofíceas (Cianobactérias) $=3,38 \times 10^{4}$ Cels $/ \mathrm{mL}$

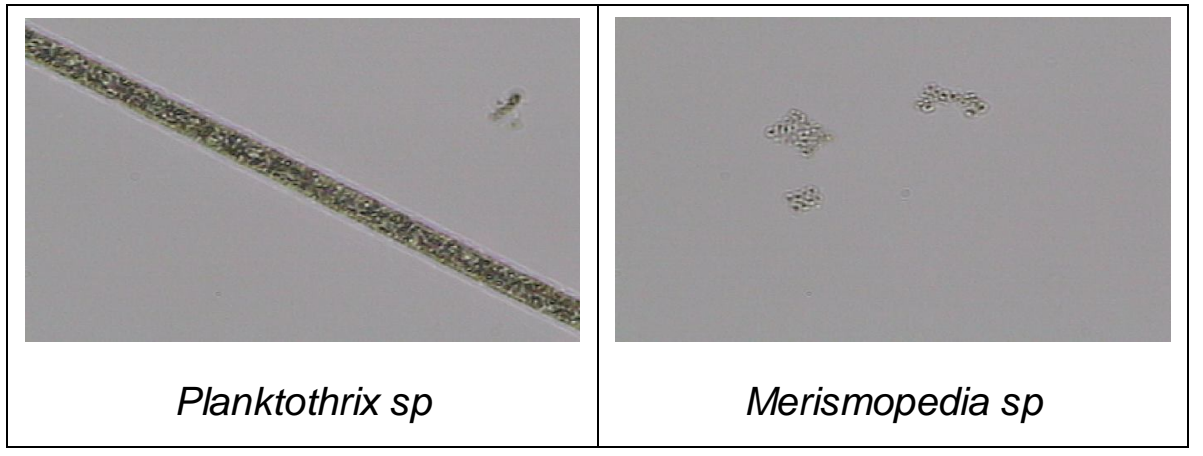

\section{Metodologia:}

Conforme Norma Técnica CETESB L5. 303 - Determinação de Fitoplâncton de Água Doce. 


\section{BOLETIM DE ANÁLISES \\ -CIANOBACTÉRIA / CIANOFÍCEA -}

№ da Amostra: 13

Data da Coleta: 14/11/05 Data do Ensaio: 23/05/06

Identificação da Amostra: Efluente Doméstico Tratado - E.T.E / R.S.L

Ponto de Coleta: Saída do Sistema de Tratamento (após cloração)

Preservação: Formol 4\% Fator de Conversão: $87,71 \quad$ Objetiva: 40x

\begin{tabular}{|c|c|}
\hline $\begin{array}{c}\text { Cianobactérias } \\
\text { (Cianofíceas) }\end{array}$ & № Células $/ \mathbf{m L}$ \\
\hline Planktothrix $s p$ & $6,23 \times 10^{3}$ \\
\hline Microcystis $s p$ & $1,84 \times 10^{3}$ \\
\hline Merismopedia $s p$ & $2,11 \times 10^{3}$ \\
\hline
\end{tabular}

Total de Células de Cianofíceas (Cianobactérias) = 1,02 x 10 Cels $/ \mathrm{mL}$

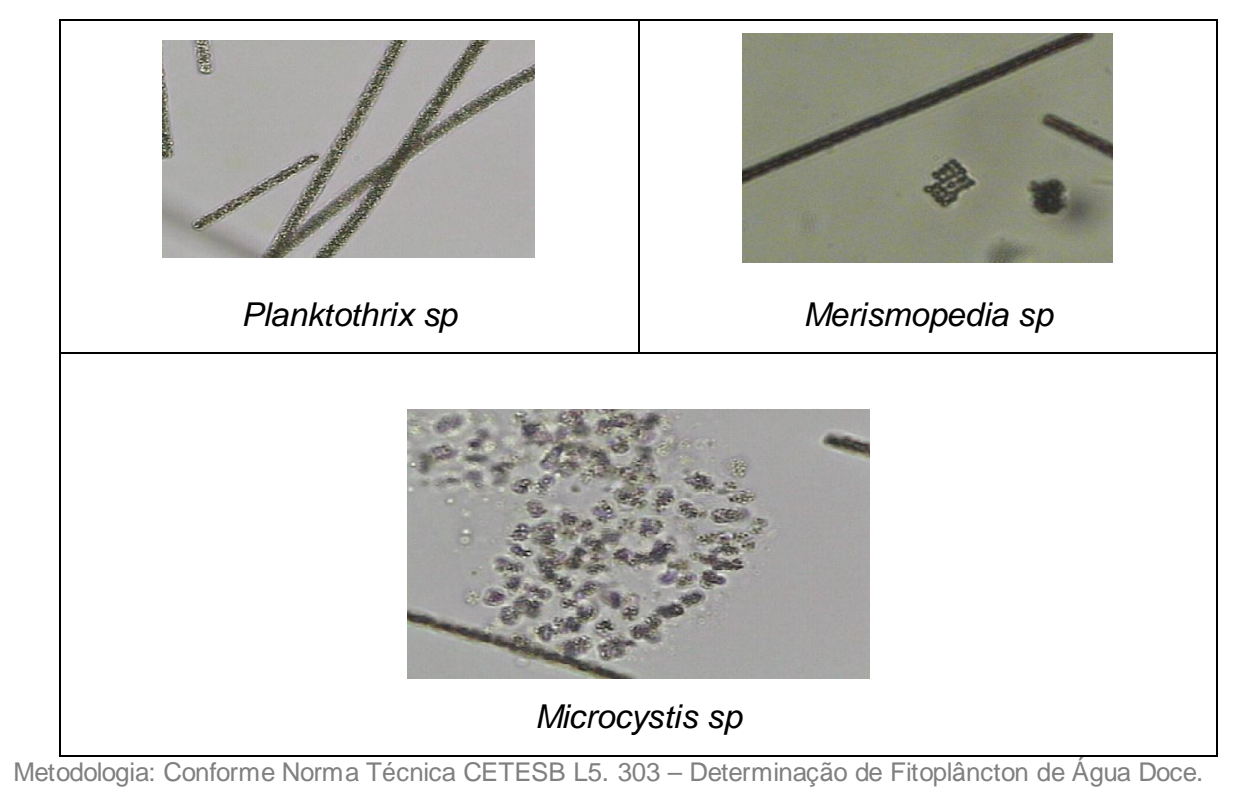




\section{BOLETIM DE ANÁLISES -CIANOBACTÉRIA / CIANOFÍCEA -}

№ da Amostra: 43

Data da Coleta: 16/01/06 Data do Ensaio: 01/06/06

Identificação da Amostra: Esgoto Doméstico - E.T.E / R.S.L

Ponto de Coleta: Saída das Lagoas Facultativas (I e II).

Preservação: Formol 4\% Fator de Conversão: 219,29 Objetiva: 40x

\begin{tabular}{|c|c|}
\hline $\begin{array}{c}\text { Cianobactérias } \\
\text { (Cianofíceas) }\end{array}$ & № Células / mL \\
\hline Planktothrix sp & $4,39 \times 10^{3}$ \\
\hline Merismopedia sp & $1,75 \times 10^{3}$ \\
\hline Chroococcus $s p$ & $4,39 \times 10^{2}$ \\
\hline Pseudanabaena sp & $1,10 \times 10^{3}$ \\
\hline Phormidium $s p$ & $1,36 \times 10^{4}$ \\
\hline
\end{tabular}

Total de Células de Cianofíceas (Cianobactérias) = 2,13 x 10 Cels $/ \mathrm{mL}$

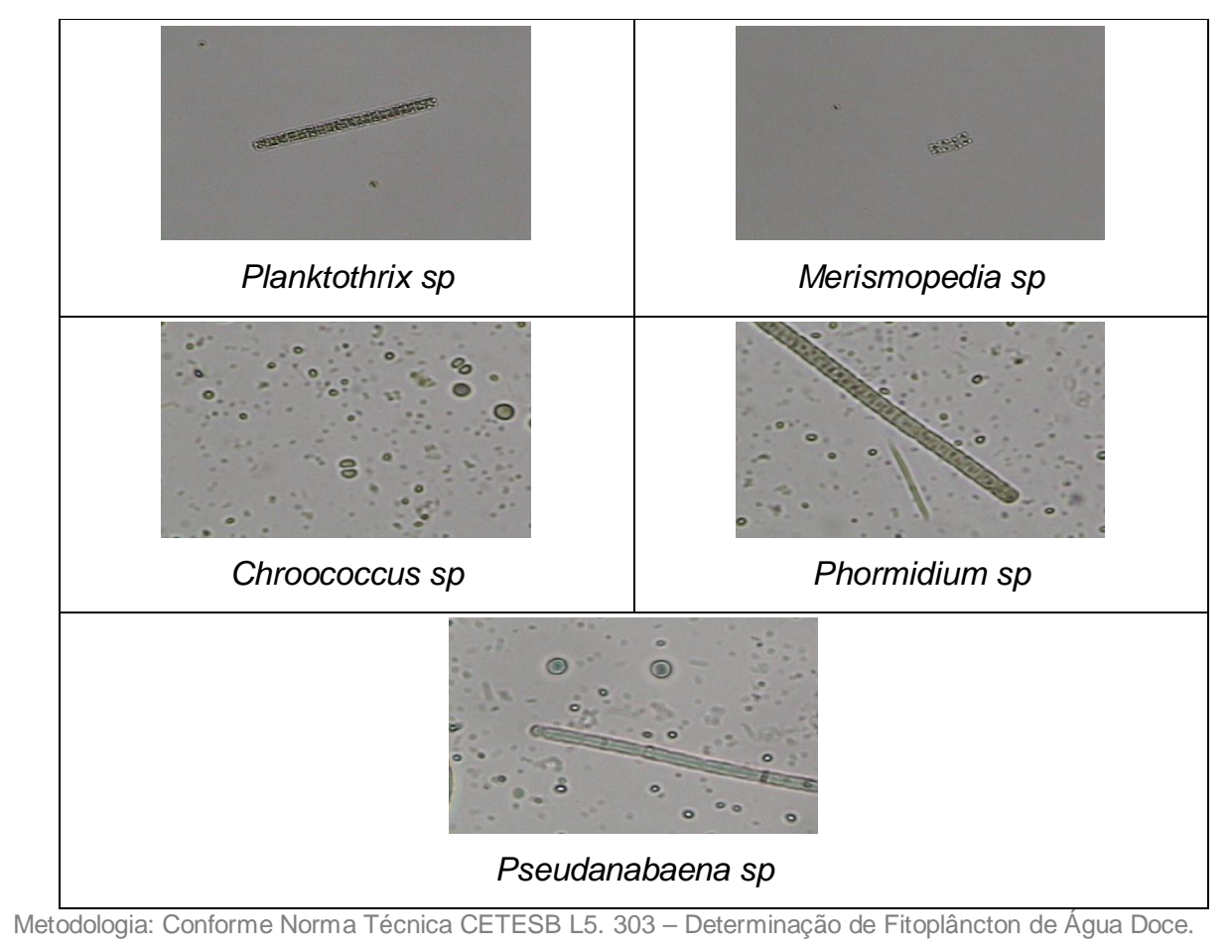




\section{BOLETIM DE ANÁLISES -CIANOBACTÉRIA / CIANOFÍCEA -}

№ da Amostra: 44

Data da Coleta: 16/01/06 Data do Ensaio: 01/06/06

Identificação da Amostra: Esgoto Doméstico - E.T.E / R.S.L

Ponto de Coleta: Saída da Lagoa de Maturação.

Preservação: Formol 4\% Fator de Conversão: 219,29 Objetiva: 40x

\begin{tabular}{|c|c|}
\hline $\begin{array}{c}\text { Cianobactérias } \\
\text { (Cianofíceas) }\end{array}$ & № Células $/ \mathbf{~ m L}$ \\
\hline Planktothrix $s p$ & $4,17 \times 10^{3}$ \\
\hline Merismopedia $s p$ & $3,51 \times 10^{3}$ \\
\hline Chroococcus $s p$ & $1,32 \times 10^{3}$ \\
\hline Pseudanabaena $s p$ & $1,10 \times 10^{3}$ \\
\hline
\end{tabular}

Total de Células de Cianofíceas (Cianobactérias) = 1,01 x 10 Cels $/ \mathrm{mL}$

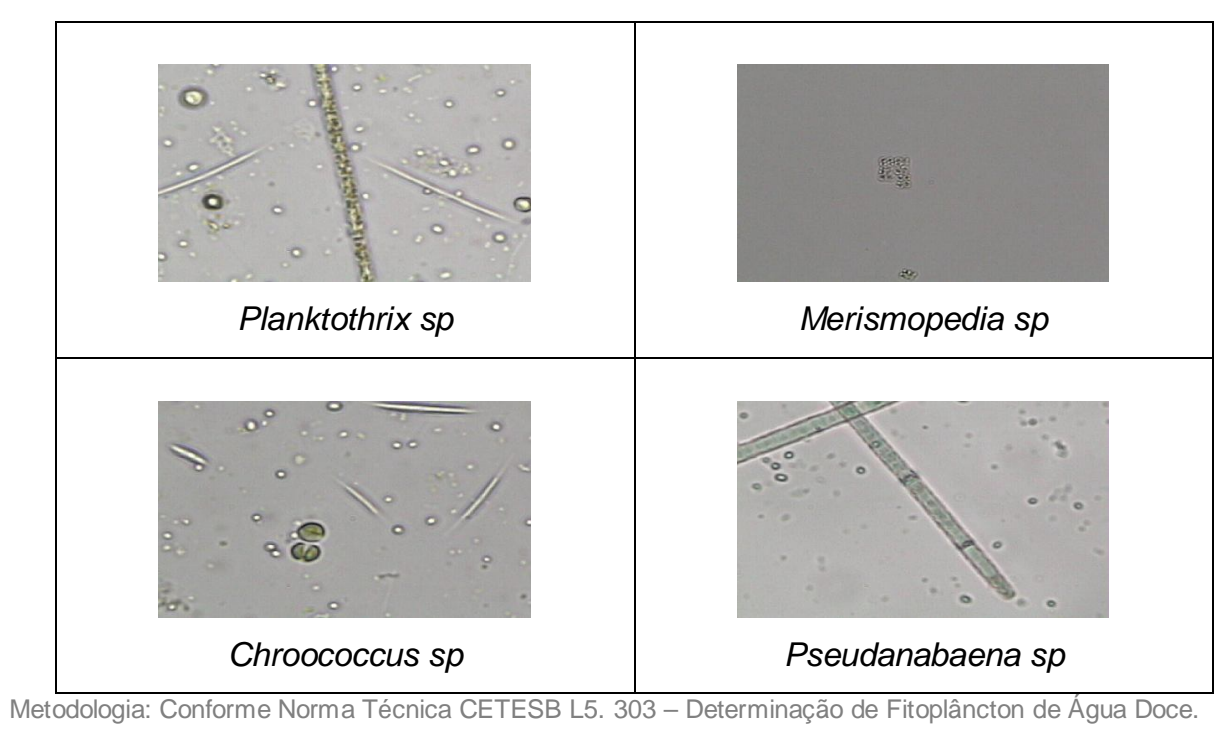




\section{BOLETIM DE ANÁLISES \\ -CIANOBACTÉRIA / CIANOFÍCEA -}

№ da Amostra: 99

Data da Coleta: 06/05/06 Data do Ensaio: 10/06/06

Identificação da Amostra: Esgoto Doméstico - E.T.E / R.S.L

Ponto de Coleta: Saída da Lagoa de Maturação.

Preservação: Formol 4\% Fator de Conversão: $87,71 \quad$ Objetiva: 40x

\begin{tabular}{|c|c|}
\hline $\begin{array}{c}\text { Cianobactérias } \\
\text { (Cianofíceas) }\end{array}$ & № Células $/ \mathbf{m L}$ \\
\hline Planktothrix $s p$ & $9,65 \times 10^{3}$ \\
\hline Merismopedia $s p$ & $1,75 \times 10^{3}$ \\
\hline Aphanocapsa $s p$ & $4,56 \times 10^{3}$ \\
\hline
\end{tabular}

Total de Células de Cianofíceas (Cianobactérias) = 1,60 x 10 Cels $/ \mathrm{mL}$

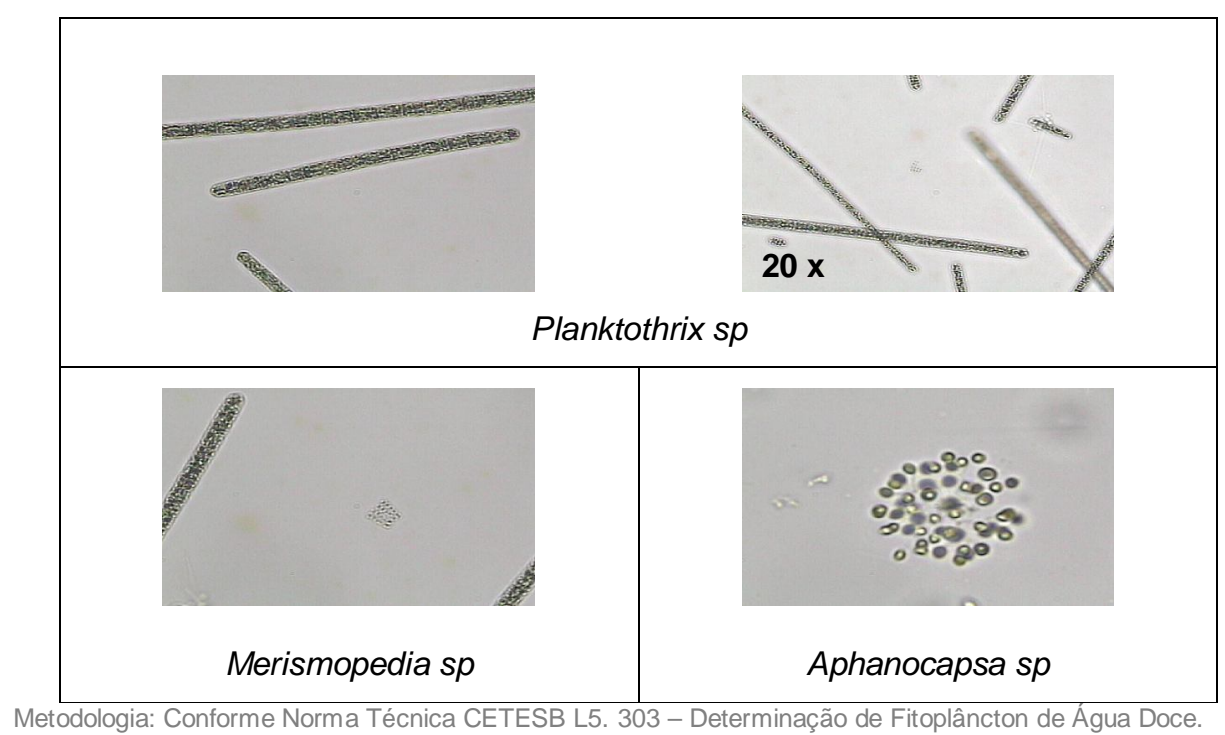

